Institute of Agronomy and Animal Production in the Tropics and Subtropics Georg-August-University Göttingen

\title{
Incidence of Clostridium botulinum Spores in Honey and Infant Food Samples Collected from Vietnam and Germany
}

\author{
Dissertation \\ to obtain the Ph.D. degree in the Faculty of Agricultural Sciences, \\ Georg-August-University Göttingen \\ submitted by \\ Thi Lam An, Vu \\ born in Hanoi, Vietnam
}

Göttingen, November 2006 


\section{7}

Referee: Prof. Dr. Dr. Helge Böhnel

Co-referee: Prof. Dr. Dr. h.c. Udo ter Meulen

Oral examination: 02 November 2006 


\section{Dedication}

to my family with love 


\section{CONTENTS}

Title pages

Page

Contents

Abbreviations

iv

List of tables

viii

List of figures

xii

1 INTRODUCTION

2 REVIEW OF LITERATURE

2.1 C. botulinum

2.1.1 Taxonomy

2.1.2 Growth requirements and cultural characteristics

2.1.3 Properties of $C$. botulinum spores

2.1.4 Bacteriophages, bacteriocins, and plasmids

2.1.5 Botulinum neurotoxins

2.2 Methods of detection, isolation, and quantification

2.2.1 Cultural methods for isolation

2.2.2 Quantification of C. botulinum 13

2.2.3 Cellular fatty acid analysis 13

2.2.4 Detection of neurotoxin by mouse bioassay (MBA) 14

2.2.5 Immunological assays 15

2.2.6 Endopeptidase activity assays 18

2.2.7 Biosensors $\quad 19$

2.2.8 Detection of neurotoxin genes by polymerase chain reaction 20 $(\mathrm{PCR})$ and gene probes

2.3 Botulism in man $\quad 22$

2.3.1 Food-borne botulism 23 
2.3.2 Infant botulism 23

2.3.2.1 Epidemiology 23

2.3.2.2 Clinical spectrum 25

2.3.2.3 Diagnosis 25

2.3.2.4 Treatment 26

2.3.2.5 Prevention 26

2.3.2.6 Link to sudden infant death syndrome (SIDS) 27

2.3.2.7 Risk factors for infant botulism 28

2.3.3 Wound botulism 28

2.3.4 Hidden botulism 28

$\begin{array}{ll}2.3 .5 \text { Inadvertent botulism } & 29\end{array}$

$\begin{array}{ll}3 \text { OBJECTIVES } & 30\end{array}$

4 MATERIALS AND METHODS $\quad 31$

4.1 Bacterial strains and culture conditions 31

4.2 Media 33

4.3 Honey and infant food samples 34

4.4 Spore production $\quad 35$

4.5 Enumeration procedure 38

4.6 Procedures for detection of C. botulinum spores in honey and 38 infant foods

4.7 Preparation of honey and infant food samples 38

4.8 Preparation of spiked honey samples for enumeration of 39 C. botulinum spores

4.9 Preparation of spiked infant food samples for detection of 40 C. botulinum spores

4.10 DNA isolation $\quad 40$

4.11 PCR procedure $\quad 41$

4.12 Mouse bioassay 41 
4.13 Restriction enzyme analysis of PCR products

4.14 Purification of PCR fragments for sequencing 44

4.15 Sequencing analysis 45

4.16 Isolation of $C$. botulinum from PCR-positive samples 45

4.17 Polyacrylamide gel electrophoresis (PAGE) 46

4.18 Statistical analysis $\quad 47$

5 RESULTS $\quad 48$

$\begin{array}{ll}5.1 \text { Spore production } & 48\end{array}$

5.2 Enumeration of $C$. botulinum spores in spiked honey samples 49

5.3 Incidence of $C$. botulinum spores in honey and infant food samples 53

5.3.1 Incidence of $C$. botulinum spores in honey and infant foods 54 purchased in Vietnam

5.3.2 Incidence of $C$. botulinum spores in honey and infant foods 55 purchased in Germany

5.4 Mouse bioassays $\quad 55$

5.5 Isolation of $C$. botulinum from PCR-positive samples 55

5.6 Incidence of $C$. botulinum spores in artificially inoculated honey and 56 infant foods

5.7 Restriction enzyme analysis 58

5.8 Sequence analysis $\quad 58$

6 DISCUSSION $\quad 62$

6.1 Spore production $\quad 62$

6.2 Enumeration of $C$. botulinum spores in spiked honey samples 62

6.3 Incidence of $C$. botulinum spores in honey and infant food samples 64 collected from Vietnam and Germany

6.4 PCR analyses $\quad 67$

$\begin{array}{ll}6.5 \text { Mouse bioassays } & 68\end{array}$ 
6.6 Isolation of C. botulinum from PCR-positive samples 68

6.7 Incidence of C. botulinum spores in artificially inoculated honey and 69 infant foods

6.8 Restriction enzyme analysis $\quad 69$

$\begin{array}{ll}\text { 6.9 DNA sequencing analysis } & 70\end{array}$

7 CONCLUSION $\quad 72$

8 SUMMARY $\quad 74$

8 ZUSAMMENFASSUNG $\quad 76$

9 REFERENCES $\quad 78$

10 APPENDIX 106

$\begin{array}{ll}10.1 \text { Media } & 106\end{array}$

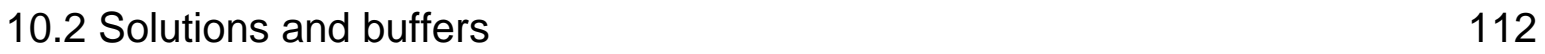

$\begin{array}{ll}\text { 10.3 DNA sequencing analyses } & 115\end{array}$

$\begin{array}{ll}\text { ACKNOWLEDGEMENTS } & 122\end{array}$ 


\section{ABBREVIATIONS}

$\begin{array}{ll}\text { Ab } & \text { antibody } \\ \text { AOAC } & \text { Association of Official Agricultural Chemists } \\ \text { BA } & \text { blood agar } \\ \text { BoNT } & \text { botulinum neurotoxin } \\ \text { CDC } & \text { Centers for Disease Control and Prevention } \\ \text { dATP } & \text { 2'-deoxyadenosine 5'-triphosphate } \\ \text { dCTP } & \text { 2'-deoxycytidine 5'-triphosphate } \\ \text { dGTP } & \text { 2'-deoxyguanosine 5'-triphosphate } \\ \text { DNA } & \text { deoxyribonucleic acid } \\ \text { dNTP } & \text { deoxynucleotide triphosphate } \\ \text { EDTA } & \text { ethylenediaminetetraacetic acid } \\ \text { ELISA } & \text { enzyme-linked immunosorbent assay } \\ \text { EYA } & \text { egg yolk agar } \\ \text { FAAB } & \text { fastidious anaerobe agar with blood } \\ \text { FAAE } & \text { fastidious anaerobe agar with egg yolk } \\ \text { FAB } & \text { fastidious anaerobe broth } \\ \text { FDA } & \text { U.S. Food and Drug Administration } \\ \text { GPB } & \text { gelatine phosphate buffer } \\ \text { HPLC } & \text { high performance liquid chromatography } \\ \text { i.p. } & \text { intraperitoneal injection } \\ \text { i.v. } & \text { intravenous injection } \\ \text { LD } & \text { lethal dose } \\ \text { MAB } & \text { modified Anellis Broth } \\ \text { A } & \end{array}$




\begin{tabular}{|c|c|}
\hline MBA & mouse bioassay \\
\hline MLD & median lethal dose \\
\hline $\mathrm{MLD}_{50}$ & mouse $50 \%$ lethal dose \\
\hline NAPs & neurotoxin associated proteins \\
\hline $\mathrm{NCBI}$ & National Center for Biotechnology Information \\
\hline NCTC & National Collection of Type Cultures \\
\hline PAGE & polyacrylamide gel electrophoresis \\
\hline PBS & phosphate buffered saline \\
\hline PCR & polymerase chain reaction \\
\hline RT-PCR & reverse transcription PCR \\
\hline SE & standard error \\
\hline SeM & Segner Medium modified \\
\hline SIDS & sudden infant death syndrome \\
\hline SM & sporulation medium \\
\hline SNAP-25 & synaptosomal associated protein-25 \\
\hline SNARE & $\begin{array}{l}\text { soluble } \mathrm{N} \text {-ethylmaleimide-sensitive factor attachment protein } \\
\text { receptors }\end{array}$ \\
\hline SSS & salt solution for sporulation \\
\hline TM & trypticase medium \\
\hline TPGYT & trypticase-peptone-glucose-yeast extract broth with trypsin \\
\hline VAMP & vesicle associated membrane protein \\
\hline
\end{tabular}




\section{LIST OF TABLES}

Page

Table 1 Strains versus neurotoxins of $C$. botulinum 5

Table 2 Origin of the $C$. botulinum strains 32

Table 3 Media applied for spore production of C. botulinum 34

Table 4 Types of samples collected from Ho Chi Minh City, Vietnam 35

Table 5 Types of samples purchased in Germany 35

Table 6 Media applied for spore production of different $C$. botulinum strains 37

Table 7 Numbers of $C$. botulinum spores inoculated in honey (spores $\mathrm{g}^{-1} \quad 40$ honey)

Table 8 Primers for PCR detection of $C$. botulinum types A to F 42

Table 9 Restriction enzymes used in the restriction enzyme analyses 44

Table 10 Spore production of the C. botulinum strains in various media 49

Table 11 Recovery of $C$. botulinum in honey samples artificially spiked with 50 individual spore types (MPN g ${ }^{-1}$ )

Table 12 Recovery of C. botulinum in honey samples artificially spiked with 50 mixed spore types (MPN g ${ }^{-1}$ )

Table 13 Recovery of $C$. botulinum types A to $F$ in honey samples inoculated 53 with individual type of spores from different enrichment media $\left(\mathrm{MPN} \mathrm{g}^{-1}\right.$ )

Table 14 Recovery of $C$. botulinum in honey samples spiked with mixed types of spores from different enrichment media (MPN g ${ }^{-1}$ )

Table 15 Incidence of $C$. botulinum spores in honey and infant food samples 54 in Vietnam by PCR

Table 16 Incidence of $C$. botulinum spores in honey and infant food samples 55 in Germany by PCR 
Table 17 C. botulinum isolates from PCR-positive samples 56

Table 18 Nucleotide sequencing analysis of PCR-positive samples 58

Table 19a Sequence identity rate of PCR products of type B samples 115

Table 19b Sequence identity rate of PCR products of type B samples (cont.) 116

Table 20 Sequence identity rate of PCR products of type C samples 117

Table 21 Sequence identity rate of PCR products of type D samples 118

Table 22a Sequence identity rate of PCR products of type E samples 119

Table 22b Sequence identity rate of PCR products of type E samples (cont.) 120

Table 23 Sequence identity rate of PCR products of type F samples 120 


\section{LIST OF FIGURES}

Page

Fig. 1 Comparison of recovery of $C$. botulinum in honey inoculated

51 with individual spore types in different media by PCR

Fig. 2 Comparison of recovery of $C$. botulinum in honey inoculated 52 with mixed spore types in different media by PCR

Fig. 3 Recovery rate of $C$. botulinum spores in inoculated infant 57 foods

Fig. 4 Recovery rate of $C$. botulinum spores in inoculated honey 58

Fig. $5(a, b)$ Digestion patterns of PCR products of type B with Dral 59

Fig. $6(a, b)$ Digestion patterns of PCR products of type C with Mobll 59

Fig. $7 \quad$ Digestion patterns of PCR products of type D with Mobll 60

Fig. $8(a, b)$ Digestion patterns of PCR products of type E with Dral 60

Fig. 9 Digestion patterns of PCR products of type F with Dral

61 


\section{INTRODUCTION}

Botulism is caused by the ingestion of preformed botulinal toxin produced by Clostridium botulinum (C. botulinum), which can grow in improperly preserved foods. It remains the most frequent form in humans worldwide. Recently, infant botulism has been recognised as a different type of toxico-infectious botulism in infants less than 1 year of age (Pickett et al., 1976; Arnon et al., 1979). Epidemiologic and laboratory studies have shown that infants may develop botulism after ingesting $C$. botulinum organisms or their viable spores that subsequently germinate, proliferate in the infant's intestine, and produce botulinal toxin (Midura and Arnon, 1976; Arnon et al., 1977; Arnon et al., 1979; Arnon, 1980; Sakaguchi, 1988). The infection occurs in early infancy because of the immaturity of the microflora of the intestine (Shapiro et al., 1998). Since the first case recognised in 1976, there have been over 1,500 infant botulism cases reported in more than 15 countries worldwide. The youngest baby was just 56 hours of age.

According to statistical data from the Robert-Koch Institute, there is about one case of infant botulism reported each year in Germany. This is probably an underestimated figure due to an inadequate registration of infant botulism cases (Behrens, 1998; Böhnel, 1999). In his personal report, Arnon noted that more than 650 cases were reported from 1976 to 1986 in the United States, and also in other countries throughout the world. In the United States, about $75 \%$ of all botulism cases were infant botulism cases (Shapiro et al., 1998). Between 1982 and 1997, 146 cases of infant botulism were reported in Argentina (Fernández et al., 1999).

C. botulinum is an anaerobic spore-forming organism producing an extremely potent neurotoxin in foods (Lund and Peck, 2000). There are seven types of botulism toxin designated by the letters $A$ through $G$, which are serologically distinct. Types A, B, and $E$ have been reported as the most common causes in humans, while type $F$ is involved in rare cases. The first case of infant botulism due to $C$. botulinum type $C$ was reported in Japan. Most reported cases of infant botulism were caused by type A or B (Arnon, 1980). A few infant botulism cases were associated with $C$. butyricum and $C$. baratii, which produce type $E$ and $F$ 
neurotoxins respectively (Hall et al., 1985; Aureli et al., 1986; McCroskey et al., 1986; Paisley et al., 1995; Fenicia et al., 2002; Barash et al., 2005; Keet et al., 2005).

C. botulinum spores are widespread in soil, dust inside or outside houses, marine sediments, intestinal tracts of animals and fish, animal manure, vegetables, fruits, and honey. Therefore, they are potentially present in a wide range of raw materials used in the food industry, as well as in the environment of food processing factories.

To date, honey has been regarded as the only foodstuff being a significant risk factor for infant botulism (Arnon et al., 1979), although scientific studies have recognised the great medical value of honey. C. botulinum spores have been detected in honey samples in the United States (up to 10\% of the tested samples), Japan (8.5\%), Brazil (7.5\%), and Italy (6.5\%). The contamination levels were estimated at between 5 and 80 C. botulinum spores per gram. About $60 \%$ of infant botulism cases in Europe had a history of honey consumption (Aureli et al., 2002). C. botulinum organisms isolated from five affected patients were of the same toxin type as that found in the honey they were fed (Fenicia et al., 1993; Balslev et al., 1997; Tollofsrud et al., 1998; Monsalve and Alcolea, 1999; Jung and Ottosson, 2001). In a short preliminary study, 20 out of 50 infants of a paediatric clinic in Göttingen, Germany, were infected. However, clinical signs were not recorded (Böhnel, personal communication).

Spore production under laboratory conditions is not always successful. Moreover, spore production of $C$. botulinum faces the difficulty of selecting suitable media to achieve the highest sporulation rates, as well as retaining the toxigenicity of the spores. This is usually required in various fields of research. There are no media that can support sporulation of all strains of this bacterium. Most Probable Number method (MPN), which involves enrichment in a liquid medium and a mouse bioassay (MBA), is frequently used to enumerate $C$. botulinum spores in foods. This method is time consuming and requires experimental animals. The use of the MPN method followed by PCR has been widely investigated with the aim of reducing time consumption and avoiding ethical concerns. 
For detection and identification of botulinal neurotoxins, the only universally recognised method is the mouse toxicity and toxin neutralization bioassay. The use of Polymerase Chain Reaction (PCR) in screening for the presence of botulinal spores in honey samples may shorten detection time, lower the costs, and avoid ethical concerns associated with animal testing.

Detection of the presence and the number of $C$. botulinum spores in honey is necessary. It will give information about the $C$. botulinum spore contamination level of honey, which will decide whether honey is suitable for human consumption. Although it has been reported that the $C$. botulinum spore contamination in honey has no effect on children and adults, the risk of infection is relatively high to infants, to HIV patients, to patients who had taken antibiotics for a long time, or to patients with a history of gastrointestinal surgery. Moreover, the presence of $C$. botulinum spores in honey reflects the $C$. botulinum contamination of the environment because honey is considered an environmental indicator of the $C$. botulinum load.

Although there have been a great number of food poisoning cases in Vietnam recorded annually by its Ministry of Health and Department of Preventive Medicine, there is a lack of information about the incidence of pathogenic bacteria and their toxins in food. With respect to infant botulism, there have been no investigations carried out to survey the presence of $C$. botulinum and its spores in honey and infant foods. Therefore, information related to this disease is insufficient in this country. 


\section{REVIEW OF LITERATURE}

\subsection{C. botulinum}

Belonging to the family Bacillaceae, C. botulinum is an anaerobic, Gram positive, spore-forming soil-borne pathogen that produces a potent biological toxin. C. botulinum comprises a group of culturally distinct bacteria. They are straight to slightly curved, motile rods, 0.5 to $2.0 \mu \mathrm{m}$ in width and 1.6 to $22 \mu \mathrm{m}$ in length, with peritrichous flagella (Cato et al., 1986; Rocke, 1993; ICMSF, 1996). They are natural inhabitants of the soil, marine, and fresh water sediments. They are also found in the intestines of mammalian species such as horses, chickens, companion animals, and humans. The vegetative bacteria are inactivated by chlorine compounds for about $20 \mathrm{~min}$, sunlight for $1-3 \mathrm{~h}$, and heat for $5 \min$ at $85^{\circ} \mathrm{C}$.

\subsubsection{Taxonomy}

C. botulinum strains produce seven neurotoxins that differ antigenically and therefore are differentiated into seven types: A, B, C, D, E, F, or G, named according to their chronological discovery (Sperber, 1982; Kriek and Odendaal, 1994). Based on their physiological characteristics, C. botulinum strains were differentiated into four groups and later confirmed by their phylogenetic relationship (Eklund and Dowell, 1987; Sugiyama, 1988). Group I consists of proteolytic strains of type $A$ and proteolytic strains of type $B$ and $F$. Proteolytic is defined as the ability of bacteria to digest casein in milk, coagulated serum, egg white, and cooked meat. Group II is the non-proteolytic group, including nonproteolytic strains of types B and F, and all strains of type E. Group III includes toxigenic strains of types $C, D$, as well as $C$. novyi type $A$ strains that are culturally quite similar. Group IV consists of type G strains and C. subterminale strains with their similar cultural characteristics. C. argentinense and C. hastiforme are also members of this group (Suen et al., 1988). The relationship of the various clostridial strains was explored by Lawson et al. (1993) using $16 \mathrm{~S}$ rRNA sequencing. A dendogram showing the genealogical interrelationships of 
the strains was established, which demonstrated marked genetic heterogeneity within the genus Clostridium.

Although many $C$. botulinum strains produce a single type of botulinum neurotoxin (BoNT), some strains produce two types of toxin, designated Af (indicating the major and minor toxin produced, respectively), $\mathrm{Ab}, \mathrm{Ba}$, and $\mathrm{Bf}$ (Hauschild, 1990; Franciosa et al., 1994; Cordoba, 1995). Some type C strains produce $\mathrm{C}_{2}$ toxin alone, which is not a neurotoxin, or combinations of dominant $\mathrm{C}_{1}$ and $\mathrm{C}_{2}$ (Eklund et al., 1987). Table 1 shows a summary of the $C$. botulinum strains and their neurotoxins.

Table 1: Strains versus neurotoxins of $C$. botulinum

\begin{tabular}{lc}
\hline Strain & Neurotoxin ${ }^{1,2}$ \\
\hline A & $\mathrm{A}, \mathrm{Ab}, \mathrm{Af}$ \\
$\mathrm{B}$ & $\mathrm{B}, \mathrm{Ba}, \mathrm{Bf}$ \\
$\mathrm{C}$ & $\mathrm{C}_{1},(\mathrm{D})$ \\
$\mathrm{D}$ & $\mathrm{D},\left(\mathrm{C}_{1}\right)$ \\
$\mathrm{E}$ & $\mathrm{E}$ \\
$\mathrm{F}$ & $\mathrm{F}$ \\
$\mathrm{G}$ & $\mathrm{G}$ \\
\hline${ }^{1}$, Capital letter indicates the type of toxin produced in greater \\
amount, while lower case letter indicates the type of toxin produced \\
in lesser amount in some cases.
\end{tabular}

'Non-neurotoxins' $\mathrm{C}_{2}$ and $\mathrm{C}_{3}$ are produced by some strains of $C$. botulinum types (Gunnison and Meyer, 1929; Aktories et al., 1986a; Aktories et al., 1986b). While $\mathrm{C}_{2}$ reacts as cytotoxic enterotoxin (Ohishi and Odagiri, 1984), virulence factors of $\mathrm{C}_{3}$, which is described as an 'exoenzyme', are unclear. Ribosylation effect of $\mathrm{C}_{3}$ on alfalfa plant cells was reported by Minic et al. (1999). A general review of toxic actions on the cellular level was given by Böhnel and Gessler (2005). 


\subsubsection{Growth requirements and cultural characteristics}

In addition to appropriate nutrients, factors that affect the growth of $C$. botulinum in foods are temperature, $\mathrm{pH}$, water activity $\left(\mathrm{a}_{\mathrm{w}}\right)$, redox potential $(\mathrm{Eh})$, food preservatives, and competing microorganisms (CDC, 1998). The nutritional requirements for $C$. botulinum are complex and include several amino acids, growth factors, and mineral salts. The optimal temperature for growth of group I, II, III and IV is $35-40,30,40$, and $37^{\circ} \mathrm{C}$, respectively. However, in case more than one type is detected while only one temperature can be offered, incubation at $30^{\circ} \mathrm{C}$ for 5-7 $\mathrm{d}$ is recommended (Smith and Sugiyama, 1988). According to the Centres for Disease Control and Prevention (CDC, 1998), the growth of $C$. botulinum is inhibited by refrigeration below $4{ }^{\circ} \mathrm{C}, \mathrm{pH}$ below 4.5 , and low water activity. However, holding temperatures below $4{ }^{\circ} \mathrm{C}$ may still allow nonproteolytic strains to grow and produce toxin (Schmidt et al., 1961; Eklund et al., 1967a; Eklund et al., 1967b). Optimal pH for growth of $C$. botulinum is from 7.0-7.2 (Kriek and Odendaal, 1994). Although the lowest $\mathrm{pH}$ for growth of $C$. botulinum is usually accepted at 4.5 , growth under this $\mathrm{pH}$ value was observed by Smelt et al. (1982). A value of $a_{w}$ above 0.93 is required to support growth and toxin production of $C$. botulinum. However, lower $a_{w}$ reduces $C$. botulinum metabolic activity. While the optimal Eh for growth of $C$. botulinum is about -350 $\mathrm{mV}$, toxin production was observed at Eh of $+250 \mathrm{mV}$ (CDC, 1998). Food preservatives such as nitrites, sorbic acids, sorbates, ascorbates, phenolic antioxidants, and polyphosphates inhibit growth and toxin production of $C$. botulinum. The growth of $C$. botulinum may be promoted by microbial flora in certain ecological habitats through molecular oxygen consumption and oxidation-reduction potential lowering (Dezfulian, 1999). Lactic acid producing bacteria such as Lactobacillus, Pediococcus, and Lactococcus may inhibit the growth of C. botulinum (Kim and Foegeding, 1993).

On blood agar, $C$. botulinum strains of various groups form colonies of different shapes, sizes, and characteristics. However, they are usually surrounded by a narrow margin of complete haemolysis, except colonies of group IV strains (Smith and Sugiyama, 1988). Colonies of $C$. botulinum strains of all groups except group IV on egg-yolk agar are covered and surrounded by a thin, pearl layer due to lipase production (Smith and Sugiyama, 1988; Kriek and Odendaal, 
1994). Lecithinase is also formed by some strains of group III (Segner et al., 1971; Smith and Sugiyama, 1988). The distinctive cultural and physiological properties of $C$. botulinum strains of the four groups were described in detail by Hatheway (1993).

C. botulinum can grow and produce toxin in foods under the following conditions: 1) natural or nonprocessed food is contaminated with spores or vegetative cells; 2) processing treatment is inadequate to inactivate $C$. botulinum spores, or the product is re-contaminated after processing (Eklund, 1993); and 3) the food is particularly conductive to create anaerobic conditions that allow $C$. botulinum spores to germinate and outgrow or vegetative cells to grow and produce toxin.

\subsubsection{Properties of C. botulinum spores}

Spores of $C$. botulinum strains of all groups are sub-terminal; those of group I strains swell the vegetative sporangium markedly compared to those of groups II and III strains. C. botulinum spores have the same structure as that of other Clostridium spp. and of Bacillus spp. (Smith and Sugiyama, 1988). They are resistant to heat, light, drying, and radiation. They are inactivated by heating at $121^{\circ} \mathrm{C}$ under 1.0-1.3 KPe for at least $20 \mathrm{~min}$ (ICMSF, 1996). They are readily killed by chlorine, formaldehyde, strong acids, strong bases, and ethylene and propylene oxides. The spore coating with high sulphur content may contribute to the radiation resistance of the spores. The spores have resistance to ultraviolet light, alcohols, phenolic compounds, and organic mercurial compounds. Sporulation temperature, water activity $\left(\mathrm{a}_{\mathrm{w}}\right)$, and $\mathrm{pH}$ of spore or food suspension obviously affect heat resistance of $C$. botulinum spores (Smith and Sugiyama, 1988). C. botulinum spores are widely distributed in soil, in dust, on fresh fruits and vegetables, or in various meats and fish (Ferrari and Weisse, 1995).

The transformation of spores into multiplying vegetative cells consists of three stages: activation, germination, and outgrowth. Heat is often used to activate spores, and recovery media should contain lysozyme (Smith and Sugiyama, 1988). Germination requires neutral $\mathrm{pH}$, temperatures between $15-45^{\circ} \mathrm{C}$, and 
the presence of amino acids and vitamins (Ferrari and Weisse, 1995). Kriek and Odendaal (1994) reported that an addition of $0.1 \%$ of starch promoted germination, because starch binds long chain fatty acids capable of inhibiting spore germination. Outgrowth of spores requires many nutrients and growth conditions that are necessary for vegetative multiplication (Smith and Sugiyama, 1988).

\subsubsection{Bacteriophages, bacteriocins, and plasmids}

Bacteriophage, a large phage with an octahedral head in electron photomicrographs of $C$. botulinum type $C$ cells, was first described by Vinet and his colleagues in 1968. Bacteriophages of types $A$ to $F$ were then examined with an electron microscope by Inoue and lida (1968). It was reported that they were involved in the toxicity of types C (Inoue and lida, 1970; Eklund et al., 1971) and $D$ (Eklund et al., 1972). Toxigenic isolates were recovered from nontoxigenic cultures incubated in broth containing filtrates of the toxigenic strains. Eklund and Poysky (1981) found that toxigenic cultures often lost their toxigenicity when sporulation occurred or when culture medium contained antiserum against the toxigenic phages. The biochemical properties of types $C$ and $\mathrm{D}$ did not change when toxigenic bacteriophages and toxigenicity were lost in media containing antiserum (Oguma et al., 1986). Bacteriophages may convert one type of $C$. botulinum to another and $C$. botulinum type $C$ to culturally similar C. novyi type A (Eklund et al., 1974).

C. botulinum is susceptible to bacteriocins that were divided into three groups. The first group, designated as "boticin P", has a molecular mass of $4 \times 10^{3} \mathrm{kDa}$ and acts on non-proteolytic types $B$ and $F$ and all strains of type $E$. It is produced by a non-toxigenic strain of $C$. botulinum type E, PM-15 (Lau et al., 1974). It does not inhibit germination and outgrowth of $C$. botulinum spores. The second group, called "boticin E", is produced by some non-toxigenic clostridia whose biochemical properties and morphological characteristics are similar to C. botulinum type $\mathrm{E}$. This group includes two distinct boticins: a small form with a molecular mass $<30 \mathrm{kDa}$ and a large form with a molecular mass $>40 \mathrm{kDa}$ (Ellison and Kautter, 1970). These boticins are bacteriolytic for vegetative cells 
and bacteriostatic for spores of C. botulinum type E strains (Kautter et al., 1966). The third group is the antibiotic-like bacteriocin produced by a strain of Moraxella spp. (Kwan and Lee, 1974). It affects the outgrowth of type E spores, but does not affect their germination.

Plasmids, or free cyclic DNA molecules that are capable of autonomous replication, were found in a toxigenic type $A$, a toxigenic type $E$, and several non-toxigenic strains (Scott and Duncan, 1978). Strom et al. (1984) indicated that plasmid carriage is widespread in C. botulinum and related species. The plasmids were not responsible for any special characteristics of the bacteria carrying them, except for a plasmid carried by type $G$ strains that is responsible for toxin production (Eklund et al., 1988).

\subsubsection{Botulinum neurotoxins}

Botulinum neurotoxin (BoNT) is the most potent lethal toxin known (Lamanna, 1959; Gill, 1982). Compared to sarin, a potent organophosphate nerve agent, it is 15,000 to 100,000 times more toxic. The lethal dose (LD) of the toxin for man is estimated at $1 \mathrm{ng} \mathrm{kg}^{-1}$ (Bonventre, 1979). Approximately for a 70-kg man, lethal dose of crystalline type A would be only $70 \mu \mathrm{g}$ orally, 0.09-0.15 $\mu \mathrm{g}$ intravenously, and 0.7-0.9 $\mathrm{\mu g}$ inhalationally (Schantz and Johnson, 1992). A single gram of crystalline toxin that is evenly dispersed and inhaled would kill more than 1 million people, although technical factors would make such dissemination difficult (Arnon et al., 2001). The median lethal dose (MLD) per gram of body mass of the toxin type $A, B, C_{1}, D, E$, and $F$ for mice is 1.2 ng i.p. (intraperitoneal injection), 0.5-2 ng i.p., $1.1 \mathrm{ng}$ i.v. (intravenous injection), $0.4 \mathrm{ng}$ i.p., $1.1 \mathrm{ng}$ i.p., and $2.5 \mathrm{ng}$ i.v., respectively (Gill, 1982). The MLD of botulinum toxin type C for cattle, according to Moeller and David (2003), is 0.25-2.5 ng per kilogram of body mass.

BoNTs of all types, designated A through $\mathrm{G}$, have similar pharmacologic actions. However, they are serologically distinct and are distinguished by neutralisation of biological activity with serologically type-specific antibodies. Exceptionally, some toxins have the same antigen characteristics: $\mathrm{C}_{1}$ and $\mathrm{D}$ toxins (Oguma et al., 1984) and $E$ and $F$ toxins (Kozaki et al., 1986), which may 
result in a cross reaction in serologic tests. Several subserotypes that are immunologically distinguishable within a serotype have been reported. Two subtypes of serotype $A$ were identified by restriction mapping and DNA sequencing, designated A1 and A2 (Cordoba et al., 1995). These two subtypes exhibit amino acid identity of 89\% (Willems et al., 1993).

BoNTs are produced intracellularly by the bacteria and released during autolysis of the bacterial cells. They are initially synthesised as an inactive form, a single-chain polypeptide with a molecular mass of about $150 \mathrm{kDa}$, which is activated by bacterial or tissue proteases (or trypsin) following bacterial lysis. The activated protein consists of a heavy $(\mathrm{H})$ chain $(100 \mathrm{kDa})$ and a light $(\mathrm{L})$ chain (50 kDa), which are linked by a single disulfide bond (Goonetilleke and Harris, 2004).

While $C$. botulinum spores are heat resistant, the neurotoxin is heat-labile. Heating at $85^{\circ} \mathrm{C}$ for at least 5 min destroys the toxin (ICMSF, 1996). It has been reported that boiling food to ensure thorough heating of the interior will destroy the toxin.

BoNTs are zinc-dependent endopeptidases targeting various specific proteins: type $A$ and $E$ target SNAP-25, a protein of the presynaptic membrane; type C targets SNAP-25 and syntaxin, an integral membrane protein that is involved in membrane fusion; and types B, D, F, and G target VAMP (synaptobrevin), a protein of the neurotransmitter-containing vesicles. However, the hydrolysis of the target protein, blockade of transmitter release, and the resultant flaccid paralysis are the same final result of these toxins' actions (Schiavo et al., 1992; Goonetilleke and Harris, 2004). With the hypothesis about interference in the neurological control of intestinal physiology caused by long-lasting absorption of low quantities of botulinum toxin, Böhnel and colleagues (2001b) proposed the name 'visceral botulism' to describe the chronic form of botulism in cattle. Binding sites of botulinum toxin in the central nervous system, especially in the hippocampus, cerebellum, as well as in the cerebral cortex have also been described (Black and Dolly, 1987; Simpson, 1989; Li and Singh, 1998; Böhnel and Gessler, 2005). 
The toxins are absorbed from the gastrointestinal $(\mathrm{Gl})$ tract into the circulation. They spread to all parts of the body except the central nervous system as they cannot penetrate the blood-brain barrier. However, apparently the only sites for which they have significant affinity are peripheral cholinergic nerve endings. They interfere with the release of acetylcholine from cholinergic neurons of the neuromuscular junction and autonomic synapses. The blockade of acetylcholine activity results in a flaccid paralysis and imbalances in the autonomic nervous system (Montecucco and Schiavo, 1994; Rossetto et al., 1995; Simpson et al., 1999).

Types $A, B$, and $E$ toxins are most frequently implicated in human botulism (Lamanna, 1959; Simpson, 1999), while type $C_{1}$ and $D$ toxins mainly cause the disease in domestic animals and birds and type B toxin affects cattle and horses (Swerczek, 1980; Barsanti, 1990; Hatheway, 1995). C. botulinum type C outbreaks in human are extremely rare (Segner et al., 1971). The human gastrointestinal tract does not have receptors for botulinum neurotoxin for translocation into the circulation (Maksymowych and Simpson, 1998). Dogs are most often affected by type $C_{1}$ botulinum toxin (Barsanti et al., 1978; Barsanti, 1990).

\subsection{Methods of detection, isolation, and quantification}

Detection and isolation of $C$. botulinum are difficult. There are no selective media available for culturing both proteolytic and non-proteolytic $C$. botulinum. The detection of the microorganism in the environment and in foods and their raw materials is complicated because of the presence of abundant spores and/or indemonstrable toxins (Hyytia et al., 1999).

The isolation of $C$. botulinum in the environment and food samples is subject to various limitations due to the presence of non-toxigenic strains. These phenotypically and genotypically resemble C. botulinum (Lee and Riemann, 1970; Lindström et al., 2001). Moreover, no single procedure, medium, or temperature is best for the incubation of all toxin types and cultural varieties of the microorganism (Smith and Sugiyama, 1988). 


\subsubsection{Cultural methods for isolation}

The cultivation of $C$. botulinum requires strict anaerobic techniques and incubation. Different conditions are required for the isolation of proteolytic and non-proteolytic $C$. botulinum because they are physiologically distinct. Heat treatment is frequently used to eliminate competing vegetative bacteria and activate dormant spores to germinate. While heating at $75^{\circ} \mathrm{C}$ to $80^{\circ} \mathrm{C}$ for 10 to $15 \mathrm{~min}$ is useful in culturing spores of proteolytic $C$. botulinum, a lower temperature, e.g. $60^{\circ} \mathrm{C}$ for 15 to $30 \mathrm{~min}$ or $71^{\circ} \mathrm{C}$ for $15 \mathrm{~min}$, is used in isolation of non-proteolytic strains and group III strains, respectively (Segner et al., 1971). Alternatively, ethanol treatment is used for isolation of spores of nonproteolytic $C$. botulinum to eliminate non-spore formers that can compete with the target microorganism and adversely affect its growth (CDC, 1998).

However, using heat and alcohol treatment may fail to isolate vegetative bacteria (Dezfulian et al., 1981) and toxigenic strains may become nontoxigenic (Eklund and Poysky, 1972). For isolation of vegetative cells or spores that are not fully heat resistant, the heat treatment is not required.

Enrichment of $C$. botulinum must be carried out under anaerobic conditions (Hatheway, 1988; Kautter et al., 1992; Solomon and Lilly, 2001). Cooked Meat Medium (CMM) incubated at $35{ }^{\circ} \mathrm{C}$ should be used to enrich proteolytic $C$. botulinum, while for non-proteolytic $C$. botulinum CMM fortified with glucose, chopped meat glucose starch medium, or trypticase-peptone-glucose-yeast extract broth containing trypsin (TPGYT) may be used and incubated at $26{ }^{\circ} \mathrm{C}$ (Hauschild, 1989). Lysozyme $\left(5 \mu \mathrm{g} \mathrm{mL}^{-1}\right)$ was recommended to add to enrichment medium to stimulate germination of $C$. botulinum spores (Smith and Sugiyama, 1988). An addition of $0.1 \%$ starch may promote the germination (Kriek and Odendaal, 1994). It was recommended to add trypsin to an enrichment medium, except for medium containing cooked meat particles, to inactivate bacteriocins inhibitory to $C$. botulinum. Cooked meat particles reduce rapidly the proteolytic activity of the trypsin (Smith and Sugiyama, 1988). It was reported that enrichment cultures should be incubated for 5-7 $d$, or even longer, to allow growth, botulinum toxin formation and sporulation (Smith and Sugiyama, 1988; Broussolle et al., 2002). 
After the enrichment, the culture can be used for detecting neurotoxins by mice injection and plating on solid media. Egg-yolk agar is a suitable non-selective medium because on this agar, strains of both group I and group II have colony appearance associated with their lipase activity (Smith and Sugiyama, 1988; Lund and Peck, 2000). C. botulinum Isolation (CBI) agar (Dezfulian et al., 1981) and Botulinum Selective Medium (BSM) (Mills et al., 1985) have been used for selective detection of proteolytic strains. Non-proteolytic strains are inhibited by trimethoprin in these media. Colonies that are suspected to be C. botulinum are used for further analyses and identification.

\subsubsection{Quantification of C. botulinum}

Enumeration of $C$. botulinum was conventionally performed by using a pourplate procedure (Hauschild and Hilsheimer, 1977; Glasby and Hatheway, 1985) or the most probable number method (MPN) combined with MBA or PCR (Hielm et al., 1996). Recently, real-time PCR, which is based on the quantification of specific amplified DNA, has been applied for the quantitative detection of $C$. botulinum type A (Yoon et al., 2005) and type $E$ (Kimura et al., 2001) in food and of Clostridium sp. in faeces of autistic children (Song et al., 2004). Competitive reverse transcription-PCR (RT-PCR) was developed for enumerating non-proteolytic type $E$, which accurately measures the level of toxin-encoding mRNA in C. botulinum cells (McGrath et al., 2000).

\subsubsection{Cellular fatty acid analysis}

Based on fatty acids produced by different types of $C$. botulinum, cellular fatty acid analysis by gas liquid chromatography (GLC) has been applied to differentiate C. botulinum types (Reiner and Bayer, 1978; Gutteridge et al., 1980; Ghanem et al., 1991). By means of gas chromatography (GC), Rieke (1981) could differentiate clostridia strains based on analysis of acetic acids, propanoic acids, iso-butyric acids, and iso-valeric acids. Ghanem et al. (1991) found that several toxin types of $C$. botulinum and their non-toxic counterparts could be differentiated so well by their cellular fatty acid compositions, 
especially in view of the phenotypic and genetic similarities (at the species level). One limitation of this technique is that toxin types of bacteria in the same group could not be separated from each other or from those of related species (Heitefuß, 1991).

\subsubsection{Detection of neurotoxin by mouse bioassay}

Intraperitoneal injection into mice called mouse bioassay (MBA) has been used as the standard method for detection and identification of botulinum toxins (Schantz and Kautter, 1978; Smith and Sugiyama, 1988; CDC, 1998). Trypsin treatment is required for neurotoxin detection of types $B, C, D, E$, and $F$ if the culture medium does not contain trypsin (Smith and Sugiyama, 1988).

Trypsinisation activates the toxins by converting the single chain toxin to the more toxic dichain form (Lund and Peck, 2000). It is recommended to use two mice for a test (Smith and Sugiyama, 1988; CDC, 1998). However, due to ethical reasons one mouse can be used for a test (Sandler et al., 1993).

Typical symptoms of botulism in mice begin with ruffling of the fur, followed by laboured abdominal breathing, wasp-like narrowed waist, weakness of limbs, paralysis, and respiratory failure resulting in death (Smith and Sugiyama, 1988; CDC, 1998). The specificity of MBA is based on the use of specific antisera and the observation of the typical symptoms.

Toxin neutralisation test, also called mouse protection test, has been used for identifying presence of toxic botulism bacteria. The toxin-antitoxin mixtures are injected i.p. into mice that will be observed for four days. The antitoxin type that protects the mice reflects the toxin type in tested samples (Smith and Sugiyama, 1988; CDC, 1998). Monovalent types or polyvalent of neurotoxins can be used in neutralisation tests (CDC, 1998). However, false-positive results due to cross reactions between botulinum and tetanus toxins were reported by Dolimbek et al. (2002) and Saeed (2005).

Although the biological tests are sensitive and may detect previously undiscovered botulinum neurotoxins, atypical toxins, and antigenic variants, they are time consuming, expensive, complicated, and are not suitable for 
examining samples containing other lethal substances or very low levels of toxin. Such tests using animals are increasingly restricted due to ethical concerns (Dezfulian and Bartlett, 1985a). Cross reactions were reported between C. botulinum types C and D (Jansen, 1971; Fach et al., 1996) and between types $E$ and $F$ (Yang and Sugiyama, 1975). Clinical cases of botulism failed to be detected or inconclusive results were reported in some studies in which MBA was applied (Thomas, 1991; Trueman et al., 1992; Szabo et al., 1994b; Böhnel, 1999). Diagnostic methods of C. botulinum and its toxin are still insufficient and poorly developed (Gessler and Böhnel, 2003; Robinson and Nahata, 2003).

Mouse diaphragm assay (MDA) is currently used to detect antibodies against BoNT (BoNT-Ab). It measures BoNT-Ab induced blockade of the paralysing effect of BoNT on a mouse hemidiaphragm preparation (Dressler and Dirnberger, 2001). Dressler et al. (2005) applied this assay to detect antibodies against botulinum toxin type $B$ (BoNT-B-Ab). The detectable concentration of BoNT-B-Ab was $0.4 \mathrm{mU} \mathrm{mL}^{-1}$.

\subsubsection{Immunological assays}

Immunological methods like enzyme-linked immunosorbent assays (ELISAs) and other techniques have been used widely to detect toxins (Notermans et al., 1982b; Ferreira et al., 1990; Carlin and Peck, 1996) and to identify colonies of C. botulinum (Dezfulian and Bartlett, 1985b; Goodnough et al., 1993). These methods also have been used to detect $C$. botulinum neurotoxins in clinical and food specimens (Shone et al., 1985; Potter et al., 1993; Rocke et al., 1998; Poli et al., 2002; Ferreira, 2003; Ferreira et al., 2004).

Low sensitivity or specificity of immunological methods was noted in assays such as passive haemagglutination assay (Evancho et al., 1973), radioimmunoassay (Boroff and Shu-Chen, 1973), and immunodiffussion assay (Ferreira et al., 1981). ELISAs have been modified to improve their sensitivity and specificity, for instance, amplified immunoassay ELISA-ELCA (Roman et al., 1994), colorimetric capture ELISAs (Szilagyi et al., 2000; Poli et al., 2002), magnetic-bead ELISA (Kourilov and Steinitz, 2002; Gessler and Böhnel, 2006), 
immunoaffinity column assays (Gessler et al., 2005), and amplified enzymelinked immunosorbent assay (Ferreira, 2003).

To achieve a higher sensitivity with immunological methods used for detection of $C$. botulinum, immuno-PCR methods have been developed in which a specific DNA molecule is used as label (Sano et al., 1992; Wu et al., 2001). The sensitivity of the antigen detection by immuno-PCR was enhanced from 100fold (Joerger et al., 1995; Wu et al., 2001) to 100,000-fold (Sano et al., 1992) in comparison to that of conventional ELISA.

The sensitivity and specificity of some of the ELISAs are similar to that of the mouse bioassay, (Doellgast et al., 1993; Doellgast et al., 1994; Ferreira, 2003) or even more sensitive (Roman et al., 1994; Hanna et al., 1999). These techniques are recommended for use as an alternative to mouse bioassay to save time and avoid using animals in vivo toxicity tests.

However, applying ELISAs have limitations. Many ELISAs require complex and expensive applications (Shone et al., 1985; Doellgast et al., 1993). Some may react with biological inactive toxin (Huhtanen et al., 1992) and cross react with other clostridia (Fernandez and Peck, 1997). Depending on the type examined and the culture media used, false positive results from 1.5 to $28.6 \%$ of samples due to the cross reaction with other toxin types were reported by Gessler and Böhnel (2003). Cross reactions were observed between types A and B by Dezfulian et al. (1984), between types $C_{1}$ and $D$ by Notermans and his coworkers (1982a), and between types $C$ and $D$ and C. novyi type $A$ (Thomas, 1991). Commercial ELISAs are limited to pathogenic botulinum neurotoxin types A, B, and E for humans (Gessler and Böhnel, 2003).

Immunochromatographic assays are a logical extension of the technology used in latex agglutination tests. The first assays were developed in 1956 by Singer and Plotz. These assays utilise antigen-antibody reaction on a nitrocellulose membrane where a colour band from attached gold beads indicates the antigen-antibody reaction. This principle is identical to the widely accepted "Pregnancy test" technology.

Chiao and colleagues (2004) developed an immunochromatographic assay, the colloidal gold-based immunochromatographic assay. This essay was designed 
to detect botulinum neurotoxin type $B$ based on the sandwich format using polyclonal antibodies. In less than 10 min, botulinum neurotoxin type $B$ was detected at concentrations of $50 \mathrm{ng} \mathrm{mL}^{-1}$. The treatment of test strips with silver enhancer can increase the assay sensitivity to $50 \mathrm{pg} \mathrm{mL}^{-1}$. No cross reaction to type $A$ and $E$ neurotoxins occurred.

The lateral-flow assays developed by the Naval Medical Research Centre (Silver Spring, MD) and Alexeter Technologies (Gaithersburg, MD) for detection of botulinum neurotoxin types A, B, and E in liquid, solid, and high-fat-content foods were evaluated by Shamar et al. (2005). The detectable concentration was $10 \mathrm{ng} \mathrm{mL}^{-1}$ for types $A$ and $B$, and $20 \mathrm{ng} \mathrm{mL}^{-1}$ for type $\mathrm{E}$. Although these assays were found less sensitive in comparison to other in vitro detection methods, and the result assessment is strictly qualitative, they are rapid, user friendly, long-term stable, and relatively inexpensive.

The biowarefare agent detection devices (BADD) were developed by Osborn Scientific Group. They are easy-to-use test sets performing an in vitro immunochromatographic assay capable of qualitatively detecting the presence of specific biological warfare agents. The botulinum toxin test set (BOT-E500-4, USA) is used to examine swab samples from contaminated surfaces or liquid materials. This test set can detect botulinum neurotoxin types $A$ to $G$ in concentrations of $50 \mathrm{ng}$ or greater on a hard, smooth surface, or $100 \mathrm{ng} \mathrm{mL}^{-1}$ in solution within $15 \mathrm{~min}$. However, the test set cannot specify which types of neurotoxin are present in the test samples. Moreover, the test results cannot be observed $15 \mathrm{~min}$ after the test has been done because colour signals will be no longer observable.

The flow through and lateral flow immunochromatographic assays for detection of botulium neurotoxin type D were developed by Klewitz (2005). The formation of a "mobile sandwich complex" was optimised with an effective sample pretreatment. An enzymatic staining reaction was used in the flow through immunochromatographic assay for the detection of the immobilised sandwich complex within $6 \mathrm{~h}$. It had a test sensitivity of $50 \mathrm{pg} \mathrm{mL}^{-1}$. Other flow through assays where gold conjugated antibodies were used decreased the test sensitivity, i.e. $50 \mathrm{ng} \mathrm{mL}^{-1}$. In the lateral flow assay, colloidal gold particles were used as a labelling reagent. The minimum detectable concentration of 
botulinum neurotoxin type $D$ was $50 \mathrm{pg} \mathrm{mL}^{-1}$ within less than $5 \mathrm{~h}$.

According to manufacturers, theses assays are recommended for initial screening of environmental and food samples.

\subsubsection{Endopeptidase activity assays}

Another approach to the botulinum toxin detection is based on its endopeptidase activity. Highly specific antibody-enzyme reagents are used to monitor and detect the cleavage of immobilised peptide substrates by botulinum toxin (Schmidt and Bostian, 1995; Ekong et al., 1997a; Ekong et al., 1997b; Wictome et al., 1999). These methods have several advantages over ELISA procedures (Lund and Peck, 2000). These in vitro assays may directly measure the biological activity of the light chain because the cleavage reaction is highly specific. Therefore, false negatives are rare.

There are several types of endopeptidase activity assays for measurement of botulinum neurotoxin types $A$ and $B$ : the high pressure liquid chromatography (HPLC) based methods (Schmidt and Bostian, 1995; Ekong et al., 1997b) and the methods using a combination of endopeptidase activity and immunological reactions (Hallis, 1996; Ekong et al., 1997a). The HPLC methods have disadvantages because they are less sensitive than the MBA and are not suitable for the rapid detection of toxin in large numbers of samples. The latter methods were type specific and did not cross react with other botulinum neurotoxins (Hallis, 1996) and were more sensitive than MBA (Ekong et al., 1997b; Wictome et al., 1999). Another assay, a rapid, mass spectrometry-based method was developed by Barr et al. (2005). Botulinum neurotoxin types A, B, $\mathrm{E}$, and $\mathrm{F}$ at concentrations of $0.62 \mathrm{MLD}_{50} \mathrm{~mL}^{-1}$ were detected by matrix-assisted laser-desorption ionisation time-of-light mass spectrometry (MALDI-TOF-MS). All seven neurotoxin types in a multiplexed assay format were detected by MALDI-TOF-MS with no cross-reactions and the detection limits from 0.039 to $0.625 \mathrm{MLD}_{50} \mathrm{~mL}^{-1}$ (Boyer et al., 2005). 


\subsubsection{Biosensors}

Recently, biosensors have been developed and widely applied to examine a variety of potentially threatening biological and chemical substances. This approach is also seen in botulinum toxin research.

Fibre-optical biosensors were developed for the quantitative detection of botulinum toxin. Type $A$ toxin at concentrations of as low as $5 \mathrm{ng} \mathrm{mL}^{-1}$ is detected by using evanescent wave technology within a minute. Rhodaminelabelled polyclonal antitoxin A immunoglobin $\mathrm{G}(\mathrm{lgG})$ antibodies were used as a sandwich immunoassay for generation of the specific fluorescent signal. The technique was found to be highly specific, and no response was observed against tetanus toxin (Ogert et al., 1992). Kumar et al. (1994) also used an evanescent wave immunosensor for a quantitative analysis of bound botulinum neurotoxin and quartz fibre-immobilised antibody (FiAb) by Dot-Blot analysis using avidin-horseradish peroxidase (HRP) conjugate.

The array biosensor developed by Ligler et al. (2003) was capable of rapidly detecting the simultaneous toxic compounds of staphylococcal enterotoxin $B$, ricin, cholera toxin, botulinum toxoids $A$ and $B$, trinitrotoluene, and the mycotoxin fumonisin at levels as low as $0.5 \mathrm{ng} \mathrm{mL}^{-1}$. Sandwich and competitive fluoroimmunoassays were developed to detect high and low molecular mass toxins in environmental and food samples and clinical fluids, with minimal sample preparation. A mechanosensor was developed by Liu et al. (2003). This technique relied on the detection of an agarose bead detachment from the tip of a micromachined cantilever. The cantilever action is dependent on botulinum neurotoxin type $B$ acting on its synaptic protein. This substratum called synaptobrevin 2 was attached to the beads. Within 15 minutes, type $B$ neurotoxin at concentrations of $8 \mathrm{nM}$ could be detected.

Another approach to detecting botulinum neurotoxin is by using a biosensor based on gangliosides, i.e., natural cellular receptors for the toxin. This occurs when they are incorporated onto a liposome surface. Liposomes containing gangliosides mimic cells that are invaded by bacterial toxins and can be used as sensitive probes for detecting these toxins. The fluorescent liposomes, containing both a marker (rhodamine) and a receptor (GT1b or GM1) in a 
bilayer, were used in sandwich fluoroimmunoassays for tetanus, botulinum, and cholera toxins at levels as low as $1 \mathrm{nM}$ of each toxin (Singh et al., 2000). A similar receptor immunoassay for botulinum toxin using gangliosideincorporated liposomes was applied by Ahn-Yoon et al. (2004). In this assay, GT1b gangliosides were incorporated into the surface of dye encapsulated liposomes. Botulinum toxin bound to the GT1b-liposomes was captured by antibotulinum toxin antibodies immobilised in a band on a nitro-cellulose membrane strip. The intensity of the coloured band was visually estimated, or measured by densitometry using computer software. The sandwich assay using GT1bliposomes for detection of botulinum toxin within less than 20 min was found to be rapid and very sensitive. The threshold of toxin detection was determined to be as low as $15 \mathrm{pg} \mathrm{mL}^{-1}$. It was suggested that the assay could be used for detecting botulinum toxin in field screening, simply and reliably, without the need for complex instrumentation.

\subsubsection{Detection of neurotoxin genes by polymerase chain reaction (PCR) and gene probes}

With their high sensitivity and specificity, molecular biological techniques have been developed for the non-specific detection of genes for all types of botulinum neurotoxins (Campbell et al., 1993) and for the specific detection of genes for each neurotoxin type (Szabo et al., 1993; Franciosa et al., 1994; Fach et al., 1993; Fach et al., 1995). Several PCR-based detection methods have been widely utilised (Szabo et al., 1994a; Szabo et al., 1994b; Takeshi et al., 1996; Branconnier et al., 2001).

The use of a cultural enrichment followed by a PCR procedure has been recommended (Hielm et al., 1996; Dahlenborg et al., 2001) because it provides higher number of target bacteria and reduces problems due to the presence of extracellular DNA, bacterial death, or to interference by food components. Quantitative detection of C. botulinum using a MPN series of dilutions, with cultural enrichment, followed by PCR tests has been used to quantitatively detect $C$. botulinum type $E$ in inoculated fish. It has also been used to investigate the presence of these bacteria in aquatic sediments and in fish 
(Aranda et al., 1997; Hielm et al., 1996; Hielm et al., 1998). In situ (without prior enrichment) detection of $C$. botulinum type $C_{1}$ neurotoxin by using a nested PCR assay was reported by Williamson et al. (1999). In the reverse transcription-PCR developed by McGrath et al. (2000), gene expression is detected rather than the gene itself. It may distinguish between viable and dead bacteria.

Compared to MBA, PCR has been found to be more sensitive, rapid, and does not require experimental animals (Fach et al., 1993; Szabo et al., 1993; Szabo et al., 1994b). A sensitivity of 10-12.5 fg of DNA, that is approximately equal to 3-5 cells in a reaction volume was reported by Fach et al. (1993) and Szabo et al. (1993). An amount of 0.3 ng of DNA was also detected by Craven et al. (2002).

The technique developed by Fach et al. (2002) based on identification of the most highly conserved region of botulinal neurotoxin genes can be automated and readily applied for simultaneous detection of $C$. botulinum types $A, B, E$, and F on a large scale. Multiplex-PCR developed by Lindström et al. (2001), which was then slightly modified by Nevas et al. (2005a) was used to detect $C$. botulinum types $A, B, E$, and $F$ in food, faecal materials, and honey.

The PCR-based assays have demonstrated their advantages for rapid and accurate identification of pathogenic bacteria. However, the limitations of these assays are that they are primarily qualitative techniques and are not appropriate for accurate quantification of a target sequence. Numbers of quantitative PCR approaches to the detection and quantification of target gene numbers have been developed, such as most probable number PCR (MPN-PCR) (Hielm et al., 1996), competitive PCR (Lee et al., 1996; Janse et al., 1998; McGrath et al., 2000), and PCR-ELISA (Gutierrez et al., 1997; Gonzalez et al., 1999). Most recently, the TaqMan real-time PCR assays have been developed based on sequence-specific hybridization probes; i.e., the 5'-3' exonuclease activity of Taq polymerase. These assays have been applied for quantification of various pathogenic bacteria such as Mycobacterium tuberculosis (Desjardin et al., 1998), Vibrio parahaemolyticus (Kaufman et al., 2004), Yersinia pestis (Higgins et al., 1998), and Salmonella (Nogva and Lillehaug, 1999; Mercanoglu and Griffiths, 2005). 


\subsection{Botulism in man}

Botulism was first recognised as "sausage poisoning" in the $18^{\text {th }}$ and $19^{\text {th }}$ centuries. The causative agent was first described by van Ermengem in 1897 from a large outbreak in Ellezelles, Belgium. Human botulism is mainly caused by $C$. botulinum strains that produce toxin types $A, B$, and E. Neurotoxigenic strains of C. butyricum (Aureli et al., 1986) and C. baratii (Hall et al., 1985; McCroskey et al., 1991), which produce types $E$ and $F$ toxin, respectively, have also been recently reported in human botulism. In humans there have been only two reported outbreaks of poisoning with type $C$, and one with type $D$ toxin (Lamanna, 1959). Type $C_{\alpha}$ reported by K.F. Meyer (cited by Prevot et al., 1955) as type $C$ botulism in the USA, type $\mathrm{C}_{\beta}$ in a foodborne outbreak in France (Prevot et al., 1955), and type D in an outbreak of botulism in humans in Chad (Demarchi et al., 1958) were reported. Humans are very sensitive to botulism. There is no person-to-person transmission.

There are now five clinical forms of human botulism (Cherington, 1998; 2004). Classic (also called food-borne) and wound botulism, which were the only two forms of botulism known until the last quarter of the $20^{\text {th }}$ century, were recognised in 1897 and 1943, respectively. The other forms have been described over the past decades, except for botulinal intestinal infections reported in 1928 by Meyer. Infant botulism, first described in 1976, is the most frequently reported form in the USA. The hidden form, described in 1977, is the adult variation of infant botulism. Inadvertent botulism, the most recent form to be described (in 1997), is an unintended consequence of treatment with injections of botulinum toxins for therapeutic or cosmetic use.

The neurological signs and symptoms are the same for all epidemiological categories and may include respiratory paralysis or neuronal failure (Dressler, 2002). However, the pathogenesis varies among the different forms. While classic or food-borne botulism is an intoxication that results from the ingestion of preformed toxin, infant, hidden, and wound botulism are infectious forms (Cherington, 1998; 2004). 


\subsubsection{Food-borne botulism}

Food-borne botulism occurs after the ingestion of foods containing preformed toxin. The contamination occurs in susceptible foods stored at ambient temperatures for prolonged periods. The sources of food-borne botulism are mainly fish, meat, dairy products, and vegetables. Home canned foods made from fish, vegetables, or potatoes were often implicated in food-borne botulism outbreaks (Hauschild, 1989; Dodds, 1993b). It has been shown that in home canned foods $C$. botulinum spores survive inadequate cooking and canning processes, germinate, reproduce, and produce toxin. Types A, B, and E are implicated in most human cases. Although the clinical presentations of these three types are similar, type $A$ cases may be more severe and longer lasting with a higher fatality rate than those caused by type B (Woodruff, 1992). Type $E$ was reported the prevalent type associated with botulism outbreaks in Alaska, Canada, Denmark, Norway, the former Soviet Union, Iran, and Japan (Hauschild, 1993). The number of reported cases associated with type $F$ toxin was low (Midura, 1972; Hauschild, 1993).

Mortality was reported to be high in the USA from 1899-1949 with the approximate case-fatality ratio at $60 \%(C D C, 1998)$ because treatment was unsatisfactory (Meyer, 1964). Due to improvements in supportive and respiratory intensive care and to the prompt administration of antitoxin, the case-fatality ratio has decreased over years for all toxin types. In the USA, it was $15.5 \%$ in the period from 1950 to 1996 (CDC, 1998).

\subsubsection{Infant botulism}

In reference to the present study, infant botulism is focused on and reviewed in more detail.

\subsubsection{Epidemiology}

Infant botulism is defined as: "a clinically compatible case that is laboratoryconfirmed, occurring in children under 1 year of age" (CDC, 1997). This form 
occurs when $C$. botulinum spores are ingested, germinate, colonise, and produce neurotoxin in the gastrointestinal tract. Infants are susceptible to gut colonisation due to immaturity of the host gut microflora.

Infant botulism was first recognised and described in the USA in 1976 (Midura and Arnon, 1976). Since the first case of infant botulism was reported in England in 1978 (Turner et al., 1978), 49 cases have been described in Europe (Aureli et al., 2002). To date, the CDC has documented more than 1,400 cases in all continents, except Africa. Approximately, $90 \%$ of the cases have been diagnosed in the USA (Shapiro et al., 1998). In Germany, as many as 100-200 cases of so called "sudden infant botulism" per year were estimated (Böhnel et al., 2001a).

Most infant botulism cases are due to $C$. botulinum types A and B. Proteolytic C. botulinum strains are more frequently related to infant botulism than nonproteolytic strains (Arnon, 1998). The first case of infant botulism caused by type $C$ was reported in Japan (Oguma et al., 1990). In addition to cases caused by $C$. botulinum, there have been cases due to Clostridium butyricum and Clostridium baratii producing types $\mathrm{E}$ and $\mathrm{F}$ toxin respectively (Hall et al., 1985; Aureli et al., 1986; Gimenez and Sugiyama, 1988). It was postulated by Sonnabend et al. (1985) that the strain producing type $G$ botulinum toxin was also associated with infant botulism.

While $99 \%$ of affected babies were less than one year old, $94 \%$ of cases occurred in infants less than six months old with a median of ten weeks (Brown, 1984; Spika et al., 1989). Two cases of infant botulism at six and eight days of life were reported by Thilo and Townsend (1993). Recently, a case of botulism in a 54-hour-old infant has been recognised the youngest case of infant botulism. It is the third reported case caused by $C$. botulinum type $\mathrm{F}$ (Keet et al., 2005). A slightly higher prevalence in male infants was reported.

In approximately $85 \%$ of infant botulism cases the source of spore ingestion is unknown and in up to $15 \%$ of cases honey is suspected to be the source of the ingestion (Spika et al., 1989; Arnon, 1998).

While the minimum infective dose of $C$. botulinum spores for infants is not known, it has been estimated to be as low as 10 to 100 spores (Arnon, 1998). A 
dose of 10 spores was found to be infective for experimental infant mice (Sugiyama and Mills, 1978).

\subsubsection{Clinical spectrum}

Infant botulism is difficult to recognise because of its insidious onset. The disease has a broad clinical spectrum ranging from a mild infection to fulminating, even fatal illness. The initial clinical sign is usually constipation. This symptom is followed by poor feeding, lethargy, weak cry, poor suck, and generalised decrease in muscle tone characterised by loss of head control. The baby often appears "floppy" (Arnon et al., 1977; Arnon, 1998). Respiratory difficulties occur as a late sign of the disease and quickly lead to respiratory arrest (Schmidt and Schmidt, 1992). A mortality rate of 5\% has been reported (Kothare and Kassner, 1995). The illness may last from a few days to weeks or months, and recovery may also take weeks or months.

\subsubsection{Diagnosis}

Electromyogram (EMG) studies are usually the quickest way to diagnose botulism. EMG also may help to distinguish botulism from myasthenia gravis and Guillain-Barré syndrome, which are still frequently misdiagnosed as botulism (Arnon, 1998).

A definitive diagnosis includes the detection of botulinum toxin and the isolation of $C$. botulinum from stool specimens. A serum sample is necessary for a toxin assay. Additionally, other potential samples, such as honey, corn, infant formula foods, dust, and other materials in the surrounding environment of affected babies, should be collected for diagnosis (Arnon, 1998; CDC, 1998; Cox and Hinkle, 2002; Nevas et al., 2005b).

Clinical diagnosis is based on a careful examination of neurological symptoms. In addition to the neurological symptoms, absence of fever despite alertness of senses is considered distinctive for infant botulism. 
It has been noted that infant botulism goes undetected in many areas (Fox et al., 2005). The differential diagnosis of infant botulism includes other neuromuscular disorders associated with hypotonia. These include myopathies, Guillain-Barré syndrome, familial infantile myasthenia gravis, spinal muscular atrophy, and poliomyelitis (Cherington, 1998; Cox and Hinkle, 2002). Böhnel et al. (2001a) proposed to use "sudden infant botulism" for cases of unexpected infant death with post-mortem findings of $C$. botulinum bacteria/toxins to differentiate from clinical floppy infant syndrome.

\subsubsection{Treatment}

The treatment for infant botulism has been based on supportive treatment including respiratory and nutritional care. Prompt clinical diagnosis and treatment with Botulism Immune Globulin (BIG) may reduce the recovery time. BIG is obtained from pooled plasma of adults immunised with pentavalent botulinum toxoid and selected for high titres of neutralizing antibodies against types A and B toxin (Frankovich and Arnon, 1991). Since BIG was approved by the Food and Drug Administration in 2003 for use in infant botulism in the USA, therapy with BIG significantly reduces hospital stay and hospital costs and diminishes the potential complications of the disorder (Arnon, 1998; Thompson et al., 2005). It is recommended in the USA that BIG treatment should be requested without waiting for laboratory confirmation. Antibiotics are not used in uncomplicated infant botulism cases because the toxin may be released into the intestine following death and lysis of vegetative cells.

\subsubsection{Prevention}

Currently, the only known way to prevent the acquisition of infant botulism is to avoid feeding honey to infants less than one year old. This recommendation has been endorsed by paediatric and public health agencies. Moreover, breastfeeding has been recommended to moderate the rapidity of onset and the severity of the disease (Arnon et al., 1982; Spika et al., 1989). 
Botulism presents a public health emergency. It is obligated to report to departments of health services in case of a botulism case with 1) a clinical epidemiological confirmation; 2) a probable clinically confirmed case of botulism after laboratory detection confirmation; 3) an asymptomatic infection which is laboratory detected; 4) or an infection with only laboratory detection confirmation (Robert Koch Institute, 2000). If a case is clinically or laboratory confirmed or if a bio-terrorism event is suspected, all concerned agencies such as state and local infectious disease and epidemiology departments, must be notified.

\subsubsection{Link to sudden infant death syndrome (SIDS)}

Sudden Infant Death Syndrome (SIDS) is the "sudden death of an infant under one year of age which remains unexplained after a thorough case investigation, including performance of a complete autopsy, examination of the death scene, and review of the clinical history" (Willinger et al., 1991).

A link between infant botulism and SIDS was noted because of a similar sudden respiratory arrest found in cases of infant botulism and SIDS. Sudden unexpected death in cases of infant botulism led to the hypothesis that infant botulism might be a cause of SIDS (Arnon et al., 1981). The age distribution of SIDS is identical to that of infant botulism. C. botulinum and toxin were found in 10 of 212 tests of necropsy specimens (Arnon et al., 1978; Arnon et al., 1981). However, in a 10-year study conducted in Australia by Byard and his coworkers (1992), none of the small and large intestine specimens from 248 SIDS cases was positive for $C$. botulinum by culture. Similar conclusions were made by Urquhart and Grist (1976) and Berry et al. (1987). While infant botulism was not associated with SIDS in Southern Australia, C. botulinum and the toxin were found in cases in North America and Europe (Hauschild et al., 1983; Hauschild and Gauvreau, 1985; Midura, 1996; Böhnel et al., 2001a). 


\subsubsection{Risk factors for infant botulism}

Through laboratory and epidemiological evidence, it is conclusive that consumption of honey is associated with infant botulism. Therefore, consumption of honey should be considered as the most important risk factor associated with infant botulism.

In a two-year prospective case-control study conducted by Spika et al. (1989), risk factors for infant botulism were defined. In addition to honey consumption, lack of breast-feeding and decreased frequency of bowel movement, namely less than one per day for at least two months, were also associated with the disease in infants less than two months of age. Another significant risk factor is living in a rural area or on a farm (Hoffman et al., 1988).

\subsubsection{Wound botulism}

Until recently, wound botulism has been considered a rare form of botulism. From 1943 to 1990, there were 47 cases of wound botulism reported (Weber, 1993). Wounds contaminated with C. botulinum spores result in wound botulism. The rarity of this form is due to the failure of the spores to germinate readily in tissue. Since 1991, there has been a dramatic increase in the numbers of wound botulism reported in drug addicts injecting black tar heroin subcutaneously (Maselli, 1997; Passaro et al., 1998; Werne et al., 2000; CDC, 2003). The fatality rate for wound botulism is approximately $15 \%$ (Hatheway, 1995).

\subsubsection{Hidden botulism}

This form refers to adult patients who accommodate toxin-producing clostridia bacteria in their intestinal tracts. This occurs while there is no known contaminated food, no wound, and no history of drug abuse. Toxin production is similar to that of infant botulism. The hidden botulism patients often have a history of gastrointestinal tract abnormalities, abdominal surgery, or recent antibiotic treatment (Dowell, 1977; Chia, 1986; Griffin, 1997). 
2.3.5 Inadvertent botulism

Inadvertent botulism is the most recently recognised form. This form of botulism occurs in patients treated dystonic and other movement disorders with botulinum toxin (Cherington, 1998; Munchau and Bhatia, 2000). Botulinum neurotoxin types $A, B, C$, and $F$ are used now in these treatments (Eleopra et al., 2004). Clinical weakness and electrophysiologic abnormalities were observed in inadvertent botulism cases (Bakheit et al., 1997). 


\section{OBJECTIVES}

Objectives of this study were:

1. Development of a procedure to produce spore suspensions of different strains of $C$. botulinum A, B, C, D, E, and F by applying different media.

2. Development of a MPN-PCR method to enumerate spores of these strains in honey samples, targeting the neurotoxin encoding genes.

3. Detection for the presence of viable $C$. botulinum spores in honey samples and infant foods purchased from retail stores and supermarkets in Ho Chi Minh City, Vietnam. In addition, some honey and infant food samples that were purchased from retail supermarkets in Germany were also examined. The purpose of this survey was to determine if honey and infant foods in these market areas would present a potential threat to infants in Vietnam and Germany. 


\section{MATERIALS AND METHODS}

\subsection{Bacterial strains and culture conditions}

Bacterial strains used were C. botulinum types A, C, D, E and proteolytic types $B$ and $F$. Strains were obtained from the culture collection at the Institute of Agronomy and Animal Production in the Tropics and Subtropics, Georg-AugustUniversity Göttingen. Table 2 shows all strains with their origins. 
Table 2: Origin of the $C$. botulinum strains

\begin{tabular}{|c|c|c|c|}
\hline Institute's number & Type & $\begin{array}{l}\text { Original } \\
\text { number }\end{array}$ & Source \\
\hline 2298 & $A$ & $62 \mathrm{~A}$ & $\begin{array}{l}\text { Prof. Kozaki, Osaka Prefecture } \\
\text { University, Japan }\end{array}$ \\
\hline 2299 & $B$ & Okra & $\begin{array}{l}\text { Prof. Kozaki, Osaka Prefecture } \\
\text { University, Japan }\end{array}$ \\
\hline 2300 & C & $003-9$ & $\begin{array}{l}\text { Prof. Kozaki, Osaka Prefecture } \\
\text { University, Japan }\end{array}$ \\
\hline 2145 & $\mathrm{C}$ & REB 1455 & $\begin{array}{l}\text { National Reference Centre for } \\
\text { Clostridia, Erfurt, Germany }\end{array}$ \\
\hline 2294 & C & 5295 & $\begin{array}{l}\text { New Zealand Reference Culture } \\
\text { Collection, New Zealand }\end{array}$ \\
\hline 2256 & $\mathrm{C}_{\beta}$ & $\mathrm{AO} 28$ & IDLO, Lelystad, Netherlands \\
\hline 2257 & $\mathrm{Ca}$ & $468 \mathrm{C}$ & IDLO, Lelystad, Netherlands \\
\hline 1969 & C & NC 03180 & NCTC* \\
\hline 2279 & $\mathrm{Ca}$ & CCUG7970 & $\begin{array}{l}\text { Culture Collection, University of } \\
\text { Göteborg, Schweden }\end{array}$ \\
\hline 2301 & $\mathrm{D}$ & CB-16 & $\begin{array}{l}\text { Prof. Kozaki, Osaka Prefecture } \\
\text { University, Japan }\end{array}$ \\
\hline 2302 & $E$ & 35396 & $\begin{array}{l}\text { Prof. Kozaki, Osaka Prefecture } \\
\text { University, Japan }\end{array}$ \\
\hline 2271 & $E$ & CECT 4611 & $\begin{array}{l}\text { Spanish Collection of Culture Type, } \\
\text { Valencia, Spain }\end{array}$ \\
\hline 2625 & $E$ & CB-S 21E & Miia Lindström, Helsinki \\
\hline 2303 & $\mathrm{~F}$ & Langeland & $\begin{array}{l}\text { Prof. Kozaki, Osaka Prefecture } \\
\text { University, Japan }\end{array}$ \\
\hline
\end{tabular}

(*): NCTC, National Collection of Type Cultures, United Kingdom

The stock cultures of each strain were maintained frozen at $-80^{\circ} \mathrm{C}$ in $2 \mathrm{~mL}$ of RCM (Reinforced Clostridial Medium) cultures with $10 \%$ glycerine added. These 
were inoculated into $5 \mathrm{~mL}$ of $\mathrm{RCM}$ and incubated at $37^{\circ} \mathrm{C}$ under anaerobic conditions. The incubation conditions were a combination of $90 \% \mathrm{~N}_{2}, 5 \% \mathrm{CO}_{2}$, and $5 \%$ of $\mathrm{H}_{2}$ (ANOXOMAT® SYSTEM, MART, Lichtenvoorde, the Netherlands). These were applied for all stages of the study. After two days of incubation, growth and gas production of the cultures were controlled. These cultures were then inoculated into $5 \mathrm{~mL} R C M$ tubes and checked for any contamination by further BA (Blood Agar with RCM basis) culture with two days of incubation. The pure cultures that did not have any contamination, i.e. having given apparently only one kind of colony on BA, were further inoculated into 20 $\mathrm{mL}$ of RCM tubes and incubated under anaerobic conditions for 2-4 $\mathrm{d}$. Then the growing cultures were frozen in $2 \mathrm{~mL}$ tubes at $-80^{\circ} \mathrm{C}$. These cultures were used for subsequent studies.

\subsection{Media}

For spore production, various media were applied (Table 3), whereas for spore enumeration, Fastidious Anaerobe Broth (FAB) and Cooked Meat Medium (CMM - DIFCO, Detroit, USA) were used. (Detailed components see Appendix). 
Table 3: Media applied for spore production of C. botulinum

\begin{tabular}{|c|c|c|}
\hline Procedure & Media & Authors/Manufacturers \\
\hline \multirow{18}{*}{$\begin{array}{l}\text { Spore } \\
\text { production }\end{array}$} & Blood Agar (BA) & see Appendix \\
\hline & Egg Yolk Agar (EYA) & see Appendix \\
\hline & Fastidious Anaerobe Agar with & Saeed, 2005 \\
\hline & Blood (FAAB) & \\
\hline & Fastidious Anaerobe Agar with & Saeed, 2005 \\
\hline & Egg Yolk (FAAE) & \\
\hline & Duncan-Strong Medium (DSM) & Duncan and Strong, 1968 \\
\hline & Modified Anellis Broth (MAB) & Gaze and Brown, 1988 \\
\hline & $\begin{array}{l}\text { Reinforced Clostridial Medium } \\
\text { (RCM) }\end{array}$ & see Appendix \\
\hline & RCM-hay * & see Appendix \\
\hline & Segner Medium (SeM) & Segner et al., 1971 \\
\hline & Sporulation Medium (SM) & Medium 531 - German \\
\hline & & Collection of \\
\hline & & Microorganisms and Cell \\
\hline & & Cultures, Braunschweig, \\
\hline & & Germany \\
\hline & SM-hay & see Appendix \\
\hline & Trypticase medium (TM) & Durban et al., 1970 \\
\hline Spore & Fastidious Anaerobe Broth (FAB) & see Appendix \\
\hline enumeration & Cooked Meat Medium (CMM) & DIFCO, Detroit \\
\hline
\end{tabular}

*, addition of hay to medium (Mitscherlich - personal communication to Böhnel, 1985).

\subsection{Honey and infant food samples}

Honey and infant food samples were purchased from retail stores and supermarkets in Ho Chi Minh City, Vietnam. The infant food samples had instant cereal as the basic component and another component like pork, chicken, shrimp, or fish meat, milk, fruit, vegetables, rice, or soya bean. These samples were divided into five groups based on the other components. Some 
other samples were purchased from retail supermarkets in Germany. The numbers and types of samples tested are listed in Tables 4 and 5.

Table 4: Types of samples collected from Ho Chi Minh City, Vietnam

\begin{tabular}{llc}
\hline \multicolumn{1}{c}{ Types of samples } & Number of samples \\
\hline Honey & & 99 \\
\hline \multirow{3}{*}{ Infant Foods } & Pork/Chicken & 50 \\
& Milk & 35 \\
& Fruit/Vegetables & 35 \\
& Shrimp/Fish & 30 \\
& Rice/Soya bean & 29 \\
\hline Total & & $\mathbf{2 7 8}$
\end{tabular}

Table 5: Types of samples purchased in Germany

\begin{tabular}{lc}
\hline Types of samples & Number of samples \\
\hline Honey & 13 \\
Infant cereal formula & 9 \\
Infant milk powder & 9 \\
Potato purée & 8 \\
Vegetable formula & 7 \\
\hline Total & 46 \\
\hline
\end{tabular}

\subsection{Spore production}

Spores of the $C$. botulinum A to $F$ strains were produced separately by growing in various media (Table 6). $0.1 \mathrm{~mL}$ of bacterial cultures of $C$. botulinum $A$ to $F$ strains were inoculated into $5 \mathrm{~mL}$ of $\mathrm{FAB}$, incubated anaerobically at $30-37^{\circ} \mathrm{C}$ for $2 \mathrm{~d}$. Two millilitres of this culture were then inoculated into $20 \mathrm{~mL} F A B$ and incubated under the same condition for 2-4 d. The whole $20 \mathrm{~mL}$ of the FAB culture were then transferred to media for spore production. The sporulation level was checked daily by microscopic examination after Gram or spore staining. If spores were produced on FAAE or BA, anaerobic incubation for $4 \mathrm{~d}$ at $30-37{ }^{\circ} \mathrm{C}$ was carried out. Spores on agar plates were washed off with cold sterile PBS. If there were more than approximately $60 \%$ of spores compared 
with rod forms observed, spores were collected by centrifugation at 5,000 $\times g$ for $15 \mathrm{~min}$ and resuspended in spore salt solution (SSS, see Appendix - Böhnel, personal communication). This was stored at $4{ }^{\circ} \mathrm{C}$ for further $4-7 \mathrm{~d}$ for further transformation into the spore form from the vegetative cells. Finally, spores were harvested by centrifugation at 5,000 $\mathrm{g}$ for $15 \mathrm{~min}$ and washed with cold sterile water five times. Sonication in an ultrasonic bath (SONOREX DK 514 BP, BANDELIN, Berlin, Germany) with washing was carried out five times to avoid clumping of spores (Peck et al., 1992). The washed spores were then resuspended in Phosphate Buffered Saline solution (PBS) pH 7.2, and stored at $4{ }^{\circ} \mathrm{C}$. The degree of sporulation was estimated by examining ten microscopic fields (1,000 x magnification). It was classified as poor (lower than $30 \%)$, fair (30-70\%), and good (from $70-100 \%$ ). 


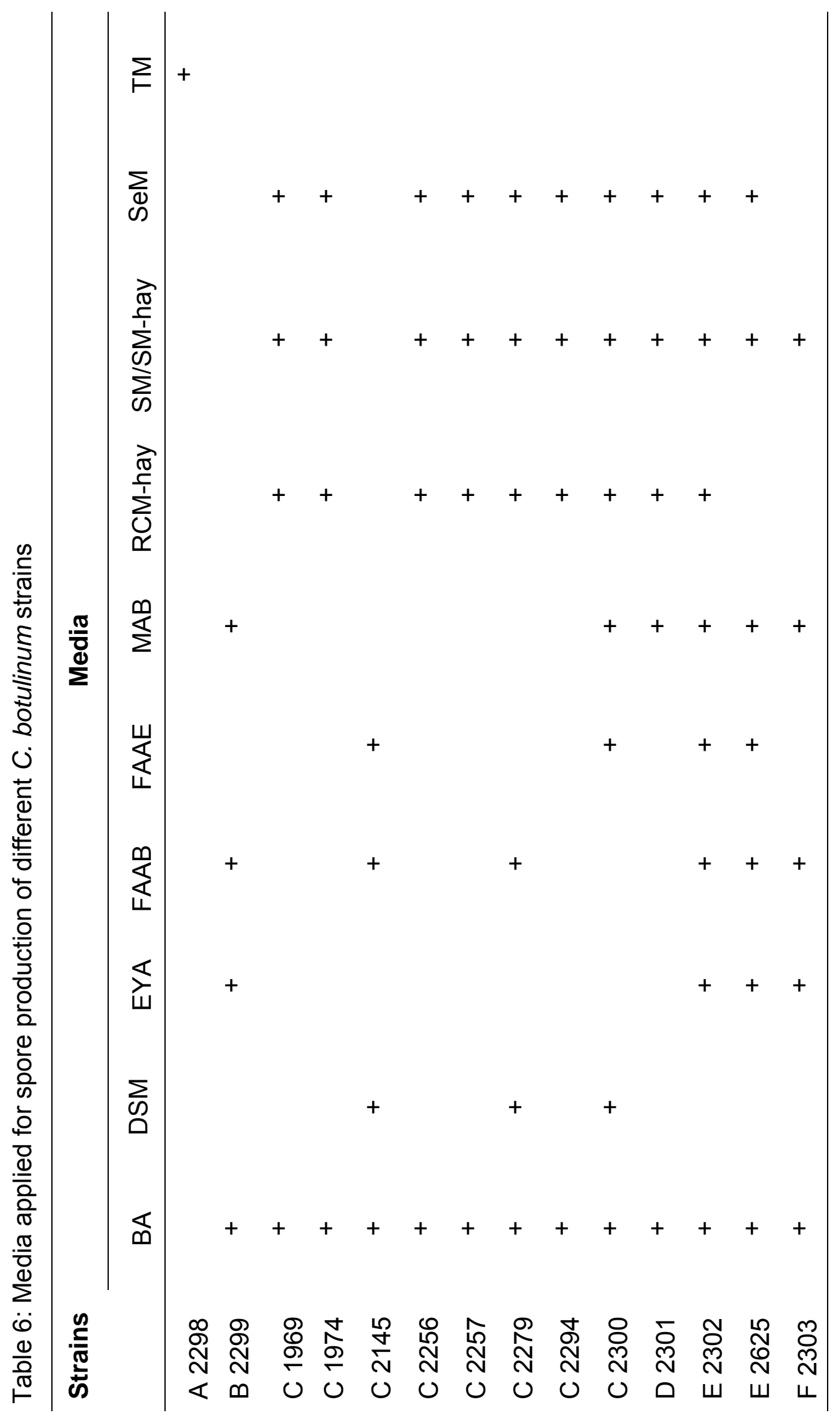




\subsection{Enumeration procedure}

The enumeration of $C$. botulinum spores in spore suspensions and in spiked honey was determined using the five-tube-MPN method (Most Probable Number) (Peeler et al., 1992; Blodgett, 2001) in CMM and FAB. This was confirmed by mouse bioassay (MBA) and PCR.

Series of 5 tubes containing $4.5 \mathrm{~mL}$ of $\mathrm{CMM}$ and $\mathrm{FAB}$ were inoculated with $0.5 \mathrm{~mL}$ of spore suspension or $0.5 \mathrm{~g}$ honey. This was considered as the $10^{-1}$ dilution. For further dilutions, spore suspension and honey samples were 10-fold serially diluted in sterile water. From each dilution, $0.5 \mathrm{~mL}$ was transferred to 5 tubes containing $4.5 \mathrm{~mL}$ of enrichment media. For spore suspension, duplicate test samples were tested in $\mathrm{FAB}$; while for honey samples $\mathrm{CMM}$ and $\mathrm{FAB}$ were used in parallel to determine which medium was better for recovery of $C$. botulinum spores. All tubes were heated at $60{ }^{\circ} \mathrm{C}$ for $30 \mathrm{~min}$, and then cooled immediately with cold water. The number of spores in suspension of each strain was obtained after an anaerobic incubation for $4 \mathrm{~d}$ at $35-37^{\circ} \mathrm{C}$. Tubes showing bacterial growth were checked with PCR and MBA. The number of $C$. botulinum spores was obtained by converting the number of positive tubes to a MPN from the reference table (Peeler, 1992).

\subsection{Procedures for detection of $C$. botulinum spores in honey and infant foods}

After enrichment in the liquid media, PCR was carried out targeting the botulinal neurotoxin encoding genes. The confirmation of PCR positive samples was based on the restriction enzyme analysis of PCR products and DNA sequencing. A parallel confirmation by mouse bioassay was carried out.

\subsection{Preparation of honey and infant food samples}

A 20-25 g portion of honey was weighed under a laminar hood and added to a 500 $\mathrm{mL}$ screw-capped flask (ROTH, Karlsruhe, Germany) containing $200 \mathrm{~mL}$ of CMM 
or FAB that had been warmed up to about $40-45^{\circ} \mathrm{C}$, and mixed well. For infant food samples, FAB was used as enrichment medium. From this diluent, $0.5 \mathrm{~mL}$ were pipetted to each of $4.5 \mathrm{~mL}$ broth tubes of FBA, RCM, and CMM, and mixed well. All of the tubes and flasks were then heated in a water bath at $60{ }^{\circ} \mathrm{C}$ for 30 min and incubated at $35-37^{\circ} \mathrm{C}$ for 3-7 $\mathrm{d}$. The proteolytic activity was examined by observation of the ability to digest cooked meat pellets in CMM.

\subsection{Preparation of spiked honey samples for enumeration of $C$. botulinum spores}

Honey was purchased from supermarkets and sterilised by autoclaving it at $115^{\circ} \mathrm{C}$ for $30 \mathrm{~min}$. After sterilisation, the honey was streaked onto blood agar plates and also put into FAB tubes. This was incubated aerobically and anaerobically for 3-7 d for examination of sterility. Under a laminar flow hood, $99 \mathrm{~g}$ of honey were put into $100 \mathrm{~mL}$ screw-capped bottles (ROTH, Karlsruhe, Germany). The honey bottles were heated at $50{ }^{\circ} \mathrm{C}$ for $1 \mathrm{~h}$. Aliquots of $1 \mathrm{~mL}$ of individual spore suspensions of each $C$. botulinum type A, B, C, D, E, or F were added to these bottles. To evenly distribute the inoculated spores, the honey bottles were placed on a magnetic stirrer at $50{ }^{\circ} \mathrm{C}$ for $1 \mathrm{~h}$.

The amount of spores of each strain of $C$. botulinum artificially inoculated to each honey sample is shown in Table 7. In addition, other bottles were inoculated with 1 $\mathrm{mL}$ of a mixture of all strains containing equal numbers of spores of each strain. Triplicate samples of inoculated honey were prepared. 
Table 7: Numbers of C. botulinum spores inoculated in honey (spores $\mathrm{g}^{-1}$ )

\begin{tabular}{lccl}
\hline Strain & Number of & \multicolumn{2}{c}{$95 \%$ confidence intervals } \\
\cline { 3 - 4 } & spores & Low & High \\
\hline A 2298 & $7 \times 10^{4}$ & $2 \times 10^{4}$ & $2 \times 10^{5}$ \\
B 2299 & $1 \times 10^{4}$ & $3 \times 10^{3}$ & $3 \times 10^{4}$ \\
C 2145 & $1 \times 10^{4}$ & $3 \times 10^{3}$ & $3 \times 10^{4}$ \\
D 2301 & $7 \times 10^{4}$ & $2 \times 10^{4}$ & $2 \times 10^{5}$ \\
E 2625 & $2.6 \times 10^{4}$ & $7 \times 10^{3}$ & $8 \times 10^{4}$ \\
F 2303 & $1.6 \times 10^{4}$ & $5 \times 10^{3}$ & $5 \times 10^{4}$ \\
Mixed (each type) & $1 \times 10^{3}$ & & \\
\hline
\end{tabular}

\subsection{Preparation of spiked infant food samples for detection of $C$. botulinum spores}

Infant foods were first checked for the presence of $C$. botulinum and its toxins by MBA and PCR after enrichment in FAB under anaerobic conditions at $35-37{ }^{\circ} \mathrm{C}$ for $7 \mathrm{~d}$. The negative samples in both procedures were used for the spiking.

Under a laminar flow hood, an amount of $19 \mathrm{~g}$ of infant food samples was weighed and inoculated with one millilitre of spore suspension containing equal numbers of spores of $C$. botulinum types $A, B, C, D, E$, and $F$. The same procedure was conducted as that for spiked honey samples. The final concentrations of $C$. botulinum were $0.1,1$, and 10 spores $\mathrm{g}^{-1}$ of honey or infant food sample. The spiked samples were checked for the presence of $C$. botulinum spores in parallel with purchased honey and infant foods to test the sensitivity of the applied methods.

\subsection{DNA isolation}

For preparation of DNA templates NucleoSpin Tissue kits (MACHEREY-NAGEL, Düren, Germany) were used according to the instructions of the manufacturer. One millilitre of bacterial culture was centrifuged for $5 \mathrm{~min}$ at $8,000 \times \mathrm{g}$ and the supernatant was discarded. The pellet was lysed by $180 \mu \mathrm{L}$ of T1 buffer and $25 \mu \mathrm{L}$ 
of proteinase $\mathrm{K}$ solution at $56^{\circ} \mathrm{C}$ for $3 \mathrm{~h}$, and then by $200 \mu \mathrm{L}$ of $\mathrm{B} 3$ buffer at $70^{\circ} \mathrm{C}$ for 10 min. After adjusting the DNA binding conditions with $210 \mu \mathrm{L}$ of $96 \%$ ethanol, the sample was applied to a column and centrifuged at 11,000 $\mathrm{xg}$ for $1 \mathrm{~min}$. This was followed by a further two step washing procedure. The first was in $500 \mu \mathrm{L}$ of BW in a centrifuge tube $(11,000 \times \mathrm{g}, 1 \mathrm{~min})$, and the second was in $600 \mu \mathrm{L}$ of B5 buffer and centrifuged again as before. After a further centrifugation at 11,000 x g for $1 \mathrm{~min}$ to remove any residual ethanol buffer B5 from the sample, the DNA products were eluted with $100 \mu \mathrm{L}$ of BE. These DNA products were used as DNA templates for the PCR procedure.

\subsection{PCR procedure}

The multiplex PCR assay (Lindström et al., 2001) was applied to detect $C$. botulinum type $A, B, E$, and $F$ toxin genes. For detection of $C$. botulinum type $D$ toxin genes, the PCR assay developed by Takeshi et al. (1996) was used. A recently developed method was applied to detect $C$. botulinum type $C$ toxin genes (Gessler and Böhnel, 2006). Primers used in PCR detection are shown in Table 8.

\subsection{Mouse bioassay}

White mice (NMRI mice, HARLAN WINKELMANN, Borchen, Germany) with 18-25 $g$ body weight were used for testing biological activity of the culture supernatants. After incubation, cultures were centrifuged at 4,000 $\mathrm{x}$ for 20-30 min. The supernatants were diluted 1:10 in gelatine-phosphate buffer $\mathrm{pH} 6.2$ (detailed components see Appendix), and $0.5 \mathrm{~mL}$ of each dilution was injected intraperitoneally (i.p.) (Smith and Sugiyama, 1988; CDC, 1998). The injected mice were observed for $4 \mathrm{~d}$ for signs of botulism such as ruffled fur, wasp-like narrowed waist, laboured respiration, paralysis, or death. Trypsin-treated materials and untreated duplicates were conducted in parallel. For trypsinisation, trypsin solution (20 mg trypsin [SIGMA-ALDRICH, Deisenhofen, Germany] in $10 \mathrm{~mL}$ sterile demineralised water stored at $-20^{\circ} \mathrm{C}$ ) was added to the culture supernatant as $1 \%$ $(\mathrm{v} / \mathrm{v})$ followed by incubation at $37^{\circ} \mathrm{C}$ for $30 \mathrm{~min}$. The toxicity is given in MLD mL 
corresponding to the reciprocal value of the highest dilution at which both mice showed typical signs and died.

Table 8: Primers for PCR detection of $C$. botulinum types $A$ to $F$

\begin{tabular}{cllcc}
\hline $\begin{array}{c}\text { Toxin } \\
\text { type* }\end{array}$ & name & Primer sequence (5'-3') & $\begin{array}{c}\text { PCR } \\
\text { product } \\
\text { size } \\
\text { (bp) }\end{array}$ & $\begin{array}{c}\text { Location on } \\
\text { gene } \\
\text { (coding } \\
\text { region) }\end{array}$ \\
\hline$A_{f}$ & CBMLA1 & AGC TAC GGA GGC AGC TAT GTT & 782 & $1788-1808$ \\
$A_{r}$ & CBMLA2 & CGT ATT TGG AAA GCT GAA AAG G & & $2569-2548$ \\
$B_{f}$ & CBMLB2 & CAG GAG AAG TGG AGC GAA AA & 205 & $434-453$ \\
$B_{r}$ & CBMLB2 & CBMLB2 CTT GCG CCT TTG TTT TCT TG & & $638-619$ \\
C $_{f}$ & CP3-01 & CTG AAA AAG CCT TTC GCA TT & 452 & $98-117$ \\
C $_{r}$ & CP3-02 & TTG TGC CGC AAA AGTATT GT & & $530-549$ \\
$D_{f}$ & DS-11 & GTG ATC CTG TTA ATG ACA ATG & 497 & $32-52$ \\
$D_{r}$ & DS-22 & TCC TTG CAA TGT AAG GGA TGC & & $508-528$ \\
$E_{f}$ & CBMLE1 & CCA AGA TTT TCA TCC GCC TA & 389 & $156-175$ \\
$E_{r}$ & CBMLE2 & GCT ATT GAT CCA AAA CGG TGA & & $544-525$ \\
$F_{f}$ & CBMLF1 & CGG CTT CAT TAG AGA ACG GA & 543 & $185-194$ \\
$F_{r}$ & CBMLF2 & TAA CTC CCC TAG CCC CGT AT & & $727-708$ \\
\hline * & & & \\
\hline
\end{tabular}

* Subscript f, forward primer; subscript $r$, reverse primer.

The PCR reaction mixture consists of $25 \mu \mathrm{L}$ of Bioron mastermix (BIORON, Ludwigshafen, Germany), $1 \mu \mathrm{L}$ of each primer, $3 \mu \mathrm{L}$ of DNA template, and sterile deionised water to a final volume of $50 \mu \mathrm{L}$. For multiplex PCR, $1.65 \mu \mathrm{L}$ of $\mathrm{MgCl}_{2}$ $(0.33 \mathrm{mM})$ are added into the PCR reaction mixture. The primer sets used in the present study were adopted from the above-mentioned assays. The Bioron mastermix contains in $1.25 \mu \mathrm{L}$ : Taq DNA polymerase $\left(0.1\right.$ units $\left.\mu \mathrm{L}^{-1}\right)$, antibodies to 
Taq DNA polymerase, $130 \mathrm{mM}$ TrisHCl (pH 8.8 at $\left.25^{\circ} \mathrm{C}\right), 32 \mathrm{mM}\left(\mathrm{NH}_{4}\right)_{2} \mathrm{SO}_{4}$, $0.02 \%$ Tween-20, $3 \mathrm{mM} \mathrm{MgCl} 2$, dNTPs $(0.4 \mathrm{mM}$ of each of dATP, dCTP, dGTP, and dTTP).

A programmable thermocycler (TGRADIENT, BIOMETRA, Göttingen, Germany) was used for the amplification. Each multiplex PCR consists of an initial denaturation at $94{ }^{\circ} \mathrm{C}$ for $10 \mathrm{~min} ; 27$ cycles of denaturation $\left(95^{\circ} \mathrm{C}\right.$ for $30 \mathrm{~s}$ ), annealing $\left(60{ }^{\circ} \mathrm{C}\right.$ for $25 \mathrm{~s}$ ), and extension $\left(72{ }^{\circ} \mathrm{C}\right.$ for $1 \min 25 \mathrm{~s}$ ); and a final extension at $72^{\circ} \mathrm{C}$ for $3 \mathrm{~min}$. For types $\mathrm{C}$ or D PCR, after the same initial denaturation at $94{ }^{\circ} \mathrm{C}$ for $10 \mathrm{~min} ; 30$ cycles of denaturation $\left(94^{\circ} \mathrm{C}\right.$ for $\left.1 \mathrm{~min}\right)$, annealing ( $55^{\circ} \mathrm{C}$ for $1 \mathrm{~min}$ ), and extension ( $72{ }^{\circ} \mathrm{C}$ for $1 \mathrm{~min}$ ); and a final extension at $72{ }^{\circ} \mathrm{C}$ for $10 \mathrm{~min}$ followed. The amplified PCR products were visualised in $2 \%$ agarose gels (MERCK, Darmstadt, Germany) stained with ethidium bromide. Positive and negative controls were run with each PCR. The sizes of the amplification products were measured by using standard DNA fragments (DNA molecular weight marker VI, FINNZYMES, Espoo, Finland). The visualisation and photographs of the amplification products were carried out with a UV transilluminator (MWG-BIOTECH, Ebersberg, Germany).

\subsection{Restriction enzyme analysis of PCR products}

The PCR products were first concentrated by ethanol precipitation. A volume of $0.30 \mu \mathrm{L}$ of PCR products were mixed well with $3 \mu \mathrm{L} 3 \mathrm{M} \mathrm{NaOAc}(\mathrm{pH} 5.2)$ and $70 \mu \mathrm{L}$ ice cold ethanol $96 \%$, which was chilled to $-20^{\circ} \mathrm{C}$ just prior to use. The mixture was left overnight at $-20^{\circ} \mathrm{C}$ and then centrifuged at $10,000 \times g$. The supernatant was discarded and the precipitate was dried inside a biological hood for 30-40 min to remove the residual ethanol. The pellet was then resuspended with $10 \mu \mathrm{L}$ of EB buffer (10 mM Tris $\cdot \mathrm{Cl}, \mathrm{pH}$ 8.5). PCR products of types $\mathrm{A}, \mathrm{B}, \mathrm{E}$, and $\mathrm{F}$ were treated by Dral (QBIOGENE, Heidelberg, Germany), while PCR products of types $C$ and $D$ were digested by Mboll (QBIOGENE, Heidelberg, Germany) (Table 9). 
Table 9: Restriction enzymes used in the restriction enzyme analyses

\begin{tabular}{clccc}
\hline Type & Reference strain* & Enzyme & Fragments & Fragment size \\
\hline A & X52066 & Dral & 2 & $136 ; 646$ \\
B & M81186 & Dral & 3 & $68 ; 153 ; 472$ \\
E & X62089 & Dral & 2 & $97 ; 293$ \\
F & L35496 (proteolytic) & Dral & 2 & $80 ; 463$ \\
F & M92906 (non-proteolytic) & Dral & 2 & $80 ; 463$ \\
C & X53751 & Mboll & 2 & $226 ; 246$ \\
D & S49407 & Mboll & 2 & $145 ; 373$ \\
\hline
\end{tabular}

${ }^{*}$ GenBank entries offered by the NCBI

Each restriction enzyme reaction included $5 \mu \mathrm{L}$ of ethanol-concentrated or purified PCR products, $0.01 \mu \mathrm{L}$ BSA (Bovine Serum Albumin), $0.09 \mu \mathrm{L}$ buffer provided by the producer, $0.9 \mu \mathrm{L}$ distilled water, and $0.2 \mu \mathrm{L}$ enzyme Mboll (or $0.1 \mu \mathrm{L}$ of enzyme Dral). The restriction reaction occurred at $37^{\circ} \mathrm{C}$ for $1 \mathrm{~h}$ in a water bath and was then inactivated by heating for $10 \mathrm{~min}$ at $65^{\circ} \mathrm{C}$ or $85^{\circ} \mathrm{C}$, for Mboll or Dral respectively. The digested products were visualised and recorded using the same procedure as that used for the PCR procedure.

\subsection{Purification of PCR fragments for sequencing}

PCR fragments from PCR-positive samples were purified for sequencing using Montage PCR filter units (MILLIPORE, Schwalbach, Germany) following the protocol of the supplier. One hundred $\mu \mathrm{L}$ of PCR fragments and $300 \mu \mathrm{L}$ distilled water or buffer EB (10 mM Tris· $\mathrm{Cl}, \mathrm{pH}$ 8.5) were pipetted into a spin column (reservoir) that was put into a provided $1.5 \mathrm{~mL}$ reaction tube and spun at $1,000 \mathrm{xg}$ for $15 \mathrm{~min}$. The filtrate was saved until the sample was analysed. The spin column was put into another clean $1.5 \mathrm{~mL}$ reaction tube and $20 \mu \mathrm{L}$ distilled water or buffer EB were pipetted carefully into the end of the reservoir without touching the 
membrane surface. The reservoir was inverted into a clean eppendorf and centrifuged at $1,000 \times \mathrm{g}$ for $2 \mathrm{~min}$. The purified PCR fragments were stored at -20 ${ }^{\circ} \mathrm{C}$ until sequencing.

\subsection{Sequencing analysis}

The DNA sequencing analysis was carried out at the Institute of Veterinary Medicine, Faculty of Agricultural Sciences, Georg-August University Göttingen, using an ABI PRISM 3100 Analyser (APPLIED BIOSYSTEMS, Foster City, USA). The primers used were similar to that used in the PCR procedures to obtain sequences of both ends from both DNA strands to obtain double-stranded sequences. A reaction mixture for sequencing contained $2 \mu \mathrm{L}$ PCR product, $1 \mu \mathrm{L}$ of the respective primer at a concentration of $10 \mathrm{pmol}, 3 \mu \mathrm{L}$ Big Dye (APPLIED BIOSYSTEMS, Foster City, USA), and distilled water to a final volume of $10 \mu \mathrm{L}$. For each sample, a set of mixtures of forward and reverse primers was prepared. PCR procedures for the sequencing were carried out in a T-gradient thermocycler (BIOMETRA, Göttingen, Germany). The PCR programme consisted of a denaturation at $96{ }^{\circ} \mathrm{C}$ for $30 \mathrm{~s}$, followed by 30 cycles of denaturation at $96{ }^{\circ} \mathrm{C}$ for 10 $\mathrm{s}$, annealing for $5 \mathrm{~s}$, and an extension for $4 \mathrm{~min}$ at $60^{\circ} \mathrm{C}$. The annealing temperature was $55^{\circ} \mathrm{C}$ for types $\mathrm{C}$ or $\mathrm{D}$, while for types $\mathrm{A}, \mathrm{B}$, $\mathrm{E}$, or $\mathrm{F}$ was $60^{\circ} \mathrm{C}$. Sequences obtained were analysed using the sequence analysis module SeqMan with the software package DNASTAR Lasergene (GATC, Konstanz, Germany). This was compared with GenBank entries offered by the National Center for Biotechnology Information (NCBI).

\subsection{Isolation of $C$. botulinum from PCR-positive samples}

Isolation of $C$. botulinum was carried out from the PCR-positive samples after sequencing of PCR products. Aliquots of $100 \mu \mathrm{L}$ of each enrichment culture in $\mathrm{CMM}, \mathrm{FAB}$, and $\mathrm{RCM}$ were transferred into tubes containing $5 \mathrm{~mL}$ fresh $\mathrm{FAB}$ for a further anaerobic incubation of $2 \mathrm{~d}$ at $35-37^{\circ} \mathrm{C}$. The cultures were streaked on FAAE and incubated under the same condition for $4 \mathrm{~d}$. Colonies showing positive 
lipase reaction were taken and inoculated into FAB tubes and incubated for $2 \mathrm{~d}$. Moreover, the colonies were Gram-stained and microscopically examined. These cultures were confirmed by PCR and MBA. The isolates were frozen at $-30^{\circ} \mathrm{C}$, lyophilized in a BETA 1 freeze-dryer (CHRIST, Osterode am Harz, Germany), and stored at $4{ }^{\circ} \mathrm{C}$.

\subsection{Polyacrylamide gel electrophoresis (PAGE)}

Polyacrylamide gel electrophoresis was used only for samples that showed nonspecific bands in agarose electrophoresis. A total of $10 \mathrm{~mL}$ of $6 \%$ polyacrylamide gel contains $8 \mathrm{~mL}$ of DNA-PAGE [480 mL 2xTBE buffer (Tris Borate EDTA, SIGMA, Deisenhofen, Germany), $98 \mathrm{~mL} 50 \%$ glycerol, and $240 \mathrm{~mL}$ deionised water]; $2 \mathrm{~mL}$ of $30 \%$ AA-Bis (BIO-RAD, München, Germany); $100 \mu \mathrm{L}$ of $10 \%$ ammonium persulfate; and $10 \mu \mathrm{L}$ of TEMED ( $\mathrm{N}, \mathrm{N}, \mathrm{N}^{\prime}, \mathrm{N}^{\prime}$-Tetramethylethylenediamine, SIGMA, Deisenhofen, Germany). The electrophoresis was carried out in 1XTBE loading buffer at a constant voltage of $100 \mathrm{~V}$ for $1 \mathrm{~h}$. After the PAGE the DNA fragments were stained using silver staining kit of ROTH (CARL ROTH, Karlsruhe, Germany), following the producer's instructions. For each gel a positive and a negative control were carried out in parallel.

Specific bands that were at the same position as the positive control on the agarose gel were cut out and put into $50 \mu \mathrm{L}$ of buffer EB overnight at $4{ }^{\circ} \mathrm{C}$. The buffer was taken out and purified using a QIAquick Gel Extraction Kit (QIAGEN, Düsseldorf, Germany). Briefly, three volumes of buffer QG were added to the DNA buffer, mixed well, and pipetted into a QIAquick Spin Column. After centrifugation at $10,000 \times g$ for $1 \mathrm{~min}$, the flow-through was discarded and $700 \mu \mathrm{L}$ buffer PE was added. The QIAquick Spin Column was centrifuged at the same speed for $1 \mathrm{~min}$. After discarding the flow-through, an additional centrifugation at $10,000 \times g$ for 1 min was carried out to remove the residual ethanol from the wash buffer PE. Finally, the QIAquick Spin Column was placed into a clean $1.5 \mathrm{~mL}$ microcentrifuge tube and $50 \mu \mathrm{L}$ buffer EB (10 mM Tris. $\mathrm{Cl}, \mathrm{pH}$ 8.5) was added. After one minute the column was centrifuged in the same way as that in the other steps. The purified 
DNA samples were stored at $-20^{\circ} \mathrm{C}$ until further analyses such as sequencing, PCR, or restriction enzyme analyses were performed.

\subsection{Statistical analysis}

The results were subjected to statistical analysis by using SAS (SAS/STAT User Guid, Version 8.1, CARY, NC, USA). Analyses of variance to yield the significance of differences in recovery of $C$. botulinum among types and between two enrichment media were conducted. 


\section{RESULTS}

\subsection{Spore production}

Strains A 2298, B 2299, D 2301, and F 2303 produced good yields of spores in MAB, SeM, and SM, respectively. The sporulation was $80-100 \%$. The first sporangia as well as spores were observed on the second day of incubation. However, these strains sporulated poorly in other media. No variation in ability to sporulate occurred in case of strain F 2303 in SM or in SM with dried hay added (SM-hay).

Sporulation up to $90 \%$ of strains C 2145 and E 2625 was obtained in FAAE, while other $\mathrm{C}$ and $\mathrm{E}$ strains produced lower than 30\%. Substitution of egg yolk by horse blood in FAAB resulted in markedly poor sporulation yield of strains $B$ 2299, C 2145, C 2279, E 2302, and F 2303.

After centrifugation of sporulation cultures, resuspension of the pellets in SSS for further transformation into the spore form from the vegetative cells obtained a marked increase (10-20\%) in sporulation of all strains. There was no loss of toxigenicity of the spores.

No spore or very poor sporulation was observed on BA and EYA and in RCM with dried hay added (RCM-hay). On BA, strain C 2300 produced up to 80\% spores on the third day of incubation. However, bioassay and PCR showed the loss of toxigenicity. 
The media with the highest sporulation yield of the different $C$. botulinum strains are shown in Table 10.

Table 10: Spore production of the $C$. botulinum strains in various media

\begin{tabular}{llccc}
\hline \multirow{2}{*}{ Strain } & Media & \multicolumn{2}{c}{ Incubation } & Sporulation rate \\
\cline { 3 - 4 } & & Time $(\mathrm{d})$ & Temperature $\left({ }^{\circ} \mathrm{C}\right)$ & $\mathbf{( \% )}$ \\
\hline A 2298 & TM & $2-4$ & $30-35$ & $90-100$ \\
B 2299 & MAB & $2-4$ & $35-37$ & $80-100$ \\
C 2145 & FAAE & $3-5$ & $35-37$ & $80-90$ \\
D 2301 & SeM & $2-4$ & $35-37$ & $90-100$ \\
E 2625 & FAAE & $3-5$ & $30-35$ & $70-90$ \\
F 2303 & SM & $4-7$ & $30-35$ & $80-100$ \\
\hline
\end{tabular}

\subsection{Enumeration of $C$. botulinum spores in spiked honey samples}

The number of each strain of $C$. botulinum in honey samples inoculated with individual type of spores estimated by the MPN-PCR method is shown in Table 11. There was a significant difference between the numbers of types $C$ and $D$ $(p<0.05)$. Type D was significantly different to types B and F, while type $C$ was significantly different to types $A$ and $E$. No significant difference in the number of types $A$ and $E$ as well as types $B$ and $F$. Type $D$ revealed the highest recovery, while type $\mathrm{C}$ had the lowest recovery.

In honey inoculated with spore mixtures of the $C$. botulinum types, $C$. botulinum type $E$ revealed the highest, whereas type $D$ the lowest number (Table 12).

There was a significant difference in MPN between the two types. No significant difference $(p>0.05)$ was obtained in the number of types $A, B, C$, and $F$. 
Table 11: Recovery of $C$. botulinum in honey samples artificially spiked with individual spore types (MPN g ${ }^{-1}$ )

\begin{tabular}{cccc}
\hline Type & $\mathbf{n}$ & \multicolumn{2}{c}{ MPN } \\
\cline { 3 - 4 } & & Mean* $^{\star}$ & SE* $^{*}$ \\
\hline A & 6 & $112,000^{\mathrm{ab}}$ & 35,000 \\
B & 6 & $66,000^{\mathrm{bc}}$ & 9,000 \\
C & 6 & $21,000^{\mathrm{c}}$ & 10,000 \\
D & 6 & $137,000^{\mathrm{a}}$ & 22,000 \\
E & 6 & $89,000^{\mathrm{ab}}$ & 17,000 \\
F & 6 & $59,000^{\mathrm{bc}}$ & 9,000 \\
\hline
\end{tabular}

$n$, number of samples; *, rounded figures; ${ }^{a b c}$ Means with different superscripts differ significantly $(p<0.05)$; $S E$, standard error

The number of recovered spores of $C$. botulinum estimated by MPN-PCR was similar to, or higher than the number of spiked spores (Fig. 1). Similar results were obtained in honey spiked with mixed spore types except for types B and D recovery rates were lower.

Table 12: Recovery of $C$. botulinum in honey samples artificially spiked with mixed spore types (MPN g ${ }^{-1}$ )

\begin{tabular}{|c|c|c|c|}
\hline \multirow[t]{2}{*}{ Type } & \multirow[t]{2}{*}{$\mathbf{n}$} & \multicolumn{2}{|c|}{ MPN } \\
\hline & & Mean* & SE* \\
\hline$A$ & 6 & $3,000^{a b}$ & 800 \\
\hline$B$ & 6 & $2,000^{a b}$ & 1,000 \\
\hline $\mathrm{C}$ & 6 & $2,000^{a b}$ & 1,000 \\
\hline $\mathrm{D}$ & 6 & $1,000^{b}$ & 200 \\
\hline$E$ & 6 & $4,000^{a}$ & 700 \\
\hline $\mathrm{F}$ & 6 & $2,000^{a b}$ & 400 \\
\hline
\end{tabular}

$n$, number of samples; *, rounded figures, $a b$, Means with different superscripts differ significantly $(p<0.05)$; SE, standard error 


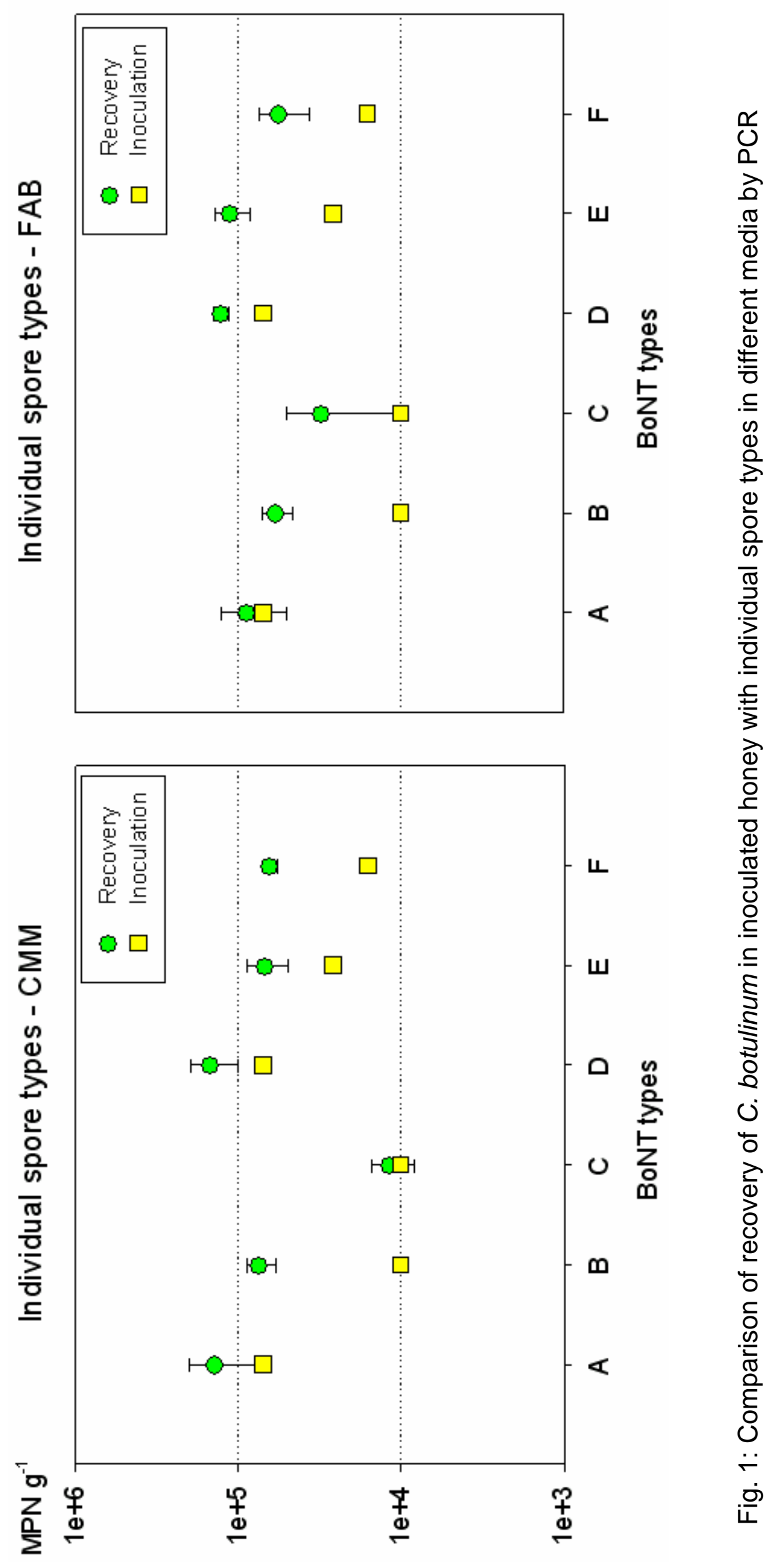




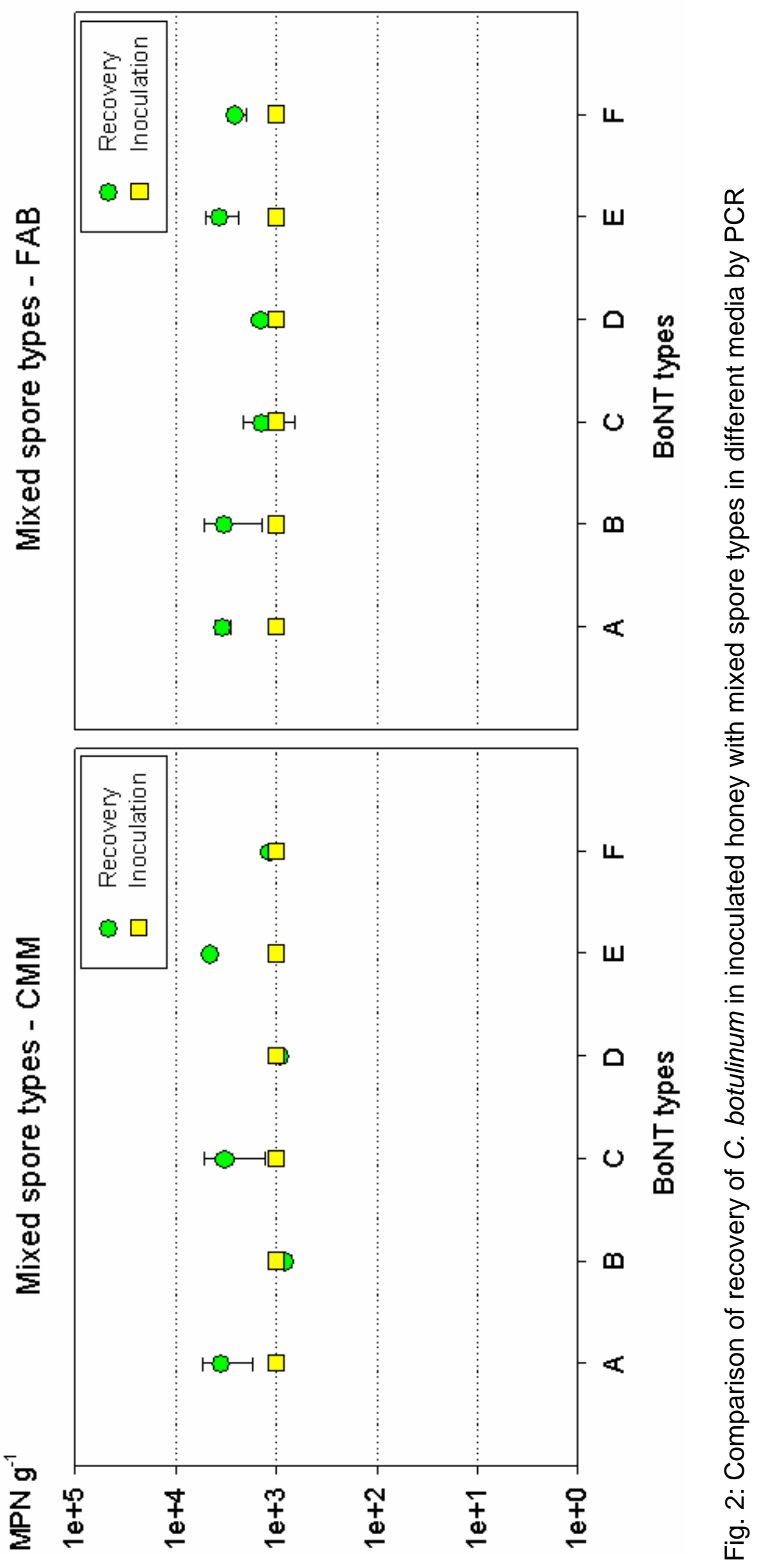


The confirmation using MBA was carried out with growing tubes at the highest dilution. All tubes that were PCR positive were also positive in MBAs.

Comparison of MPN of $C$. botulinum in honey samples inoculated with individual (group A) and mixed (group B) types of spores between the two enrichment media FAB and CMM was carried out. In both media, no difference in the number of $C$. botulinum in honey samples of group $A$ as well as group $B$ was estimated by MPN-PCR (Table 13 and 14). The two enrichment media CMM and $F A B$ revealed no significant difference in MPN of $C$. botulinum types $A$ to $F$ per gram of honey.

Table 13: Recovery of $C$. botulinum types $A$ to $F$ in honey samples inoculated with individual type of spores from different enrichment media (MPN $\left.g^{-1}\right)$

\begin{tabular}{llcc}
\hline \multirow{2}{*}{ Medium } & $\mathbf{n}$ & \multicolumn{2}{c}{ MPN } \\
\cline { 3 - 4 } & & Mean* & SE* $^{*}$ \\
\hline CMM & 18 & $83,000^{\mathrm{a}}$ & 16,000 \\
FAB & 18 & $78,000^{\mathrm{a}}$ & 11,000
\end{tabular}

$n$, number of samples; *, rounded figures; ${ }^{a}$ Means with the same superscripts are not significantly different ( $p>0.05$ ); SE, standard error

Table 14: Recovery of $C$. botulinum in honey samples spiked with mixed types of spores from different enrichment media (MPN g ${ }^{-1}$ )

\begin{tabular}{lccc}
\hline Media & $\mathbf{n}$ & \multicolumn{2}{c}{ MPN } \\
\cline { 3 - 4 } & & Mean* $^{\star}$ & SE* $^{*}$ \\
\hline CMM & 18 & $2,000^{\mathrm{a}}$ & 500 \\
FAB & 18 & $3,000^{\mathrm{a}}$ & 400 \\
\hline
\end{tabular}

$n$, number of samples; *, rounded figures; aMeans with superscripts are not significantly different ( $p>0.05)$; SE, standard error

\subsection{Incidence of $C$. botulinum spores in honey and infant food samples collected from Vietnam and Germany}

A total of 46 honey and infant food samples obtained from supermarkets in Germany and other 278 honey and infant food samples from retail stores in 
Vietnam were analysed for the presence of $C$. botulinum spores.

\subsubsection{Incidence of $C$. botulinum spores in honey and infant foods purchased in Vietnam}

The results of PCR analyses are presented in Table 15. Twenty of 179 (11.2\%) infant food samples and eight of 99 (8.1\%) honey samples were PCR positive. None of rice/soya bean infant foods was PCR positive. Only one of 35 (2.9\%) milk infant foods was positive. Five of 50 (10\%) pork/chicken samples were found PCR positive. The highest numbers of PCR-positive samples were obtained from fruit/vegetable and shrimp/fish infant foods, $20 \%$ and $23.3 \%$ respectively.

From the positive samples, $C$. botulinum type $C$ was most frequently obtained from fruit/vegetable and shrimp/fish infant foods. While types $B$ and $E$ were obtained from various types of infant foods, type $D$ was detected in honey samples with the most frequent number of samples (7 of 8 positive samples). More than one type was detected in eight infant food samples (3 types), in two other infant samples (2 types), and in two honey samples (2 types).

Table 15: Incidence of $C$. botulinum spores in honey and infant food samples in Vietnam by PCR

\begin{tabular}{llccc}
\hline \multicolumn{1}{c}{ Types of samples } & $\mathbf{n}$ & Positive (\%) & \multicolumn{1}{c}{ Type (*) } \\
\hline Honey & 99 & $8(8.1)$ & B (1), C (2), D (7) \\
\hline \multirow{4}{*}{ Infant Foods } & Pork/Chicken & 50 & $5(10.0)$ & B (5), E (4), F (2) \\
& Milk & 35 & $1(2.9)$ & B, E, F \\
& Shrimp/Fish & 30 & $7(23.3)$ & B (3), C (7), E (4) \\
& Rice/Soya bean & 29 & $0(0.0)$ & \\
\hline \multicolumn{2}{c}{ Total } & $\mathbf{2 7 8}$ & $\mathbf{2 8 ( 1 0 . 1 )}$ & \\
\hline
\end{tabular}

n, Number of samples tested; $\left(^{*}\right)$, Number of $C$. botulinum type detected 


\subsubsection{Incidence of $C$. botulinum spores in honey and infant foods purchased in Germany}

Eight of 46 samples collected in Germany harboured spores of $C$. botulinum type $B$ (Table 16). Of these samples, two honey samples were also type $E$ positive. All infant milk powder samples were negative, while 4 of 9 infant cereal formula, one of 8 potato purée, and one of 7 vegetable formula samples were positive for type B.

Table 16: Incidence of $C$. botulinum spores in honey and infant food samples in Germany by PCR

\begin{tabular}{lrcc}
\hline Types of samples & $\mathbf{n}$ & Positive (\%) & Type $\left(^{*}\right)$ \\
\hline Honey & 13 & $2(15.4)$ & B (2), E (2) \\
Infant cereal formula & 9 & $4(44.4)$ & B \\
Infant milk powder & 9 & $0(0.0)$ & \\
Potato purée & 8 & $1(12.5)$ & B \\
Vegetable formula & 7 & $1(14.3)$ & B \\
\hline Total & $\mathbf{4 6}$ & $\mathbf{8 ( 1 7 . 4 )}$ & \\
\hline
\end{tabular}

$\mathrm{n}$, Number of samples tested; $\left({ }^{*}\right)$, Number of $C$. botulinum type detected

\subsection{Mouse bioassays}

Mouse bioassays of the PCR-positive samples were conducted. Except two honey samples collected from Vietnam, all samples were negative regardless the incubation conditions, namely incubation time and temperature. The two honey samples, however, were then BMA negative when the mouse neutralisation test was carried out.

\subsection{Isolation of $C$. botulinum from PCR-positive samples}

Isolation of $C$. botulinum from PCR-positive samples was carried out by streaking on FAAE. C. botulinum was isolated from ten of 28 and one of eight PCR-positive samples from Vietnam and from German respectively (Table 17). However, these isolates were MBA negative. Type F PCR-positive samples presented proteolytic activity in CMM tubes. 
Table 17: C. botulinum isolates from PCR-positive samples*

\begin{tabular}{llc}
\hline Types of samples & Numbers of isolates \\
\hline Honey & & 5 \\
\hline Infant foods & Fruits/Vegetables & 2 \\
& Shrimp/Fish & 4 \\
\hline
\end{tabular}

*, all samples were from Vietnam except for a honey sample from Germany

\subsection{Incidence of $C$. botulinum spores in artificially inoculated honey and infant foods}

Honey and infant foods were artificially inoculated with a mixture containing an equal amount of $C$. botulinum spores to examine the validation of the method applied in the recent study. Fig. 3 presents the recovery rate of $C$. botulinum spores types A to $F$ in inoculated infant foods at various concentrations of spore inoculation.

At the concentration of 0.1 spores $\mathrm{g}^{-1}$ of infant foods, no $C$. botulinum spores could be detected, while at the concentration of 100 spores $\mathrm{g}^{-1} 100 \%$ of samples inoculated with C. botulinum spores of types B, C, D, E, and F and $66.67 \%$ of samples inoculated with type A were detectable. Types A, B, C, and E could be detected at the concentration of 1 spore $g^{-1}$, while for types $D$ and $F$ the minimum concentration for detection was at a level of 10 spores $\mathrm{g}^{-1}$. In honey inoculated with the mixture of $C$. botulinum spores types $A$ to $F$, all

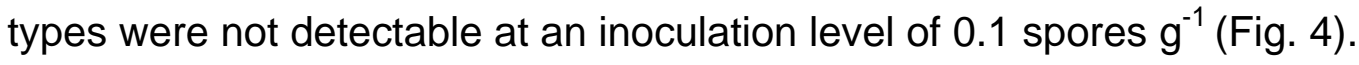
Except for type D, all types could be recovered at the concentration of 1 spore $\mathrm{g}^{-1}$ with a recovery rate of $14 \%$ up to $71 \%$. At the concentration of 100 spores $\mathrm{g}$ ${ }^{1}$ all types were recovered in $66 \%$ to $100 \%$ of the inoculated samples. The highest recovery rates were observed in type $\mathrm{E}$ followed by those in type $\mathrm{B}$. Type $D$ recovered in $11 \%$ of the spiked samples at the inoculation level of 10 spores $\mathrm{g}^{-1}$. 


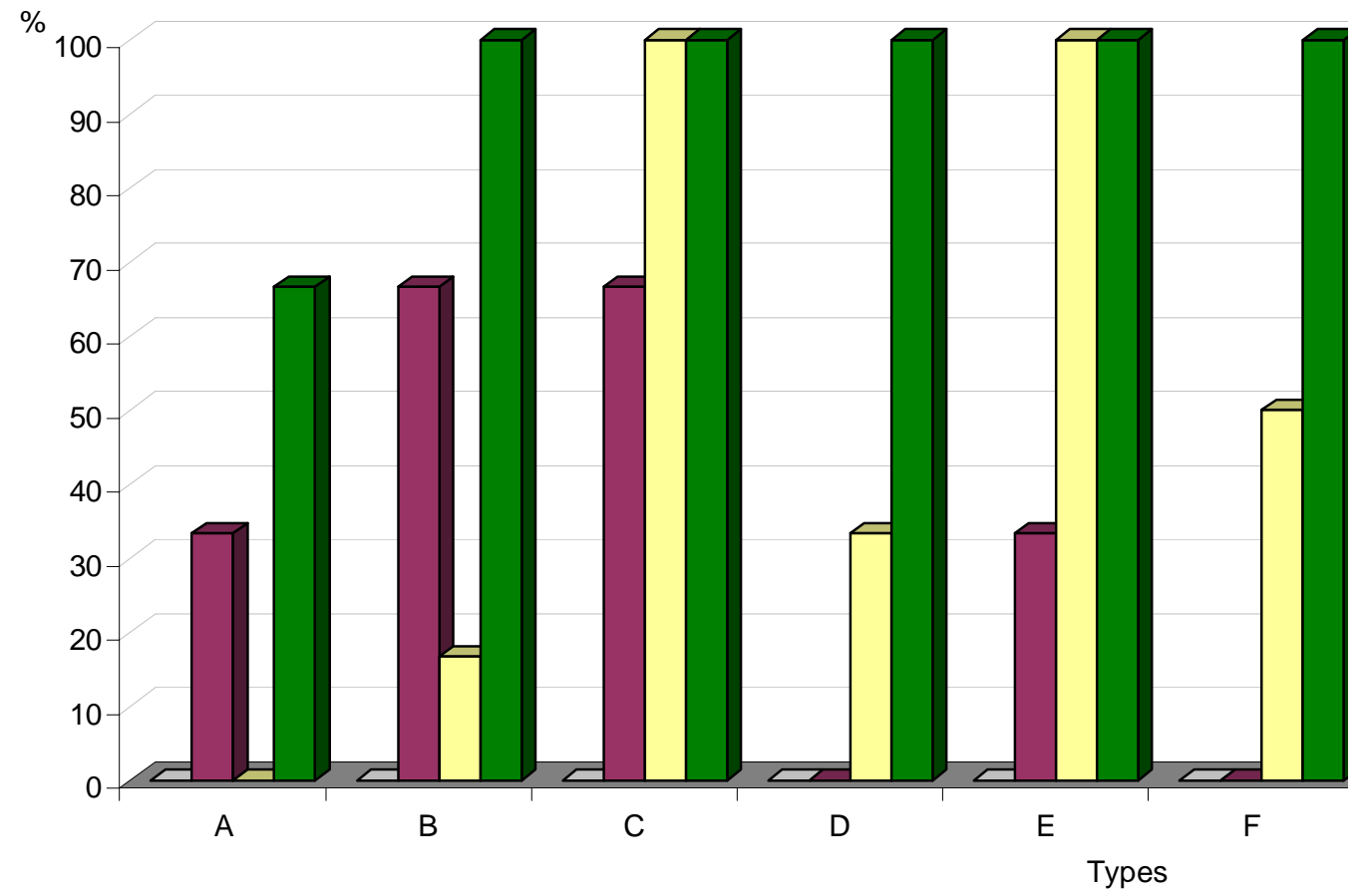

Fig. 3: Recovery rate of $C$. botulinum types in inoculated infant food samples with $0.1(\square), 1(\square), 10(\square)$, and $100(\square)$ spores $g^{-1}$.

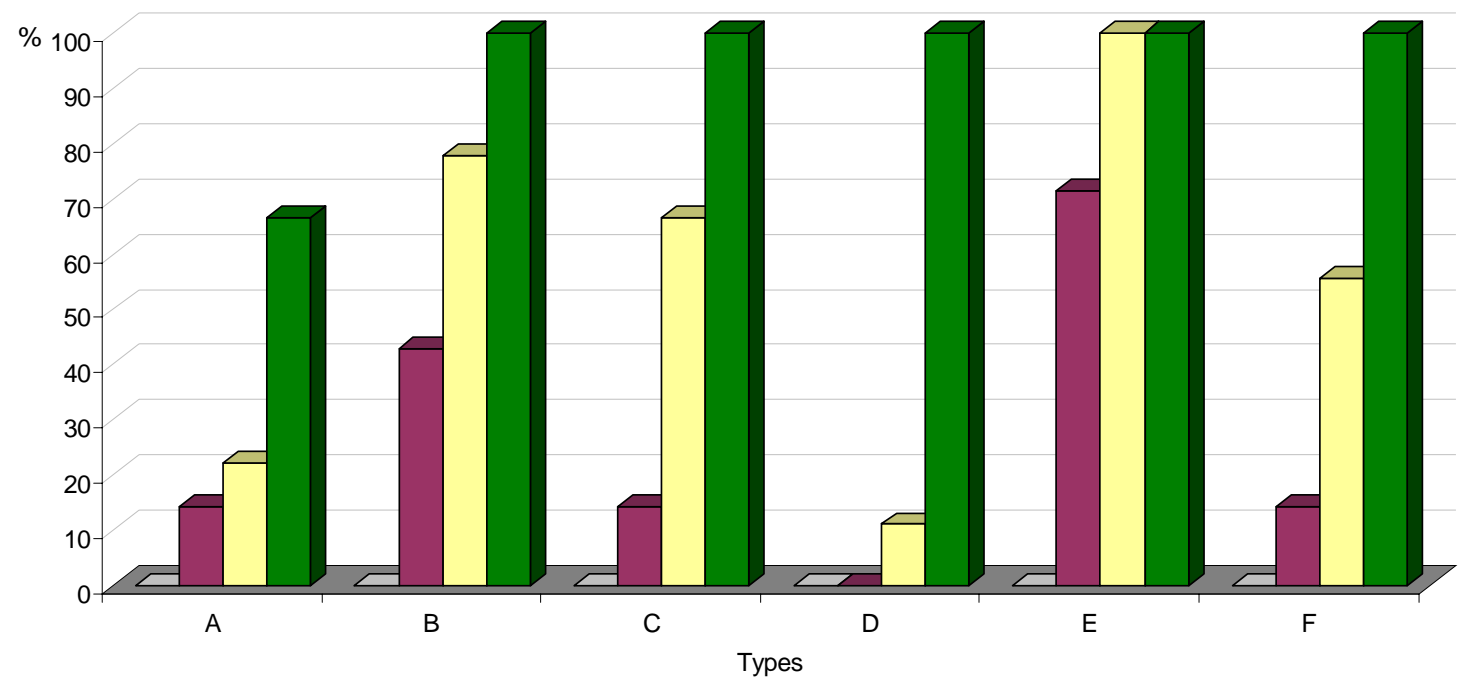

Fig. 4: Recovery rate of $C$. botulinum types in honey samples inoculated with $0.1(\square), 1(\square), 10(\square)$, and $100(\square)$ spores $g^{-1}$. 


\subsection{Restriction enzyme analysis}

From PCR-positive samples, PCR products were confirmed by digestion of the amplified fragments by restriction enzymes. Digestion patterns of the amplified fragments of $C$. botulinum strains and of honey and infant food samples are presented in Fig. 5-9. Digestion patterns of honey and infant food samples were in agreement with those of the $C$. botulinum strains used as positive control samples. However, there were no or very weak patterns obtained from some samples. Four of 20 type B samples and four of 13 type $E$ samples revealed no band. Six of 20 type B and three of 13 type $E$ samples revealed restriction patterns in only one of two parallel analyses of each sample.

\subsection{Sequence analysis}

Nucleotide sequencing analyses of amplified fragments of PCR-positive samples revealed similarity levels to $C$. botulinum neurotoxin types $B, C, D, E$, and F (Table 18). The sequences obtained from PCR fragments of PCRpositive samples were $98-100 \%$ identical to that of respective C. botulinum neurotoxin types.

Table 18: Nucleotide sequencing analysis of PCR-positive samples

\begin{tabular}{ccc}
\hline Type & Similarity level (\%) & GenBank accession number* \\
\hline B & 99.58 & M81186 \\
C & 99.95 & AB200364 \\
D & 99.95 & S49407 \\
E & 99.68 & X62089 \\
F & 98.13 & L35496
\end{tabular}




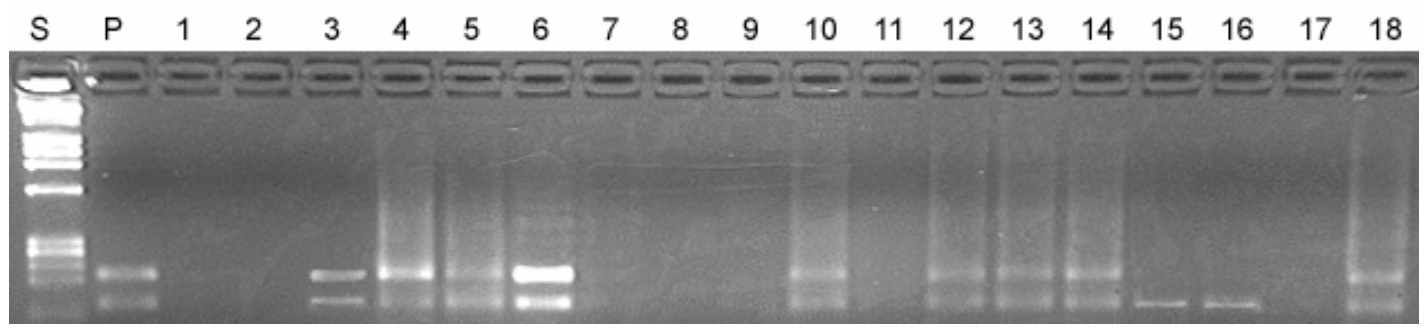

Fig. 5a: Digestion patterns of PCR products of type B with Dral. S, standard DNA; P, positive control; Lanes 1, 3, 4, 5, 6, 7, 9, 11, 13, 14, 15, 17, and 18, samples 1-13; Other lanes, repeated analysis of the samples.

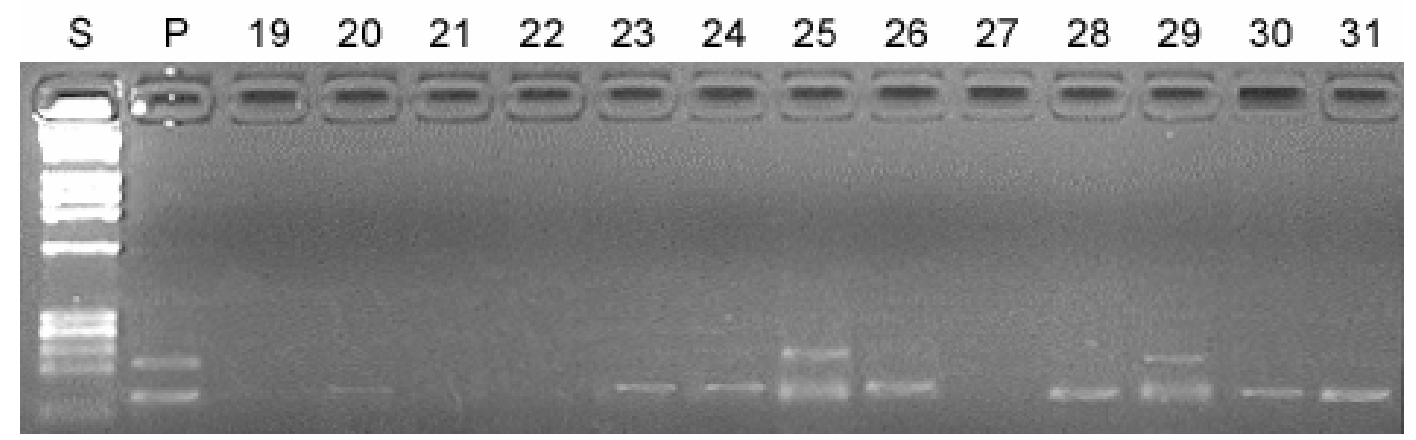

Fig. 5b: Digestion patterns of PCR products of type B with Dral. S, standard DNA; P, positive control; Lanes 19, 21, 23, 25, 27, 29, and 31, samples 1420; Other lanes, repeated analysis of the samples.

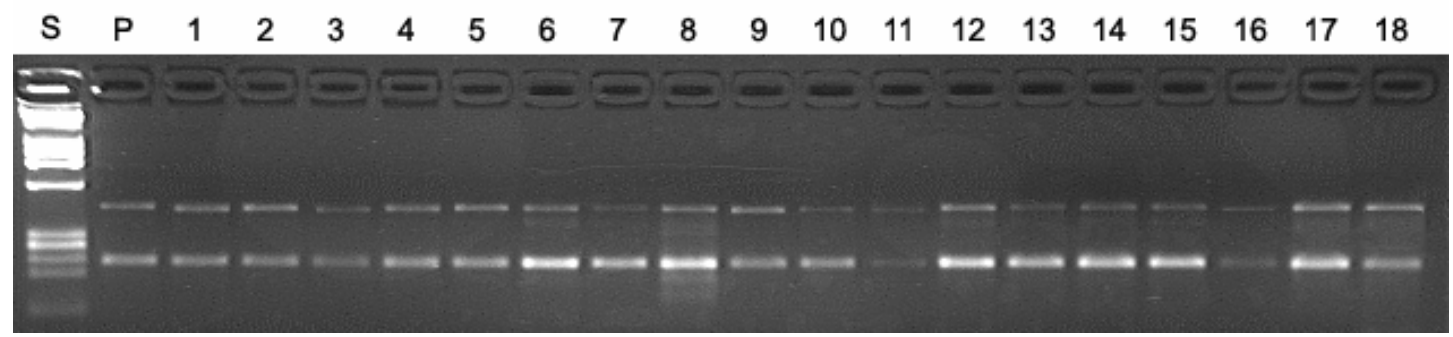

Fig. 6a: Digestion patterns of PCR products of type C with Mobll. S, standard DNA; P, positive control; Lanes 1, 2, 3, 4, 6, 7, 9, 10, 11, 12, 13, 14, 15, 17 and 18, samples 1-15; Other lanes, repeated analysis of the samples.

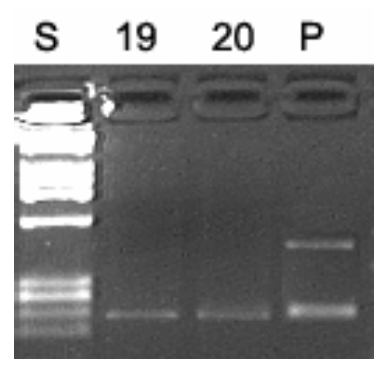

Fig. 6b: Digestion patterns of PCR products of type C with Mobll. S, standard DNA; P, positive control; Lane 19 and 20, sample 16. 


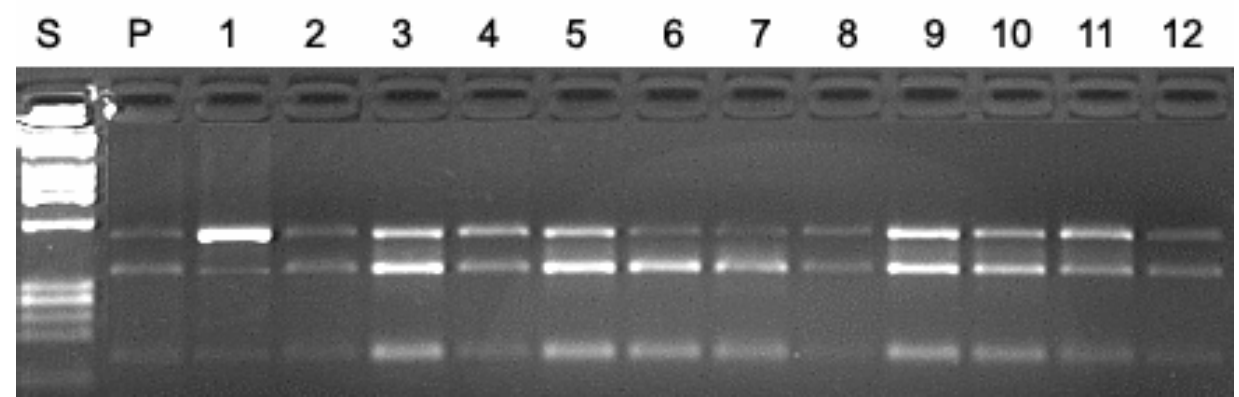

Fig. 7: Digestion patterns of PCR products of type D with Mobll. S, standard DNA; P, positive control; Lanes 1, 3, 4, 6, 8, 10, and 12, samples 1-7; Other lanes, repeated analysis of the samples.

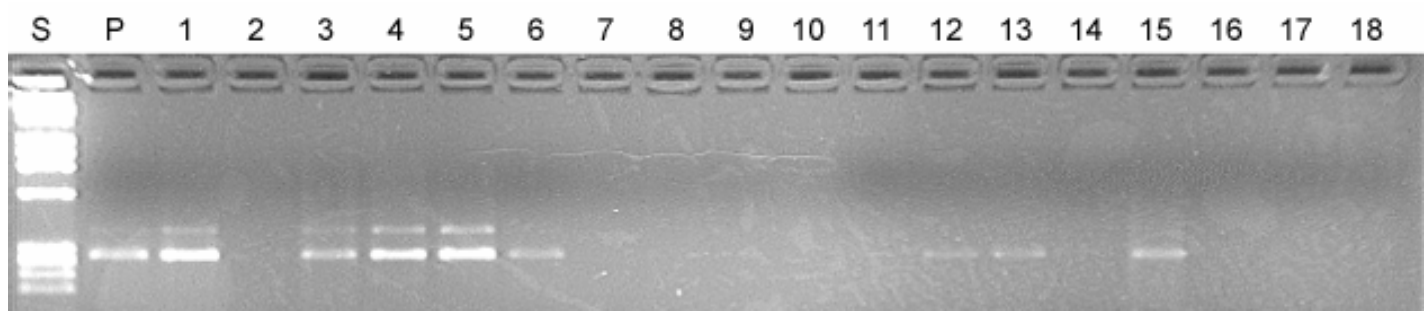

Fig. 8a: Digestion patterns of PCR products of type $E$ with Dral. S, standard DNA; P, positive control; Lanes 1, 3, 5, 6, 7, 9, 11, 13,15, and 17, samples 1-10; Other lanes, repeated analysis of the samples.

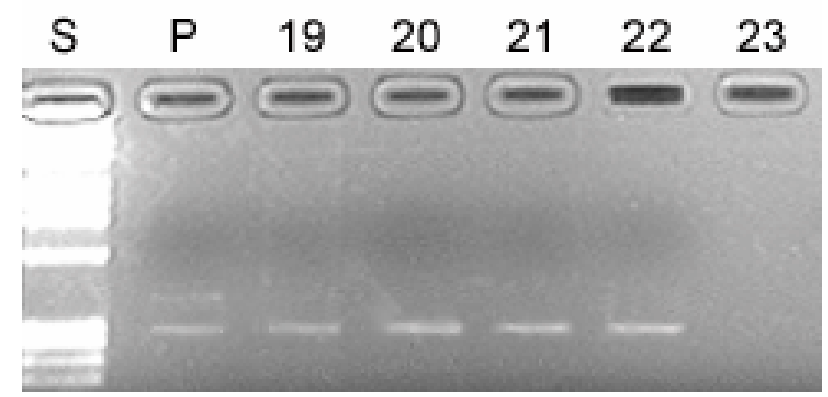

Fig. 8b: Digestion patterns of PCR products of type E with Dral. S, standard DNA; P, positive control; Lanes 19, 21, and 23, samples 11-13; Other lanes, repeated analysis of the samples. 


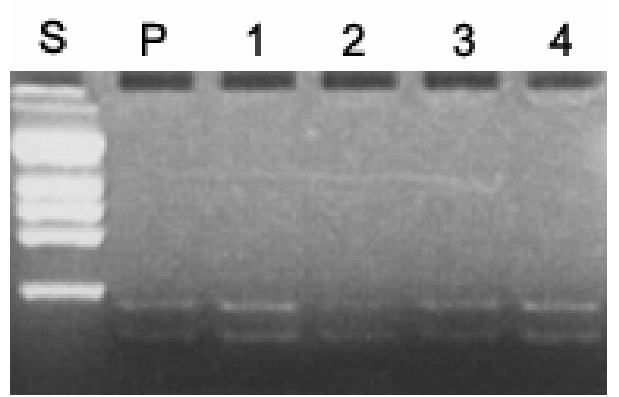

Fig. 9: Digestion patterns of PCR products of type $F$ with Dral. S, standard DNA; P, positive control; Lanes 1, 2, and 3, samples 1-3; Lane 4, repeated analysis of sample 3 . 


\section{DISCUSSION}

\subsection{Spore production}

For strain A 2298, shorter incubation time of sporulation in TM was observed in comparison to $C$. botulinum $62 \mathrm{~A}$ using the same amount of trypticase but with a substitution of peptone by $1.0 \%$ ammonium sulphate (Tsuji and Perkins, 1962). The medium used in this study was also simpler than that developed by Tsuji and Perkins. While very poor sporulation was obtained with all $C$ strains, strain D 2301 sporulated well in SeM, which was used for sporulation of $C$. botulinum type C in the study carried out by Segner et al. (1971).

The increased sporulation of all strains in SSS was observed, while toxigenicity of the $C$. botulinum spores was not affected. The detailed effect of SSS on sporulation and toxigenicity of $C$. botulinum spores was not reported in previous studies. Kihm et al. (1990) found that $C$. botulinum 113B sporulated well in media containing 0.01 to $1.0 \mathrm{mM} \mathrm{Fe}, \mathrm{Cu}, \mathrm{Mn}$, or $\mathrm{Zn}$.

Similar poor sporulation on BA was also reported by Roberts (1965). While in DSM spores were well produced by C. perfringens (Duncan and Strong, 1968), C. botulinum strains grew poorly and produced no spores. On BA, strain C 2300 produced up to $80 \%$ spores on the third day of incubation. However, bioassay and PCR showed the loss of toxigenicity.

Bacteria from stock cultures should be transferred into large volumes of medium, FAB in this study, before they are inoculated into sporulation media. This method brings a large number of cells to maturity and eventual sporulation at approximately the same time. Similar observation was reported by Perkins in production of different clostridia spores (1965).

\subsection{Enumeration of $C$. botulinum spores in spiked honey samples}

Compared to the numbers of $C$. botulinum spores inoculated in spiked honey samples, the MPN results were either the same or higher reflecting the high recovery rate of $C$. botulinum in both media CMM and FAB used. High recovery rates up to $100 \%$ or even higher than the inoculated number were obtained by 
MPN-PCR estimation of Listeria monocytogenes in fermented sausages (Martin et al., 2004) and of Vibrio parahaemolyticus in seafood (Miwa et al., 2003).

MPN method has been used for the enumeration of low levels of bacteria, especially bacteria in water. MPN method, however, unlike bacterial plate count, tends to yield a higher bacterial count (Eller et al., 1967; Peeler et al., 1992). Different researchers described quantification of microorganisms using MPNPCR technology in various types of samples: in soil (Fredslund et al., 2001), in water (Savill et al., 2001; Chern et al., 2004), and in food (Mantynen et al., 1997; Miwa et al., 2003; Martin et al., 2004). MPN-PCR was used to enumerate $C$. botulinum spores in soil amended with spiked compost (Gessler and Böhnel, 2006). A MPN-PCR protocol for detection and enumeration of $C$. botulinum types $A, B, E$, and $F$ in fish and sediment samples was developed by Hielm et al. (1996). A quantitative PCR-MPN analysis was applied for determination of $C$. botulinum types $A, B, E$, and $F$ in river lampreys caught in Finnish rivers (Merivirta et al., 2006). The technique was also applied for enumeration of $C$. botulinum spores in honey (Nevas et al., 2002). Enumeration of $C$. botulinum spores using the MPN-PCR method in this study was completed within $5 \mathrm{~d}$, or 8 $\mathrm{d}$ when further growing tubes were examined.

The method utilised a large amount of culture media and required much laboratory work for media preparation, pipetting, and conducting PCR with a large number of reactions. However, the MPN-PCR is a simple method and does not require high technological equipment that is not always available in developing countries like Vietnam. The advantage of the MPN-PCR method is that only viable and toxigenic $C$. botulinum spores in honey are enumerated by the multiple tube cultures and PCR detection. The PCR confirmation applied in MPN-PCR method yielded significant labour and time savings. Furthermore, compared to conventional MBA confirmation for quantification of C. botulinum in food samples using MPN method, which is followed by mouse bioassays (Sugiyama, 1978; Midura et al., 1979; Huhtanen et al., 1981; Nakano et al., 1990; Nakano and Sakaguchi, 1991), the MPN-PCR method is obviously more convenient and reliable, and avoids facilities as well as ethical issues using experimental animals. 


\subsection{Incidence of $C$. botulinum spores in honey and infant food samples collected from Vietnam and Germany}

A total of 46 honey and infant food samples obtained from supermarkets in Germany and other 278 honey and infant food samples from retail stores in Vietnam were analysed for the presence of $C$. botulinum spores.

Honey has been known to contain C. botulinum spores and considered a potential source of infant botulism (Midura and Arnon, 1976; CDC, 1998; Arnon et al., 1979; Midura et al., 1979). Other sweeteners used to supplement infant foods such as corn syrup and other syrups were also investigated (Kautter et al., 1982; Hauschild et al., 1988; Lilly et al., 1991). One of 354 light and one of 271 dark corn syrups were presumptively positive for type $C$. botulinum type $A$ spores, while subsequent testing of the entire contents of both bottles and all other 113 syrups were negative (Lilly et al., 1991). In a study analysing 150 honey, 43 syrup, and 40 dry cereal samples in the USA conducted by Hauschild et al. (1988), C. botulinum type A spores were detected in a honey sample associated with an infant botulism case and type $B$ in a sample of rice cereal. From ten categories of infant foods in the USA, including dry cereals, non-fat milk, pasteurised cow's milk, canned fruits and fruit juices, granulated cane sugar, fresh carrots, corn syrup, and honey, with a total of 910 samples, only two of 100 honey samples and eight of 40 corn syrup samples contained $C$. botulinum spores, type A and B, respectively (Kautter et al., 1982). However, C. botulinum was not detected in other infant food samples in New York City such as honey, dry cereal, canned formula, evaporated milk, non-fat dry milk, and canned baby food (Guilfoyle and Yager, 1983). The results obtained from these studies reflect the low incidence of $C$. botulinum spores in honey and infant food samples.

The incidence of $C$. botulinum spores in honey has been investigated in several studies applying various methods. The incidence obtained in this study was $8.1 \%$ in honey from Vietnam and $15.4 \%$ in honey from Germany. The results were consistent with those (11\%) reported by Nevas et al. (2002) applying PCR to detect 190 honey samples from Finnish and imported honey. Relatively similar incidence levels were obtained by other investigators: $7 \%$ in Argentina (Monetto et al., 1999), 7.1\% in Brazil (Schocken-Iturrino et al., 1999), 7.5\% in 
the USA (Huhtanen et al., 1981), 8.5\% in Japan (Nakano et al., 1990), 10\% in the USA (Midura et al., 1979), and 14\% in Denmark (Nevas et al., 2005a). Lower incidence from $0.9 \%$ to $3 \%$ was reported in other studies (Hauschild et al., 1988; Kautter et al., 1982; De Centorbi et al., 1997; Rall et al., 2003). One of 52 honey samples (1.9\%) in Germany examined by PCR was reported (Mäde et al., 2000). No C. botulinum spores were detected in 282 German honey samples (Flemming and Stojanowic, 1980; Hartgen, 1980). C. botulinum spores were not detected in one honey sample originating from Vietnam in the survey conducted by Delmas et al. (1994).

Honey and corn syrup in rare cases were considered the only foodstuffs associated with infant botulism until an infant botulism case derived from milk formula was described (Brett et al., 2005). The infant consumed infant formula milk powder, and C. botulinum type B was isolated from one of five unopened packets from the same batch. C. botulinum type A was detected from an opened container of dried rice pudding and C. botulinum type B from opened infant formula milk powder. It was suggested that multiple $C$. botulinum were present in both infant food and the intestine during infant botulism.

The results obtained from infant milk formula samples of the study are consistent with those in studies conducted by Kautter et al. (1982) and Guilfoyle and Yager (1983). Outbreaks of botulism involving milk and dairy products are rare. Less than $1 \%$ of the total number of foodborne botulism outbreaks associated with such products has been recorded since 1899. Type A, which was predominant, and type B have been associated with these outbreaks. Involvement of home and commercially prepared products in these outbreaks was equal (Collins-Thompson and Wood, 1993).

High incidence of $C$. botulinum spores was found in pork/chicken, fruits/vegetables, and shrimp/fish infant food samples from Vietnam and in infant cereal formula from Germany in comparison to other types of infant food samples tested. This raises the possibility of $C$. botulinum spore contamination of the ingredients encompassing all the main food groups like fish, meat, poultry, cereals, fruits, and vegetables. Fish has been reported in many food surveys to have the highest level of contamination with $C$. botulinum. Types $A, B, C, D, E$, and $F$ were identified in fish, shellfish, shrimp, and crabs. A large number of 
foodborne botulism outbreaks were associated with fish (Dodds, 1993a). Surveys for $C$. botulinum in meats and poultry showed low levels of contamination compared to fish, since contamination of farm environment is likely lower than aquatic environment (Dodds, 1993b). C. botulinum spores types A and B were detected in fruits and vegetables, particularly those harvested from the soil which was contaminated.

While types B, E, and $F$ were predominantly detected in honey samples, there have been few studies in which type A, C, and D were found. Type A was detected in honey from Argentina (Nakano et al., 1990; De Centorbi et al., 1994; De Centorbi et al., 1997; Monetto et al., 1999) and from Japan (Nakano et al., 1990), type $C$ in honey from China, and Japan (Nakano et al., 1990), and type D from Brazil (Schocken-Iturrino et al., 1999). Honey samples containing more than one type of $C$. botulinum spores in a sample were reported in various studies (Nakano et al., 1990).

There were two out-of-date infant food samples purchased in Vietnam, one of which was $C$. botulinum positive. These samples had the expiry dates of one year before the date on which they were purchased for analysis. The presence of the out-of-date foods raises a question about the control of foods purchased in markets in Vietnam.

Although the positive samples in this study were MBA negative for $C$. botulinum toxin, they were not recommended for feeding infants less than one year of age. Quorum sensing, a mechanism of cell-cell communication of bacteria with their peers as a result of bacterial population density has been reported (Withers and Nordstrom, 1998; Bassler, 1999; Hastings and Greenberg, 1999; Augustin et al., 2000; Gonzalez et al., 2001; Miller and Bassler, 2001). The important role of quorum sensing in food microbiology has been reviewed (Smith et al., 2004). Quorum sensing is used to regulate many diverse physiological activities including symbiosis, competence, antibiotic production, biofilm formation, and sporulation (Miller and Bassler, 2001). For pathogenic bacteria like C. botulinum the quorum sensing is also a way to coordinate production of virulence factors such as toxin. Foodborne pathogens such as E. coli and Salmonella typhimurium use quorum sensing to process cell density information and metabolic cues. The role of cell-cell-signalling by autoinducer 2 (AI-2) for toxin 
production in C. perfringens was described by Ohtani et al. (2002). Zhao et al. (2006) found evidence for signalling molecules providing the first step in characterising quorum sensing in $C$. botulinum. Little is known, however, on the role of quorum sensing in the growth, sporulation, and/or toxin production of $C$. botulinum present in food.

\subsection{PCR analyses}

The sensitivity of the multiplex PCR, using DNA templates from pure $C$. botulinum cultures, was 10 cells for type $B$ and 100 cells presenting in a reaction mixture for types $A, E$, and $F$. The enrichment of samples before PCR is required to obtain more reliable results due to normally low numbers of $C$. botulinum spores present in naturally contaminated samples (Lindström et al., 2001). PCR for type D using primers DS-11 and DS-22 could detect $2.5 \mathrm{pg}$ of DNA templates, approximately 875 cells (Takeshi et al., 1996). These protocols were found rapid, specific, and reliable for the detection of $C$. botulinum.

The detection of $C$. botulinum is markedly improved by means of the multiplex PCR assay. In our study, the DNA templates for the PCR assays were prepared using the NucleoSpin Tissue kits. This DNA extraction method showed marked improvement in PCR products obtained and visualised in agarose electrophoresis in comparison with the DNA extraction described in the PCR protocol developed by Lindström et al. (2001). In a preliminary study, the DNA extraction using NucleoSpin Tissue kits revealed clearer and less unspecific bands compared to the other DNA extraction method. There were also cases in which the former method revealed clear positive bands while no band was observed in samples prepared with the latter method.

A method for detection of $C$. botulinum in honey was developed by Mäde et al. (2000) applying PCR after enrichment. The amplified products were verified by DNA sequencing. The procedure was found easy to conduct without using animal experiment. However, only C. botulinum types A, B, E, F, and G were detected in this study.

The sensitivity of PCR used to detect $C$. botulinum types A, B, E, F, and G in food was compared to that of MBA, the correlation between the two methods was $95.6 \%$ for artificially contaminated food samples (Fach et al., 1995). The 
PCR method was found more rapid than MBA and avoided handling laboratory animals.

\subsection{Mouse bioassays}

Mouse bioassays of the PCR-positive samples were conducted. The prolongation of incubation time in MBA to increase the possibility of obtaining higher numbers of positive samples was explained by the presence of the small number of spores in the samples producing a low concentration of toxin that only affected the mice after a longer incubation time (Schocken-Iturrino et al., 1999). However, the results obtained in MBAs conducted in this study presented that all PCR-positive samples were not toxic. The concentration of $C$. botulinum spores in the samples might be so low to produce an efficient toxin level to the mice. In the study conducted by Fach et al. (1995), five of 66 samples inoculated with $C$. botulinum type B were PCR positive, but MBA negative, reflecting the possibility of PCR to detect the $C$. botulinum that was present but did not grow sufficiently to produce enough toxin to kill the mice. Another possible reason is the presence of silent genes in the $C$. botulinum spores detected. Franciosa et al. (1994) reported that genes encoding type B neurotoxin were detected by PCR in 43 of 79 strains of $C$. botulinum type A. However, only one of these strains produced a demonstrable type $B$ toxin. A confirmation of the presence of silent or unexpressed botulinum toxin type $B$ genes was conducted using PCR-restriction fragment length polymorphism analysis and specific oligonucleotide probes (Cordoba et al., 1995). The presence of silent genes clusters in many $C$. botulinum strains has been reported. Genes encoding type B botulinum neurotoxin in some type A strains of $C$. botulinum exhibiting no type B toxin activity were detected by Hutson et al. (1996). Further studies need to be conducted to investigate possibility of $C$. botulinum spores with silent toxin encoding genes in strains of other types present in honey and infant food samples.

\subsection{Isolation of $C$. botulinum from PCR-positive samples}

Isolation of $C$. botulinum from PCR-positive samples was carried out by streaking on FAAE. C. botulinum was isolated from only a part (11 of 36) of 
PCR-positive honey and infant food samples. The growth of other bacteria than that of $C$. botulinum demonstrated their inhibitory effect on the growth of $C$. botulinum. The presence of inhibitory bacteria resulting in the difficulty of $C$. botulinum isolation has been widely reported (Graham, 1978; Sandler et al., 1998; Böhnel and Lube, 2000). The lipase-positive isolates were found PCR positive, but MBA negative, demonstrating a possible toxicity loss. The toxicity loss in pure C. botulinum isolates was reported by Eklund et al. (1971). FAA modified with either horse blood or egg yolk, was found to be better for isolation of $C$. botulinum than BA and EYA, and recommended for use (Saeed, 2005).

\subsection{Incidence of $C$. botulinum spores in artificially inoculated honey and infant foods}

The method applied in this study detected 1 spore of $C$. botulinum in $1 \mathrm{~g}$ of honey and infant foods. It may allow detecting $C$. botulinum spores in naturally contaminated honey and infant samples. The dilution of samples with enrichment media before PCR analyses increased the possibility of detection of C. botulinum spores in the samples and reduced the concentration of inhibitory substances that might affect the germination and growth of $C$. botulinum spores and the PCR. The centrifugation and supernatant filtration (SF) before PCR developed by Nevas et al. (2002) detected 0.1 spores of types A and B C. botulinum in $1 \mathrm{~g}$ of honey, but required much laboratory work and equipment for centrifugation and filtration. The use of dialysis for enumeration of $C$. botulinum spores in honey was described by Sugiyama et al. (1978). The method requires much time and laboratory work. Two methods, dilution and centrifugation, were developed by Midura et al. (1979) for isolation of $C$. botulinum spores in honey. The two methods were followed by MBAs and mouse neutralisation tests. Both methods could detect seven to nine spores in $1 \mathrm{~g}$ honey.

\subsection{Restriction enzyme analysis}

The identification of PCR products of $C$. botulinum types $A$ to $F$ using restriction enzyme digestion profiles was performed by Takeshi et al. (1996). It was found that amplified products were easily confirmed by their digestion patterns. In our study, majority of PCR products showed similar restriction fragments to those of positive control samples. From the samples of type B, 11 of 20 samples 
revealed the same fragments as those of the positive sample. Five other samples revealed only one fragment, which could be in agreement with that of entry M81186. Only the 472-bp fragment could be shown, while the other two fragments with $68 \mathrm{bp}$ and $153 \mathrm{pb}$ were too small to be visualised on agarose gel. There was an agreement between the digested fragments of the positive control sample with those obtained from the type $\mathrm{C}$ samples. However, compared to the estimated digestion fragments of the entry X53751, restriction patterns obtained were partly different. Digestion patterns of PCR products of type $D$ with Mobll were in agreement with those of the positive control, but not in agreement with those of the entry S49407. Their sizes were between $310 \mathrm{bp}$ and $564 \mathrm{bp}$. In comparison with positive control, some PCR fragments of type E revealed different digestion fragments. However, they were in agreement in sizes and numbers of patterns with the estimated digestion fragments of $C$. botulinum type E X62089 from the sequence data of NCBI. The fragments obtained from samples of type $F$ were in agreement with those of positive control sample, but not in agreement with those of the entry L35496. In some cases, digestion patterns were different or no pattern was observed. The reason is that the concentration of PCR products might be too low or the size of the patterns obtained was so small that they could not be visualised on agarose gel. From our observation, the visualisation of restriction enzyme profiles on agarose gel is not optimal, especially for food samples that contain very low numbers of a target foodborne bacterium. To overcome this problem, polyacrylamide gel electrophoresis may be used.

\subsection{DNA sequencing analysis}

Although all of the PCR-positive samples, except two honey samples, were MBA negative, DNA sequences of their PCR products showed high level of sequence identity with GenBank entries for $C$. botulinum. The complete nucleotide sequences of the seven botulinum neurotoxin types type $A$ to $F$ have been analysed (Binz et al., 1990a; Binz et al., 1990b; Thompson et al., 1990; Kimura et al., 1990; Poulet et al., 1992; Whelan et al., 1992a; Whelan et al., 1992b; Willems et al., 1993; Hutson et al., 1994; Elmore et al., 1995). All the sequences were identical with those of the GenBank entries. Their positions 
were within the neurotoxin encoding genes. One honey sample, although it was type C PCR positive, revealed the sequence that was not identical with the reference $C$. botulinum strains. This sample was not examined by restriction enzyme analysis and considered negative for $C$. botulinum. 


\section{Conclusion}

The recent study achieved spore production of $C$. botulinum types $A$ to $F$ using various media, although none of the media used favoured sporulation of all $C$. botulinum types. The applied MPN-PCR method can be used to enumerate $C$. botulinum spores in honey despite the high concentration of sugar in honey. The enrichment media CMM and FAB were equally suitable for recovery of $C$. botulinum with similar yields. Further studies need to be conducted to assess the validity of the MPN-PCR method in naturally contaminated honey.

For detection of $C$. botulinum spores in honey and infant food samples, the dilution of samples in enrichment media ensured the germination and growth of the spores. It also reduced the concentration of inhibitory substances for PCR analyses. Therefore, the detection of $C$. botulinum spores using PCR analysis was improved. DNA sequencing analysis of PCR products allows confirmation of the amplified fragments and avoids handling laboratory animals.

Demand for convenient and minimally processed baby foods has been increasing worldwide. Spores of $C$. botulinum are likely to be present in raw materials used to produce baby foods, and are able to survive the production process of many of these products. Studies on C. botulinum and its spores in a wide category, as well as a large number of samples from soil, water, raw food materials, and foods should be conducted locally.

There have been no studies on $C$. botulinum spores in honey and infant foods in Vietnam and there is no information about infant botulism risk involved with consumption of honey and infant foods. Investigations on the presence of $C$. botulinum spores in honey and infant foods should be conducted on a broader basis. It should probably also be checked in other items normally fed to infants, including contamination levels of raw materials used in infant food processing.

In Vietnam, it is necessary to educate the general public about the causes and prevention not only of infant botulism, but also of foodborne and wound botulism. The public should be educated on preventive interventions such as effective 
processing and preparation of commercially and home-made foods; as well as canned and preserved foods; proper use of all canned foods; cessation of feeding honey to, and addition of honey to foods for infants less than 12 months; advice regarding the potential risk of $C$. botulinum; medical care for infected wounds and safe use of needles in drug addicts. Moreover, with recognition of the threat posed by bio-terrorism, botulism outbreaks due to intentional causes must be recognised and planned for. Careful epidemiological and law enforcement investigations play a vital role in determining the cause of a botulism outbreak.

Vietnam is now on its way to becoming a member of the World Trade Organisation (WTO). With the increasing trend of global food trading, the contamination of pathogenic bacteria like $C$. botulinum in honey, infant foods, and foods in general, poses a botulism risk to customers in many countries. The Vietnamese government should compulsorily establish new legislation for food quality control in Vietnam. With respect to the work of Vietnamese policy makers, this study calls for a new quality standard for honey and infant foods. All such products should be (systematically) examined for the presence of $C$. botulinum spores in addition to other aspects of quality. This will require a great change in Vietnamese food hygiene laws. 


\section{SUMMARY}

This study was carried out to develop a procedure for producing spore suspensions of different strains of $C$. botulinum $A, B, C, D, E$, and $F$ was developed by applying different media. Moreover, a MPN-PCR method was developed to enumerate $C$. botulinum spores in honey samples, targeting the neurotoxin encoding genes.

Another object of the study was the detection of viable C. botulinum spores in honey samples and infant foods purchased from retail stores and supermarkets in Ho Chi Minh City, Vietnam, and from retail supermarkets in Germany. The purpose of this survey was to determine if honey and infant foods in these market areas would present a potential threat to infants in Vietnam and Germany.

The first phase of the study was carried out producing spores of different strains of $C$. botulinum A, B, C, D, E, and F. This was carried out using different media to enumerate spores of these strains in honey samples. Different strains sporulated best in different media. Type A strain 2298 sporulated well in trypticase medium (TM), type B strain 2299 in modified Anellis Broth (MAB), type D 2301 in Segner Medium (SeM), type F 2303 in sporulation medium (SM), type C 2300 and type E 2625 sporulated well on Fastidious Anaerobe Agar with Egg Yolk (FAAE). The sporulation rate was 80-100\% in the liquid media and 70$90 \%$ on agar plates. The use of salt solution for sporulation (SSS) after harvesting the spores from the sporulation media increased the sporulation rate by $10-20 \%$, but did not affect the toxigenicity of the spores.

A MPN-PCR method was developed to enumerate C. botulinum spores in honey. Sterilised honey samples were spiked with a known number of spores of different strains of $C$. botulinum. Each strain was inoculated separately and there was also a mixture of all the strains. Two media, FAB and CMM, were used as enrichment media. The retrieved number of individual strains and mixed strain spores in the spiked samples after incubation was similar and proportional to the initial spore inoculation. This was regardless of the strain 
type, or if the sample had mixed strains of spores. The results were similar between the two enrichment media.

In the second phase, honey and infant food samples were collected from supermarkets in Ho Chi Minh City, Vietnam and in Göttingen, Germany. These were tested for the presence of $C$. botulinum spores using PCR. For confirmation of the amplified fragments, DNA sequencing, restriction enzyme reaction, and MBA were carried out.

Twenty of 179 (11.2\%) infant food samples and 8 of $99(8.1 \%)$ honey samples collected from Vietnam were PCR positive. The highest numbers of PCRpositive samples were shrimp/fish (23.3\%) and fruit/vegetable (20\%) infant foods. None of rice/soya bean infant foods was PCR positive. Out of 50 pork/chicken samples, five were found PCR positive (10\%). Only one of 35 (2.9\%) milk infant foods was positive.

C. botulinum type $\mathrm{C}$ was most frequently found in fruit/vegetable and shrimp/fish infant foods, while type D was the most commonly detected in honey samples. Types $B$ and $E$ were obtained from various types of infant foods. More than one type was detected in ten infant foods and in two honey samples.

Of 46 samples collected in Germany; eight, from which six were infant foods and two were honey samples, harboured spores of $C$. botulinum. All infant milk powder samples were negative, while four of nine infant cereal formula, one of eight potato purée, and one of seven vegetable formula samples were positive for type B C. botulinum. Two honey samples were found PCR positive for types $B$ and $E$.

Although all PCR-positive samples were MBA negative, comparison of the sequences of their amplified PCR products with published sequences of $C$. botulinum strains provided by the NCBI showed a high sequence homology of 98-100\%. One type C PCR-positive sample showed a sequence that was not identical with $C$. botulinum Gene Bank entries. Further studies need to be conducted to investigate the possibility of $C$. botulinum spores with silent toxin encoding genes in strains of other types present in honey and infant food samples. 


\section{ZUSAMMENFASSUNG}

Die Studie wurde durchgeführt, um ein Verfahren zu entwickeln, mit dem Sporen der unterschiedlichen C. botulinum Typen A, B, C, D, E und F in optimierten Medien hergestellt werden können. Eine Methode zum quantitativen Nachweis von C. -botulinum-Sporen in Honigproben wurde erarbeitet. Dieses Verfahren war die Grundlage für eine vergleichende Untersuchung über das Vorkommen von C. botulinum Sporen in Honig und Säuglingsnahrung. Proben dieser Lebensmittel wurden bei Einzelhändlern und Supermärkten in Ho Chi Minh Stadt, Vietnam und in Supermärkten in Deutschland gekauft. Das Ziel dieser Untersuchung war, festzustellen, ob Honig und Säuglingsnahrung eine mögliche Bedrohung für Säuglinge und Kleinkinder in Vietnam und Deutschland darstellen können.

Zunächst wurde die Sporenproduktion der unterschiedlichen C.-botulinumTypen A, B, C, D, E und F mit verschiedenen Nährmedien optimiert. Während Typ A in TM, Typ B in MAB, Typ D in SeM und Typ F in SM gut sporulierte, versporten Typ $C$ und Typ E besser auf FAAE. Die Versporungsrate lag 80$100 \%$ in den flüssigen Medien und bei $70-90 \%$ auf Nährbodenplatten. Wurden die Sporen nach der Ernte in SSS resuspendiert, war erhöhte sich die Versporungsrate um 10-20\%. Die Toxigenität der Sporen wurde nicht beeinflusst.

Eine MPN-PCR Methode wurde entwickelt, um C.-botulinum-Sporen quantitativ im Honig zu bestimmen. Autoklavierte Honigproben wurden mit einer definierten Anzahl an Sporen der unterschiedlichen C.-botulinum-Typen entweder mit jedem Typ einzeln oder mit einer Mischung aller Typen versetzt. Zwei Kulturmedien, FAB und CMM, wurden als Anreicherungsmedien verwendet. Die Zahl der wieder gefundenen Sporen entsprach der zugegebenen Menge, unabhängig davon, ob nur ein Typ oder die Sporenmischung eingesetzt worden war. Zwischen den beiden Anreicherungsmedien wurden keine signifikanten Unterschiede beobachtet.

Im zweiten Abschnitt wurde Honig und Säuglingsnahrung in Supermärkten in Ho Chi Minh Stadt, Vietnam, und in Deutschland gekauft und auf das 
Vorkommen von C.-botulinum-Sporen mittels PCR untersucht. Die amplifizierten Fragmente wurden durch Restriktionsenzymanalyse und DNASequenzierung verifiziert, die Kulturen im Mäusebioassay geprüft. Zwanzig von 179 (11.2\%) Proben der Säuglingsnahrung und 8 von 99 (8.1\%) der Honigproben, die in Vietnam gesammelt worden waren, waren in der PCR positiv. Die höchste Anzahl von PCR-positiven Proben fanden sich bei Garnelen-/Fisch- (23.3\%) und Obst-/Gemüse-Säuglingsnahrung (20\%), während keine der Reis-/Soja-Nahrungen PCR-positiv war. Von 50 Schweinefleisch-/Huhn-Säuglingsnahrungsproben waren 5 (10\%) PCR-positiv. Nur eine von 35 (2.9\%) Milch-Säuglingsnahrungsproben war positiv.

C. botulinum Typ C wurde am häufigsten in der Frucht/Gemüse- und der Garnelen/Fisch-Säuglingsnahrung gefunden, während Typ D in den Honigproben am häufigsten ermittelt wurde. Die Typen B und E wurden in verschiedenen Lebensmitteln gefunden. Mehr als ein Typ wurde in 10 Säuglingsnahrungs- und in zwei Honigproben nachgewiesen.

Acht (davon 6 Säuglingsnahrungs- und 2 Honigproben) von 46 in Deutschland gekauften Proben enthielten C.-botulinum-Sporen. Alle

Säuglingsmilchpulverproben waren negativ, während 4 der 9 Getreidenahrungsproben, eine von 8 Kartoffelpurée- und eine von 7 Gemüsenahrungsproben positiv für Typ B waren. Zwei Honigproben waren in der PCR positiv für Typen B und E.

Obwohl alle PCR-positiven Proben im Mäusebioassay negativ waren, zeigten die Sequenzen ihrer PCR-Produkte eine hohe Homologie von 98-100\% mit Datenbanksequenzen (GeneBank). Eine Säuglingsnahrung, die PCR-positiv für Typ C war, zeigte eine Sequenz, die nicht mit $C$. botulinum identisch war. Weitere Studien müssen durchgeführt werden, um ein mögliches Vorhandensein von C.-botulinum-Sporen mit stillen kodierenden Genen in Honig- und Säuglingsnahrungs-Proben zu untersuchen. 


\section{REFERENCES}

Ahn-Yoon, S., DeCory, T.R., Durst, R.A., 2004. Ganglioside-liposome immunoassay for the detection of botulinum toxin. Anal Bioanal Chem 378: $68-75$.

Aktories, K., Ankenbauer, T., Schering, B., Jakobs, K.H., 1986a. ADPribosylation of platelet actin by botulinum $\mathrm{C}_{2}$ toxin. Eur J Biochem 161: 155-162.

Aktories, K., Barmann, M., Ohishi, I., Tsuyama, S., Jakobs, K.H., Habermann, E.,1986b. Botulinum $C_{2}$ toxin ADP-ribosylates actin. Nature 322: 390-392. Aranda, E., Rodriguez, M.M., Asensio, M.A., Córdoba, J.J., 1997. Detection of Clostridium botulinum types $\mathrm{A}, \mathrm{B}, \mathrm{E}$ and $\mathrm{F}$ in foods by PCR and DNA probe. Lett Appl Microbiol 25: 186-190.

Arnon, S.S., 1980. Infant botulism. Ann Rev Med 31: 541-560.

Arnon, S.S., 1998. Infant botulism. In: Feigin, R.D., Cherry, J.D. (eds.) Textbook of pediatric infectious diseases, $4^{\text {th }}$ ed. Saunders, Philadelphia, pp. 15701577.

Arnon, S.S., Damus, K. Thompson, B., Midura, T.F., Chin, J., 1982. Protective role of human milk against sudden death from infant botulism. J Pediatr 100: 568-573.

Arnon, S.S., Damus, K., Chin, J., 1981. Infant botulism: epidemiology and relation to sudden infant death syndrome. Epidemiol Rev 3: 45-66.

Arnon, S.S., Midura, T.F., Clay, S.A., Wood, R.M., Chin, J., 1977. Infant botulism: epidemiological, clinical, and laboratory aspects. J Am Med Assoc 237: 1946-1951.

Arnon, S.S., Midura, T.F., Damus, K., Thomson, B., Wood, R.M., Chin, J., 1979. Honey and other environmental risk factors for infant botulism. J Pediatr 94: 331-336.

Arnon, S.S., Midura, T.F., Damus, K., Wood, R.M., Chin, J., 1978. Intestinal infection and toxin production by Clostridium botulinum as one cause of sudden infant death syndrome. Lancet 1: 1273-1277.

Arnon, S.S., Schechter, R., Inglesby, T.V., Henderson, D.A., Bartlett, J.G., Ascher, M.S., Eitzen, E., Fine, A.D., Hauer, J., Layton, M., Lillibridge, S., 
Osterholm, M.T., O'Toole, T., Parker, G., Perl, T.M., Russell, P.K., Swerdlow, D.L., Tonat, K., 2001. Botulinum toxin as a biological weapon: medical and public health management. J Am Med Asso 285: 1059-1070. Augustin, J.C., Brouillaud-Delattre, A., Rosso, L., Carlier, V., 2000. Significance of inoculum size in the lag time of Listeria monocytogenes. Appl Environ Microbiol 66: 1706-1710.

Aureli, P., Fenicia, L., Pasolini, B., Gianfranceschi, M., McCroskey, L., Hatheway, C., 1986. Two cases of type E infant botulism caused by neurotoxigenic Clostridium butyricum in Italy. J Infect Dis 154: 207-211.

Aureli, P., Franciosa, G., Fenicia, L., 2002. Infant botulism and honey in Europe: a commentary. Pediatr Infect Dis J 21: 866-868.

Bakheit, A.M., Ward, C.D., McLellan, D.L., 1997. Generalised botulism-like syndrome after intramuscular injections of botulinum toxin type A: a report of two cases. J Neurol Neurosurg Psychiatry 62: 198.

Balslev, T., Ostergaard, E., Madsen, I.K., Wandall, D.A., 1997. Infant botulism: the first culture-confirmed Danish case. Neuropediatrics 28: 287-288.

Barash, J.R., Tang, T.W., Arnon, S.S., 2005. First case of infant botulism caused by Clostridium baratii type $\mathrm{F}$ in California. J Clin Microbiol 43: 4280-4282.

Barr, J.R., Moura, H., Boyer, A.E., Woolfitt, A.R., Kalb, S.R., Pavlopoulos, A., McWilliams, L.G., Schmidt, J.G., Martinez, R.A., Ashley, D.L., 2005. Botulinum neurotoxin detection and differentiation by mass spectrometry. Emerg Infect Dis 11: 1578-1583. (http://www.cdc.gov/ncidod/eid/vol11no10/pdfs/04-1279.pdf; accessed on $30^{\text {th }}$ August, 2006)

Barsanti, J.A., 1990. Botulism. In: Greene, C.E. (eds.) Infectious diseases of the dog and cat. Philadelphia, W.B. Saunders Co., pp. 515-520.

Barsanti, J.A., Walser, M., Hatheway, C.L., Bowen, J.M., Crowell, W., 1978. Type C botulism in American foxhounds. J Am Vet Med Assoc 172: 809813.

Bassler, B.L., 1999. How bacteria talk to each other: regulation of gene expression by quorum sensing. Curr Opin Microbiol 2: 582-587. 
Behrens, S., Sukop, U., Böhnel, H., 1998. SID und Botulismus. Läßt sich ein Zusammenhang nachweisen? Deutsch-russisch-usbekisches Symposium über den plötzlichen Kindstod. Rechtsmed Forsch Ergeb 18: 121-126

Berry, P.R., Gilbert, R.J., Oliver, R.W.A., Gibson, A.A.M., 1987. Some preliminary studies on the low incidence of infant botulism in the United Kingdom. J Clin Pathol 40: 121.

Binz, T., Kurazono, H., Popoff, M.R., Eklund, M.W., Sakaguchi, G., Kozaki, S., Krieglstein, K., Henschen, A., Gill, D.M., Niemann, H., 1990a. Nucleotide sequence of the gene encoding Clostridium botulinum neurotoxin type D. Nucleic Acids Res 18: 5556.

Binz, T., Kurazono, H., Wille, M., Frevert, J., Wernars, K., Niemann, H., 1990 b. The complete sequence of botulinum neurotoxin type $A$ and comparison with other clostridial neurotoxins. J Biol Chem 265: 9153-9158.

Black, J.D., Dolly, J.O., 1987. Selective location of acceptors for botulinum neurotoxin A in the central and peripheral nervous system. Neuroscience 23: 767-779.

Blodgett, R., 2001. Most probable number from serial dilutions. Appendix 2. FDA. BAM. http://www.cfsan.fda.gov/ ebam/bam-a2.html (accessed on 11.01.03).

Böhnel, H., 1999. Botulism - eine vergessene Erkrankung? Berl Münch Tierärztl Wochenschr 112: 139-145.

Böhnel, H., 2003. Spore salt solution. Personal communication.

Böhnel H, Gessler F., 2005. Botulinum toxins-cause of botulism and systemic diseases? Vet Res Commun 29: 313-345. Review

Böhnel, H. and Lube, K., 2000. Clostridium botulinum and biocompost: a contribution to the analysis of potential health hazards caused by biowaste recycling. J Vet Med B 47: 785-795.

Böhnel, H., Behrens, S., Loch, P., Lube, K., Gessler, F., 2001a. Is there a link between infant botulism and sudden infant death? Bacteriological results obtained in Central Germany. Eur J Pediatr 160: 623-628.

Böhnel, H., Schwagerick, B., Gessler, F., 2001b. Visceral botulism - a new form of bovine Clostridium botulinum toxication. J Vet Med A 48: 373-383.

Bonventre, P.F., 1979. Absorption of botulinum toxin from the gastrointestinal tract. Rev Infect Dis 1: 663-667. 
Boroff, D.A., Shu-chen, G., 1973. Radioimmunoassay for Type A Toxin of Clostridium botulinium. Appl Microbiol 25: 545-549.

Boyer, A.E., Moura, H., Woolfitt, A.R., Kalb, S.R., McWilliams, L.G., Pavlopoulos, A., Schmidt, J.G., Ashley, D.L., Barr, J.R., 2005. From the mouse to the mass spectrometer: detection and differentiation of the endoproteinase activities of botulinum neurotoxins $A-G$ by mass spectrometry. Anal Chem 77: 3916-3924.

Braconnier, A., Broussolle, V., Perelle, S., Fach, P., Nguyen-The, C., Carlin, F., 2001. Screening for Clostridium botulinum type A, B, and E in cooked chilled foods containing vegetables and raw material using polymerase chain reaction and molecular probes. J Food Prot 64: 201-207.

Brett, M.M., McLauchlin, J., Harris, A., O'Brien, S., Black, N., Forsyth, R.J., Roberts, D., Bolton, F.J., 2005. A case of infant botulism with a possible link to infant formula milk powder: evidence for the presence of more than one strain of Clostridium botulinum in clinical specimens and food. J Med Microbiol 54: 769-776.

Broussolle, V., Alberto, F., Shearman, C., Mason, D., Botella, L., Nguyen-The, C., Peck, M., Carlin, F., 2002. Molecular and physiological characterisation of spore germination in Clostridium botulinum and C. sporogens. Anaerobe 8: 89-100.

Brown, L.W., 1984. Infant botulism. Pediatr Ann 13: 135, 140, 143, 146, and 148.

Byard, R.W., Moore, L., Bourne, A., Lawrence, A., Goldwater, P., 1992. Clostridium botulinum and sudden infant death syndrome: a 10 year prospective study. J Paediatr Child Health 28: 156-157.

Campbell, K.D., Collins, M.D., and East, A.K., 1993. Gene probes for identification of the botulinal neurotoxin gene and specific identification of neurotoxin types B, E, and F. J Clin Microbiol 31: 2255-2262.

Carlin, F., Peck, M., 1995. Growth and toxin production by non-proteolytic and proteolytic Clostridium botulinum in cooked vegetables. Lett Appl Microbiol 20: 152-156.

Carlin, F., Peck, M.W., 1996. Growth of and toxin production by nonproteolytic Clostridium botulinum in cooked pureed vegetables at refrigeration temperatures. Appl Environ Microbiol 62: 3069-3072. 
Cato, E.P., George, W.L., Finegold, S.M., 1986. Genus Clostridium. In: Sneath, P.H.A., Mair, N.S., Sharpe, M.E., Holt, J.G. (eds.) Bergey's Manual of Systematic Bacteriology. Williams \& Wilkins, Baltimore, Vol. 2, pp. 11411200.

CDC (Centers for Disease Control and Prevention) 1997. Case definitions for infectious conditions under public health surveillance. MMWR Morb Mortal Wkly Rep 46: 7-8.

CDC 1998. Botulism in the United States 1899-1996. Handbook for epidemiologists, clinicians, and laboratory workers. Centers for Disease Control and Prevention, Atlanta.

CDC 2003. Wound botulism among black tar heroin users-Washington, 2003. MMWR Morb Mortal Wkly Rep 52: 885-886.

Cherington, M., 1998. Clinical spectrum of botulism. Muscle Nerve 21: 701-710. Cherington, M., 2004. Botulism: update and review. Semin Neurol 24: 155-163. Chern, E.C., Tsai, Y.L., Olson, B.H., 2004. Occurrence of genes associated with enterotoxigenic and enterohemorrhagic Escherichia coli in agricultural waste lagoons. Appl Environ Microbiol 70: 356-362.

Chia, J.K., Clark, J.B., Ryan, C.A., Pollack, M., 1986. Botulism in an adult associated with food-borne intestinal infection with Clostridium botulinum. N Engl J Med 315: 239-241.

Chiao, D.J., Shyu, R.H., Hu, C.S., Chiang, H.Y., Tang, S.S., 2004. Colloidal gold-based immunochromatographic assay for detection of botulinum neurotoxin type B. J Chromatogr B Analyt Technol Biomed Life Sci 809: 37-41.

Collins-Thompson, D.L., Woo, D.S., 1993. Control in dairy products. In: Hauschild, A.H.W., Dodds, K.L. (eds.) Clostridium botulinum: ecology and control in foods. Marcel Dekker, pp. 261-277.

Cordoba, J.J., Collins, M.D., East, A.K., 1995. Studies on the genes encoding botulinum neurotoxin type $A$ of Clostridium botulinum from a variety of sources. System Appl Microbiol 18: 13-22.

Cox, N., Hinkle, R., 2002. Infant botulism. Am Fam Physician 65: 1388-1392.

Craven, K.E., Ferreira, J.L., Harrison, M.A., Edmonds, P., 2002. Specific detection of Clostridium botulinum types $\mathrm{A}, \mathrm{B}, \mathrm{E}$, and $\mathrm{F}$ using the polymerase chain reaction. J AOAC Int 85: 1025-1028. 
Dahlenborg, M., Borch, E., Radström, P., 2001. Development of a combined selection and enrichment PCR procedure for Clostridium botulinum types $B, E$, and $F$ and its use to determine prevalence in fecal samples from slaughtered pigs. Appl Environ Microbiol 67: 4781-4788.

De Centorbi, O.P., Alcaraz, L.E., Centorbi, H.J., 1994. [Bacteriologic analysis and detection of Clostridium botulinum spores in honey]. Rev Argent Microbiol 26: 96-100. (In Spanish).

De Centorbi, O.P., Satorres, S.E., Alcaraz, L.E., Centorbi, H.J., Fernandez, R., 1997. [Detection of Clostridium botulinum spores in honey]. Rev Argent Microbiol 29: 147-151. (In Spanish).

Delmas, C., Vidon, D.J. M., Sebald, M., 1994. Survey of honey for Clostridium botulinum spores in eastern France. Food Microbiol 11: 515-518.

Demarchi, J., Mourgues, C., Orio, J., Prevot, A.R., 1958. [Existence of type D botulism in man.] Bull Acad Natl Med 142: 580-582. (In French)

Desjardin, L.E., Chen, Y., Perkins, M.D., Teixeira, L., Cave, M.D., Eisenach, K.D., 1998. Comparison of the ABI 7700 system (TaqMan) and competitive PCR for quantification of IS6110 DNA in sputum during treatment of tuberculosis J Clin Microbiol 36: 1964-1968.

Dezfulian, M., 1999. Aerobic growth and toxigenicity of Clostridium botulinum types A and B. Folia Microbiol-Prague 44: 167-170.

Dezfulian, M., Bartlett, J.G., 1985a. Detection of Clostridium botulinum type B toxin in the presence of a lethal substance interfering with toxin neutralization. Diagn Microbiol Infect Dis 3: 105-112.

Dezfulian, M., Bartlett, J.G., 1985b. Selective isolation and rapid identification of Clostridium botulinum types A and B by toxin detection. J Clin Microbiol 21: 231-233.

Dezfulian, M., Hatheway, C., Yolken, R., Bartlett, J., 1984. Enzyme-linked immunosorbent assay for detection of Clostridium botulinum type $A$ and type B toxins in stool samples of infants with botulism. J Clin Microbiol 20: 379-383.

Dezfulian, M., McCroskey, L., Hatheway, C., Dowell, V., 1981. Selective medium for isolation Clostridium botulinum from human feces. J Clin Microbiol 13: 526-531. 
Dodds, K.L., 1993a. Clostridium botulinum in the environment. In: Hauschild, A.H.W., Dodds, K.L. (eds.) Clostridium botulinum: ecology and control in foods. Marcel Dekker, pp. 21-51.

Dodds, K.L., 1993b. Clostridium botulinum in foods. In: Hauschild, A.H.W., Dodds, K.L. (eds.) Clostridium botulinum: ecology and control in foods. Marcel Dekker, pp. 53-68.

Doellgast, G.J., Triscott, M., Beard, G., Bottoms, J., 1994. Enzyme-linked immunosorbent assay and enzyme-linked coagulation assay for detection of antibodies to Clostridium botulinum neurotoxins A, B, and E and solution -phase complexes with dual-label antibodies. J Clin Microbiol 32: 851-853.

Doellgast, G.J., Triscott, M.X., Beard, G.A., Bottoms, J.D., Cheng, T., Roh, B.H., Roman, M.G., Hall, P.A., Brown, J.E., 1993. Sensitive enzyme-linked immunosorbent assay for detection of Clostridium botulinum neurotoxins $A, B$, and $E$ using signal amplification via enzyme-linked coagulation assay. J Clin Microbiol 31: 2402-2409.

Dolimbek, B.Z., Jankovic,J., Atassi, M.Z., 2002. Cross reaction of tetanus and botulinum neurotoxins $A$ and $B$ and the boosting effect of botulinum neurotoxins $A$ and $B$ on a primary anti-tetanus antibody response. Immunol Invest 31: 247- 262.

Dowell, V.R., McCroskey, L., Hatheway, C., Lombard, G., Hughes, J., Merson, M., 1977. Coproexamination for botulinal toxin and Clostridium botulinum. J Am Med Asso 238: 1829-1832.

Dressler, D., Benecke, R., 2002. Erste Erfahrungen mit der klinischen Anwendung von Botulinum-Toxin Typ B. Nervenarzt 73: 194-198.

Dressler, D., Dirnberger, G., 2001. Botulinum toxin antibody testing: comparison between the immunoprecipitation assay and the mouse diaphragm assay. Eur Neurol 45: 257-260.

Dressler, D., Lange, M., Bigalke, H., 2005. Mouse diaphragm assay for detection of antibodies against botulinum toxin type B. Mov Disord 20: 117-119.

Duncan, C.L., Strong, D.H., 1968. Improved medium for sporulation of Clostridium perfringens. Appl Microbiol 16: 82-89. 
Durban, E., Goodnow, R., Grecz, N., 1970. Changes in resistance to radiation and heat during sporulation and germination of Clostridium botulinum. J Bacteriol 102: 590-592.

Eklund, M. W., Poysky, F. T., 1972. Activation of a toxic component of Clostridium botulinum types $C$ and D by trypsin. Appl Microbiol 24: 108113.

Eklund, M.W., 1993. Clostridium botulinum. In: Hauschild, A.W.H., Dodds, K.L. (eds.) Clostridium botulinum: ecology and control in foods. Marcel Dekker, New York. pp. 209-232.

Eklund, M.W., Dowell Jr., V.R. (eds.) 1987. Avian botulism: an international perspective. Charles C. Thomas, Springfield, III.

Eklund, M.W., Poysky, F.T., 1981. Relationship of bacteriophages to the toxigenicity of Clostridium botulinum and closely related organisms. In: Lewis, M. (eds.) Biomedical aspects of botulism. Academic Press, New York. pp. 93-107.

Eklund, M.W., Poysky, F.T., Wieler, D.I., 1967a. Characteristics of Clostridium botulinum type $\mathrm{F}$ isolated from the Pacific Coast of the United States. Appl Microbiol 15: 1316-1323.

Eklund, M.W., Poysky, F.T., Reed, S.M., 1972. Bacteriophage and the toxigenicity of Clostridium botulinum type D. Nat New Biol 235: 16-17.

Eklund, M.W., Poysky, F.T., Meyers, J.A., Pelroy, G.A., 1974. Interspecies conversion of Clostridium botulinum type $\mathrm{C}$ to Clostridium novyi type $\mathrm{A}$ by bacteriophage. Science 186: 456-458.

Eklund, M.W., Poysky, F.T., Mseitif, L.M., Strom, M.S., 1988. Evidence for plasmid-mediated toxin and bacteriocin production in Clostridium botulinum type G. Appl Environ Microbiol 54: 1405-1408.

Eklund, M.W., Poysky, F.T., Oguma, K., lida, H., Inoue, K., 1987. Relationship of bacteriophages to toxin and hemagglutinin production by Clostridium botulinum types $\mathrm{C}$ and $\mathrm{D}$ and its significance in avian botulism outbreaks. In: Eklund, M.W., Dowell Jr., V.R. (eds.) Avian botulism: an international perspective. Charles C. Thomas, Springfield, III. pp. 191-222.

Eklund, M.W., Poysky, F.T., Reed, S.M., Smith, C.A., 1971. Bacteriophage and the toxigenicity of Clostridium botulinum type C. Science 172: 480-482. 
Eklund, M.W., Wieler, D.I., Poysky, F.T., 1967b. Outgrowth and toxin production of nonproteolytic type B Clostridium botulinum at 3.3 to $5.6{ }^{\circ} \mathrm{C}$. J Bacteriol 93: 1461-1462.

Ekong, T., Gee, C., Blasi, J., Sesardic, D., 1997a. An alternative bioassay for botulinum neurotoxin type $A$ based on its endopeptidase activity. In: van Zutphen, L.F.M., Balls, M. (eds.) Animal alternatives, welfare, and ethics. Elsevier Science, London, pp. 1039-1044.

Ekong, T.A., Feavers, I.M., Sesardic, D., 1997b. Recombinant SNAP-25 is an effective substrate for Clostridium botulinum type A toxin endopeptidase activity in vitro. Microbiology 143: 3337-3347.

Eleopra, R., Tugnoli, V., Quatrale, R., Rossetto, O., Montecucco, C., 2004. Different types of botulinum toxin in humans. Mov Disord 19: 53-59. Eller, C., Rogers, L., Wynne, E.S., 1967. Agar concentration in counting Clostridium colonies. Appl Microbiol 15: 55-57.

Ellison, J.S., Kautter, J.A., 1970. Purification and some properties of two boticins. J Bacteriol 104:19-26.

Elmore, M.J., Hutson, R.A., Collins, M.D., Bodsworth, N.J., Whelan, S.M., Minton, N.P., 1995. Nucleotide sequence of the gene coding for proteolytic (group I) Clostridium botulinum type F neurotxin: genealogical comparison with other clostridial neurotoxins. Syst Appl Microbiol 18: 23-31.

Evancho, G.M, Ashton, D.H., Briskey, E.J., Schantz, E.J., 1973. A standardized reversed passive haemagglutination technique for the determination of botulinal toxin. J Food Sci 38: 764-767.

Fach, P., Gibert, M., Griffais, R., Popoff, M.R., 1996. Investigation of animal botulism outbreaks by PCR and standard methods. FEMS Immunol Med Microbiol 13: 279-285.

Fach, P., Gibert, M., Griffais, R., Guillou, J.P., and Popoff, M.R., 1995. PCR and gene probe identification of botulinum neurotoxin A-, B-, E-, F-, and Gproducing Clostridium spp. and evaluation in food samples. Appl Environ Microbiol 61: 389-392.

Fach, P., Hauser, D., Guillou, J.P., and Popoff, M.R., 1993. Polymerase chain reaction for the rapid identification of Clostridium botulinum type A strains and detection in food samples. J Appl Bacteriol 75: 234-239. 
Fach, P., Perelle, S., Dilasser, F., Grout, J, Dargaignaratz, C., Botella, L., Gourreau, J.M., Carlin, F., Popoff, M.R., Broussolle, V., 2002. Detection by PCR-enzyme-linked immunosorbent assay of Clostridium botulinum in fish and environmental samples from a coastal area in northern France. Appl Environ Microbiol 68: 5870-5876.

Fenicia, L., Da Dalt, L., Anniballi, F., Franciosa, G., Zanconato, S., Aureli, P., 2002. A case of infant botulism due to neurotoxigenic Clostridium butyricum type E associated with Clostridium difficile colitis. Eur J Clin Microbiol Infect Dis 21: 736-738.

Fenicia, L., Ferrini, A.M., Aureli, P., Pocecco, M., 1993. A case of infant botulism associated with honey feeding in Italy. Eur J Epidemiol 9: 671673.

Fernandez, P.S., Peck, M.W., 1997. A predictive model that describes the effect of prolonged heating at 70 to 80 degrees $C$ and incubation at refrigeration temperatures on growth and toxigenesis by nonproteolytic Clostridium botulinum. J Food Prot 60: 1064-1071.

Fernández, R.A., Ciccarelli, A.S., de Centorbi, O.N.P., Centorbi, H., Rosetti, F.A., de Jong, L.I.T., Demo, N., 1999. Infant botulism in Argentina, 19821997. Anaerobe 5: 177-179.

Ferrari, N.D. $3^{\text {rd }}$ and Weisse, M.E., 1995. Botulism. Adv Pediatr Infect Dis 10: 81-91.

Ferreira, J.L., 2003. Detection of botulinal neurotoxins $A, B, E$, and $F$ by amplified enzyme-linked immunosorbent assay: collaborative study. J AOAC Int 86: 314-331.

Ferreira, J.L., Eliasberg, S.J., Edmonds, P., Harrison, M.A., 2004. Comparison of the mouse bioassay and enzyme-linked immunosorbent assay procedures for the detection of type A botulinal toxin in food. J Food Prot 67: 203-206.

Ferreira, J.L., Hamdy, M.K., McCay, S.G., Zapatka, F.A., 1990. Monoclonal antibody to type F Clostridium botulinum toxin. Appl Environ Microbiol 56: 808-811.

Ferreira, J.L., Hamdy, M.K., Zapatka, F.A., Hebert, W.O., 1981. Immunodiffusion method for detection of type A Clostridium botulinum. Appl Environ Microbiol 42: 1057-1061. 
Flemming, R., Stojanowic, V., 1980. Untersuchungen von Bienhonig auf Clostridium botulinum-Sporen. Arch Lebensmittelhyg. 31: 179-180.

Fox, C.K., Keet, C.A., Strober, J.B., 2005. Recent advances in infant botulism. Pediatr Neurol 32: 149-154.

Franciosa, G., Ferreira, J.L., Hatheway, C.L., 1994. Detection of type A, B, and $E$ botulism neurotoxin genes in Clostridium botulinum and other Clostridium species by PCR: evidence of unexpected type B toxin genes in type A toxigenic organisms. J Clin Microbiol 32: 1911-1917.

Frankovich, T.L., Arnon, S., 1991. Clinical trial of botulism immune globulin for infant botulism. West J Med Surg 154: 103.

Fredslund, L., Ekelund, F., Jacobsen, C.S., Johnsen, K., 2001. Development and application of a most-probable-number-PCR assay to quantify flagellate populations in soil samples. Appl Environ Microbiol 67: 16131618.

Gaze, J.E., Brown, K.L., 1988. The heat resistance of Clostridium botulinum 213B over the temperature range $120-140^{\circ} \mathrm{C}$. Int J Food Sci Technol 23: 373-378.

Gessler, F., Böhnel, H., 2003. Nachweis von Botulinum-Neurotoxinen - ein methodischer Über- und Ausblick. Tierärztl Umschau 58: 1-5.

Gessler, F., Böhnel, H., 2006. Persistence and mobility of a spore population introduced to soil with spiked compost. FEMS: 1-10.

Gessler, F., Hampe, K., Böhnel, H., 2005. Sensitive detection of botulinum neurotoxin types $C$ and $D$ with an immunoaffinity chromatographic column test. Appl Environ Microbiol 71: 7897-7903.

Gessler, F., Hampe, K., Schmidt, M., Böhnel, H., 2006. Immunomagnetic beads assay for the detection of botulinum neurotoxin types $C$ and $D$. Diagn Microbiol Infect Dis [Epub ahead of print]

Ghanem FM, Ridpath AC, Moore WE, Moore LV., 1991. Identification of Clostridium botulinum, Clostridium argentinense, and related organisms by cellular fatty acid analysis. J Clin Microbiol 29: 1114-1124.

Gill, D.M., 1982. Bacterial toxins: a table of lethal amounts. Microbiol Rev 46: 86-94.

Gimenez, J.A., Sugiyama, H., 1988. Comparison of toxins of Clostridium butyricum and Clostridium botulinum type E. Infect Immun 56: 926-929. 
Glasby, C., Hatheway, C.L., 1985. Isolation and enumeration of Clostridium botulinum by direct inoculation of infant fecal specimens on egg yolk agar and Clostridium botulinum isolation media. J Clin Microbiol 21: 264-266.

Gonzalez, I., Garcia, T., Fernandez, A., Sanz, B., Hernandez, P.E., Martin, R., 1999. Rapid enumeration of Escherichia coli in oysters by a quantitative PCR-ELISA. J Appl Microbiol 86: 231-236.

Gonzalez, R.H., Nusblat, A., Nudel, B.C., 2001. Detection and characterization of quorum sensing signal molecules in Acinetobacter strains. Microbiol Res 155: 271-277.

Goodnough, M.C., Hammer, B., Sugiyama, H., Johnson, E.A., 1993. Colony immunoblot assay of botulinal toxin. Appl Environ Microbiol 59: 23392342.

Goonetilleke, A., Harris, J.B., 2004. Clostridial neurotoxins. J Neurol Neurosurg Psychiatry 75: iii35-iii39.

Graham, J.M., 1978. Inhibition of Clostridium botulinum type $C$ by bacteria isolated from mud. J Appl Bacteriol 45: 205-211.

Griffin, P.M., Hatheway, C.L., Rosenbaum, R.B., Sokolow, R., 1997. Endogenous antibody production to botulinum toxin in an adult with intestinal colonization botulism and underlying Crohn's disease. J Infect Dis 175: 633-637.

Guilfoyle, D.E., Yager, J.F., 1983. Survey of infant foods for Clostridium botulinum spores. J Assoc Off Anal Chem 66: 1302-1304.

Gunnison, G.B., Meyer, K.F., 1929. The occurrence of non-toxic strains C. parabotulinum. J Infect Dis 34: 79-80.

Gutierrez, R., Garcia, T., Gonzalez, I., Sanz, B., Hernandez, P.E., Martin, R., 1997. A quantitative PCR-ELISA for the rapid enumeration of bacteria in refrigerated raw milk. J Appl Microbiol 83: 518-523.

Gutteridge, C.S., Mackey, B.M., Norris, J.R., 1980. A pyrolysis gas-liquid chromatography study of Clostridium botulinum and related organisms. J Appl Bacteriol 49: 165-174.

Hall, J.D., McCroskey, L., Pincomb, B., Hatheway, C., 1985. Isolation of an organism resembling Clostridium baratii which produces type $\mathrm{F}$ botulinal toxin from an infant with botulism. J Clinic Microbiol 21: 654-655. 
Hallis, B., James, B.A., Shone, C.C., 1996. Development of novel assays for botulinum type $A$ and $B$ neurotoxins based on their endopeptidase activities. J Clin Microbiol 34: 1934-1938.

Hanna, P.A., Jankovic, J., Vincent, A., 1999. Comparison of mouse bioassay and immunoprecipitation assay for botulinum toxin antibodies. J Neurol Neurosurg Psychiatry 66: 612-616.

Hartgen, H., 1980. Untersuchungen von Honigproben auf Botulinustoxin. Arch Lebensmittelhyg 31: 177-178.

Hastings, J.W., Greenberg, E.P., 1999. Quorum sensing: the explanation of a curious phenomenon reveals a common characteristic of bacteria. $\mathrm{J}$ Bacteriol 181: 2667-2668.

Hatheway, C.L., 1995. Botulism: The present status of the disease. Curr Topics Microbiol Immunol 195: 55-75.

Hatheway, C.L., 1988. Botulism. In: Balows, A., Hausler, W.J., Ohashi, Jr.M., Turano, A. (eds.) Laboratory diagnosis of infectious diseases: principles and practice. Vol 1: Bacterial, mycotic, and parasitic diseases. Springer, pp. 111-133.

Hatheway, C.L., 1993. Clostridium botulinum and other clostridia that produce botulinum neurotoxin. In: Hauschild, A.H.W., Dodds, K.L. (eds.) Clostridium botulinum: ecology and control in foods. Marcel Dekker, pp. 320

Hauschild, A.H.W., Gauvreau, L., Black, A.W., 1983. Botulism in Canada summary for 1982. Can Dis Weekly Rep 9: 14-53.

Hauschild, A.H., Hilsheimer, R., 1977. Enumeration of Clostridium botulinum spores in meats by a pour-plate procedure. Can J Microbiol 23: 829-832.

Hauschild, A.H.W., 1989. Clostridium botulinum. In: Doyle, M.P. (eds.)

Foodborne bacterial pathogens. Marcel Dekker, pp. 112-189.

Hauschild, A.H.W., 1990. C. botulinum toxins. Int J Food Microbiol 10: 113-124. Hauschild, A.H.W., 1993. Epidemiology of human foodborne botulism. In:

Hauschild, A.H.W., Dodds, K.L. (eds.) Clostridium botulinum: ecology and control in foods. Marcel Dekker, pp. 69-104.

Hauschild, A.H.W., Gauvreau, L., 1985. Food-borne botulism in Canada, 197184. Can Med Assoc J 133: 1141-1146. 
Hauschild, A.H.W., Hilsheimer, R., Weiss, K.F., Burke, R.B., 1988. Clostridium botulinum in honey, syrups, and dry infant cereals. J. Food Prot 51: 892894.

Heitefuß, S., 1991. Untersuchungen zur Identifizierung von aeroben, anaeroben und fakultativ anaeroben Bakterien mit gaschromatographischen Methoden. Diss. Sc. Agr. Göttingen, pp. 124.

Hielm, S., Hyytia, E., Andersin, A.B., and Korkeala, H., 1998. A high prevalence of Clostridium botulinum type $\mathrm{E}$ in Finnish freshwater and Baltic Sea sediment samples. J Appl Microbiol 84: 133-137.

Hielm, S., Hyytia, E., Ridell, J., Korkeala, H., 1996. Detection of Clostridium botulinum in fish and environmental samples using polymerase chain reaction. Int J Food Microbiol 31: 357-365.

Higgins, J.A., Ezzell, J., Hinnebusch, B.J., Shipley, M., Henchal, E.A., Ibrahim, M.S., 1998. 5' nuclease PCR assay to detect Yersinia pestis. J Clin Microbiol 36: 2284-2288.

Hoffman, H.J., Damus, K., Hillman, L., Krongrad, E., 1988. Risk factors for SIDS. Results of the National Institute of Child Health and Human Development SIDS Cooperative Epidemiological Study. Ann N Y Acad Sci 533: $13-30$.

Huhtanen, C.N., Knox, D., Shimanuki, H., 1981. Incidence and origin of Clostridium botulinum spores in honey. J Food Protect 44: 812-814. Huhtanen, C.N., Whiting, R.C., Miller, A.J., Call, J.E., 1992. Qualitative correlation of the mouse neurotoxin and enzyme-linked immunoassay for detecting Clostridium botulinum types A and B toxins. J Food Saf 12: 119127.

Hutson, R.A., Collins, M.D., East, A.K., Thompson, D.E., 1994. Nucleotide sequence of the gene coding for non - proteolytic Clostridium botulinum type B neurotoxin: comparison with other clostridial neurotoxins. Curr Microbiol 28: 101-110.

Hutson, R.A., Zhou, Y., Collins, M.D., Johnson, E.A., Hatheway, C.L., Sugiyama, H., 1996. Genetic characterization of Clostridium botulinum type A containing silent type B neurotoxin gene sequences. J Biol Chem 271: 10786-10792. 
Hyytia, E., Bjorkroth, J., Hielm, S., Korkeala, H., 1999. Characterisation of Clostridium botulinum groups I and II by randomly amplified polymorphic DNA analysis and repetitive element sequence-based PCR. Int J Food Microbiol 8: 179-189.

ICMSF (International Commission on Microbiological Specifications for Foods). 1996. Clostridium botulinum. Chapter 5. In: Microorganisms in foods: microbiological specifications for food pathogens. Blackie Academic \& Professional, London, England, pp. 66-111.

Inoue, K., lida, H., 1968. Bacteriophages of Clostridium botulinum. J Virol 2: 537-540.

Inoue, K., lida, H., 1970. Conversion of toxigenicity in Clostridium botulinum type C. Jap J Microbiol 14: 87-89.

Janse, B.J.H., Gaskell, J., Akhtar, M., Cullen, D., 1998. Expression of Phanerochaete chrysosporium genes encoding lignin peroxidases, manganese peroxidases, and glyoxal oxidase in wood. Appl Environ Microbiol 64: 3536-3538.

Jansen, B.C., 1971. The toxic antigenetic factors produced by Clostridium botulinum types C and D. Onderstepoort J Vet Res 38: 93-98.

Joerger, R.D., Truby, T.M., Hendrickson, E.R., Young, R.M., Ebersole, R.C., 1995. Analyte detection with DNA-Labeled antibodies and polymerase chain reaction. Clin Chem 41: 1371-1377.

Jung, A., Ottosson, J., 2001. Infantile botulism caused by honey. Ugeskr Laeger 163: 169.

Kaufman, G.E., Blackstone, G.M., Vickery, M.C., Bej, A.K., Bowers, J., Bowen, M.D., Meyer, R.F., DePaola, A., 2004. Real-time PCR quantification of Vibrio parahaemolyticus in oysters using an alternative matrix. J Food Prot 67: 2424-2429.

Kautter, D.A., Harmon, S.M., Lynt, R.K.Jr, and Lilly, T.Jr., 1966. Antagonistic effect on Clostridium botulinum type $\mathrm{E}$ by organisms resembling it. Appl Microbiol 14: 616-622.

Kautter, D.A., Lilly, T., Solomon, H.M., Lynt, R.K., 1982. Clostridium botulinum spores in infant foods: a survey. J. Food Prot 45: 1028-1029.

Kautter, D.A., Solomon, H.M., Lake, D.E., Bernard, D.T., Mills, D.C., 1992. Clostridium botulinum and its toxins. In: Vanderzant, C., Splittstoesser, 
D.F. (eds.) Compendium of methods for the microbiological examination of foods, $3^{\text {rd }}$ ed, American Public Health Association, Washington, D.C. pp. 605-621.

Keet, C.A., Fox, C.K., Margeta, M., Marco, E., Shane, A.L., Dearmond, S.J., Strober, J.B., Miller, S.P., 2005. Infant botulism, type F, presenting at 54 hours of life. Pediatr Neurol 32: 193-196.

Kihm, D.J., Hutton, M.T., Hanlin, J.H., Johnson, E.A., 1990. Influence of transition metals added during sporulation on heat resistance of Clostridium botulinum 113B spores. Appl Environ Microbiol 56: 681-685.

Kim, J., Foegeding, P.M., 1993. Principles of control. In: Hauschild, A.H.W., Dodds, K.L. (eds.) Clostridium botulinum: ecology and control in foods. New York: Marcel Dekker, pp. 121-176.

Kimura, B., Kawasaki, S., Nakano, H., Fujii, T., 2001. Rapid, quantitative PCR monitoring of growth of Clostridium botulinum type $\mathrm{E}$ in modifiedatmosphere-packaged fish. Appl Environ Microbiol 67: 206-216.

Kimura, K., Fujii, N., Tsuzuki, K., Murakami, T., Indoh, T., Yokosawa, N., Takeshi, K., Syuto, B., Oguma, K., 1990. The complete nucleotide sequence of the gene coding for botulinum type C1 toxin in the C-ST phage genome. Biochem Biophys Res Commun 171: 1304-13011.

Klewitz, T.M., 2005. Entwicklung eines quantitativen Lateral-FlowImmunoassays zum Nachweis von Analyten in geringsten Konzentrationen. Diss. Rer. Nat. Hannover (also in http://edok01.tib.unihannover.de/edoks/e01dh05/47972993X.pdf (accessed on 07.04.2006)

Kothare, S.V., Kassner, E.G., 1995. Infant botulism: a rare cause of colonic ileus. Pediatr Radiol 25: 24-26.

Kourilov, V., Steinitz, M., 2002. Magnetic-bead enzyme-linked immunosorbent assay verifies adsorption of ligand and epitope accessibility. Anal Biochem 311: 166-170.

Kozaki, S., Kamata, Y., Nagai, Y., Ogasawara, J., Sakaguchi, G., 1986. The use of monoclonal antibodies to analyze the structure of Clostridium botulinum type E derivate toxin. Infect Immun 52: 786-791.

Kriek, N.P.J., Odendaal, M.W., 1994. Botulism. In: Coetzer, J.A.W., Thomson, G.R., Tustin, R.C. (eds.) Infectious diseases of livestock. Kapstadt, Oxford University Press, Vol. 2, pp. 1354-1371. 
Kumar, P., Colston, J.T., Chambers, J.P., Rael, E.D., Valdes, J.J., 1994.

Detection of botulinum toxin using an evanescent wave immunosensor. Biosens Bioelectron 9: 57-63.

Kwan, P.L., Lee, J.S., 1974. Compound inhibitory to Clostridium botulinum type

E produced by a Moraxella species. Appl Microbiol 27: 329-332.

Lamanna, C., 1959. The most poisonous poison. Science 130: 763-772.

Lau, A.H.S., Hawirko, R., Chow, C., 1974. Purification and properties of boticin

P produced by Clostridium botulinum. Can J Microbiol 20: 385-390.

Lawson, P.A., Llop-Perez, P., Hutson, R.A., Hippe, H., Collins, M.D., 1993.

Towards a phylogeny of the clostridia based on 16S rRNA sequences.

FEMS Microbiol Lett 113: 87-92.

Lee, S.Y., Bollinger, J., Bezdicek, D., Ogram, A., 1996. Estimation of the abundance of an uncultured soil bacterial strain by a competitive quantitative PCR method. Appl Environ Microbiol 62: 3787-3793.

Lee, W.H., Riemann, H., 1970. The genetic relatedness of proteolytic Clostridium botulinum strains. J Gen Microbiol 64: 85-90.

Li, L., Singh, B.R., 1998. Isolation of synaptotagmin as a receptor for types A and $E$ botulinum neurotoxin and analysis of their comparative binding using a new microtiter plate assay. J Nat Toxins 7: 215-226.

Ligler, F.S., Taitt, C.R., Shriver-Lake, L.C., Sapsford, K.E., Shubin, Y., Golden, J.P., 2003. Array biosensor for detection of toxins. Anal Bioanal Chem 377: 469-477.

Lilly, T., Rhodehamel, E.J., Kautter, D.A., Solomon, H.M., 1991. Clostridium botulinum spores in corn syrup and other syrups. J Food Protect 54: 585587.

Lindström, M, Keto, R., Markkula, A., Nevas, M., Hielm, S., Korkeala, H., 2001. Multiplex PCR assay for detection and identification of Clostridium botulinum types A, B, E, and F in food and faecal material. Appl Environm Microbiol 67: 5694-5699.

Liu, W., Montana, V., Chapman, E.R., Mohideen, U., Parpura, V., 2003. Botulinum toxin type B micromechanosensor. Proc Natl Acad Sci USA 100: 13621-13625. 
Lund, B., Peck, M., 2000. Clostridium botulinum. In: Lund, B.M., Baird-Parker, T.C., Gould, G.W. (eds.) The microbiological safety and quality of food, Vol. 2, pp. 1057-1109.

Mäde, D., Trümper, K., Stark, R., 2000. Nachweis von Clostridium botulinum in Honig durch Polymerase-Kettenreaktion. Arch Lebensmittelhyg 51: 68-70. Maksymowych, A.B., Simpson, L.L., 1998. Binding and transcytosis of botulinum neurotoxin by polarized human colon carcinoma cells. J Biol Chem 273: 21950-21957.

Mantynen, V., Niemela, S., Kaijalainen, S., Pirhonen, T., Lindström, K., 1997. MPN-PCR-quantification method for staphylococcal enterotoxin c1 gene from fresh cheese. Int J Food Microbiol 36: 135-143.

Martin, B., Jofre, A., Garriga, M., Hugas, M., Aymerich, T., 2004. Quantification of Listeria monocytogenes in fermented sausages by MPN-PCR method. Lett Appl Microbiol 39: 290-295.

Maselli, R.A., Ellis, W., Mandler, R.N., Sheikh, F., Senton, G., Knox, S., SalariNamin, H., Agius, M., Wollmann, R.L., Richman, D.P., 1997. Cluster of wound botulism in California: clinical, electrophysiologic, and pathologic study. Muscle Nerve 20: 1284-1295.

McCroskey, L.M., Hatheway, C., Woodruff, B., Greenberg, J., Jurgenson, P., 1991. Type F botulism due to neurotoxigenic Clostridium baratii from an unknown source in an adult. J Clinic Microbiol 29: 2618-2620.

McCroskey, L.M., Hatheway, C.L., Fenicia, L., Pasolini, B., Aureli, P., 1986 Characterization of an organism that produces type $E$ botulinal toxin but which resembles Clostridium butyricum from the feces of an infant with type E botulism. J Clin Microbiol 23: 201-202.

McGrath, S., Dooley, J.S., Haylock, R.W., 2000. Quantification of Clostridium botulinum toxin gene expression by competitive reverse transcriptionPCR. Appl Environ Microbiol 66: 1423-1428.

Mercanoglu, B., Griffiths, M.W., 2005. Combination of immunomagnetic separation with real-time PCR for rapid detection of Salmonella in milk, ground beef, and alfalfa sprouts. J Food Prot 68: 557-561.

Merivirta, L.O., Lindström, M., Bjorkroth, K.J., Korkeala, H.J., 2006. The prevalence of Clostridium botulinum in European river lamprey (Lampetra fluviatilis) in Finland. Int J Food Microbiol 109: 234-237. 
Meyer, K.F., 1928. Botulismus. In: Kolle, W., Kraus, R., Uhlenhuth, P. (Hrsg.) Handbuch der pathogenen Mikroorganismen. 3. Aufl. Bd. IV, 2. Fischer und Urban\&Schwarzenberg, Jena, pp.1269-1364.

Meyer, K.F., 1964. Reports from the scientific board. Calif Med 100: 48-49. Midura, T.F., 1996. Update: infant botulism. Clin Microbiol Rev 9: 119-125.

Midura, T.F., Arnon, S.S., 1976. Infant botulism: identification of Clostridium botulinum and its toxins in faeces. Lancet 2: 934-936.

Midura, T.F., Nygaard, G.S., Wood, R.M., Bodily, H.L., 1972. Clostridium botulinum type F: isolation from venison jerky. Appl Microbiol 24: 165-167.

Midura, T.F., Snowden, S., Wood, R.M., Arnon, S.S., 1979. Isolation of Clostridium botulinum from honey. J Clin Microbiol 9: 282-283.

Miller, M.B., Bassler, B.L., 2001. Quorum sensing in bacteria. Annu Rev Microbiol 55: 165-199.

Mills, D.C., Midura, T., Arnon, S., 1985. Improved selective medium for the isolation of lipase positive Clostridium botulinum from feces of human infants. J Clin Microbiol 21: 947-950.

Minic, Z., Laporte, J., Couchy, I., Popoff, M.R., Jeunemaître, B.S., Brown, S., 1999. Probing the action of Clostridium toxins $B$ and exoenzyme $\mathrm{C}_{3}$ for detection of Rho-like motifs of alfalfa proteins. Plant Physiol Biochem 37: 775-787.

Miwa, N., Nishio, T., Arita, Y., Kawamori, F., Masuda, T., Akiyama, M., 2003. Evaluation of MPN method combined with PCR procedure for detection and enumeration of Vibrio parahaemolyticus in seafood. J Food Hyg Soc Japan 44: 289-293.

Moeller, R.B. Jr., David, U.C., 2003. Clostridium botulinum type C in cattle: Determination of the median lethal dose for cattle and the detection of the toxin in milk by standard techniques. In: Californian Dairy Research Foundation, Food Safety, and Quality. http://www.cdrf.org/content.asp?contentID=75 (accessed on 24.11.2003). Monetto, M.A., Francavilla, A., Rondini, A., Manca, L., Siravegna, M., Fernandez, R., 1999. A study of botulinum spores in honey. Anaerobe 5: 185-186.

Monsalve, C.J., Alcolea, N.S.A., 1999. Infantile botulism. An Esp Pediatr 51: 572-573. (In Spanish) 
Montecucco, C., Schiavo, G., 1994. Mechanism of action of tetanus and botulinum neurotoxins. Mol Microbiol 13: 1-8.

Munchau, A., Bhatia, K.P., 2000. Uses of botulinum toxin injection in medicine today. BMJ 320: 161-165.

Nakano, H., Sakaguchi, G., 1991. An unusually heavy contamination of honey products by Clostridium botulinum type $\mathrm{F}$ and Bacillus alvei. FEMS Microbiol Lett 63: 171-177.

Nakano, H., Okabe, T., Hashimoto, H., Sakaguchi, G., 1990. Incidence of Clostridium botulinum in honey of various origins. Jpn J Med Sci Biol 43: 183-195.

Nevas, M., Hielm, S., Lindström, M., Horn, H., Koivulehto, K., Korkeala, H., 2002. High prevalence of Clostridium botulinum types $A$ and $B$ in honey samples detected by polymerase chain reaction. Int J Food Microbiol 72: 45-52.

Nevas, M., Lindström, M., Hautamaki, K., Puoskari, S., Korkeala, H., $2005 a$. Prevalence and diversity of Clostridium botulinum types A, B, E and F in honey produced in the Nordic countries. Int J Food Microbiol 105: 145151.

Nevas, M., Lindström, M., Virtanen, A., Hielm, S., Kuusi, M., Arnon, S.S, Vuori, E., Korkeala, H., 2005b. Infant botulism acquired from household dust presenting as sudden infant death syndrome. J Clin Microbiol 43: 511-513. Nogva, H.K., Lillehaug, D., 1999. Detection and quantification of Salmonella in pure cultures using 5 '-nuclease polymerase chain reaction. Int J Food Microbiol 51: 191-196.

Notermans, S., Dufrenne, J., Kozaki, S., 1982a. The relation between toxicity and toxin-related-antigen contents of Clostridium botulinum types $C$ and $D$ cultures as determined by mouse bioassay and ELISA. Jpn J Med Sci Biol 35: 203-211.

Notermans, S., Hagenaars, A.M., Kozaki, S., 1982b. The enzyme-linked immunosorbent assay for the detection and determination of Clostridium botulinum toxins A, B, and E. Methods Enzymol 84: 223-238.

Ogert, R.A., Brown, J.E., Singh, B.R., Shriver-Lake, L.C., Ligler, F.S., 1992. Detection of Clostridium botulinum toxin A using a fiber optic-based biosensor. Anal Biochem 205: 306-312. 
Oguma, K., Murayama, S., Syuto, B., lida, H., Kubo, S., 1984. Analysis of antigenicity of Clostridium botulinum type $C_{1}$ and $D$ toxins by polyclonal and monoclonal antibodies. Infect Immun 43: 584-588.

Oguma, K., Yamaguchi, T., Sudou, K., Yukosawa, N., Fujikawa, Y., 1986. Biochemical classification of Clostridium botulinum type $C$ and $D$ strains and their nontoxigenic derivates. Appl Environ Microbiol 51: 256-260.

Oguma, K., Yokota, K., Hayashi, S., Takeshi, K., Kumagai, M., Itoh, N., Tachi, N., Chiba, S., 1990. Infant botulism due to Clostridium botulinum type C toxin. Lancet 336: 1449-1450.

Ohishi, I., Odagiri, Y., 1984. Histopathological effect of $\mathrm{C}_{2}$ botulinum toxin on mouse intestines. Infect Immun 43: 54-58.

Ohtani, K., Hayashi, H., Shimizu, T., 2002. The luxS gene is involved in cell-cell signalling for toxin production in Clostridium perfringens. Mol Microbiol 44: 171-179.

Paisley, J.W., Lauer, B.A., Arnon, S.S., 1995. A second case of infant botulism type F caused by Clostridium baratii. Pediatr Infect Dis J 14: 912-914.

Passaro, D.J., Werner, S.B, McGee, J., Mac Kenzie, W.R., Vugia, D.J., 1998. Wound botulism associated with black tar heroin among injection drug users. J Am Med Assoc 279: 859-963.

Peck, M.W., Fairbairn, D.A., Lund, B.M., 1992. The effect of recovery medium on the estimated heat-inactivation of spores of non-proteolytic Clostridium botulinum. Letters in Applied Microbiology 15: 146-151.

Peeler, J.T., Houghtby, G.A., Rainosek, A.P., 1992. The most probable number technique. In Vanderzant, C., Splittstoesser, D.F. (eds.) Compendium of methods for the microbiological examination of foods, $3^{\text {rd }}$ ed. American Public Health Association, Washington, D.C. pp. 105-120.

Perkins, W.E., 1965. Production of clostridial spores. J Appl Bact 28: 1-16. Pickett, J., Berg, B., Chaplin, E., Brunstetter-Shafer, M., 1976. Syndrome of botulism in infancy: clinical and electrophysiological. New Engl J Med 295: 770-772.

Poli, M.A., Rivera, V.R., Neal, D., 2002. Development of sensitive colorimetric capture ELISAs for Clostridium botulinum neurotoxin serotypes $\mathrm{E}$ and $\mathrm{F}$. Toxicon 40: 797-802. 
Potter, M.D., Meng, J., Kimsey, P., 1993. An ELISA for detection of botulinal toxin types A, B, and E in inoculated food samples. J Food Prot 56: 856861.

Poulet, S., Hauser, D., Quanz, M., Niemann, H., Popoff, M., 1992. Sequences of the botulinal neurotoxin $\mathrm{E}$ derived from Clostridium botulinum type $\mathrm{E}$ (strain Beluga) and Clostridium butyricum (strains ATCC 43181 and ATTC 43755). Biochem Biophys Res Commun 183: 107-113.

Prevot, A.R, Terrasse, J., Daumail, J., Cavaroc, M., Riol, J., Sillioc, R., 1955. [Existence of type C botulism in man in France.] Bull Acad Natl Med 139: 355-358. (In French)

Rall, V.L.M., Bombo, A.J., Lopes, T.F., Carvalho, L.R., Silva, M.G., 2003. Honey consumption in the state of São Paulo: a risk to human health? Anaerobe 9: 299-303.

Reiner, E., Bayer, F.L., 1978. Botulism: a pyrolysis-gas-liquid chromatographic study. J Chromatogr Sci 16: 623-629.

Rieke, K., 1981. Differenzierung von Clostridia mit Hilfe der gaschromatographischen Analyse metabolisch gebildeter Fettsäuren. Diss. Sc. Agr. Göttingen.

Robert Koch Institute 2000. Falldefinitionen des Robert Koch-Instituts zur Übermittlung von Erkrankungs- oder Todesfällen und Nachweisen von Krankheitserregern.

Roberts, T.A., 1965. Sporulation of $C$. botulinum type $E$ in defferent culture media. J Appl Bact 28: 142-146.

Robinson, R.F., Nahata, M.C., 2003. Management of botulism. Ann Pharmacother 37: 127-131.

Rocke, T.E., 1993. Clostridium botulinum. In: Gyles, C.L., Thoen, C.O. (eds.) Pathogenesis of bacterial infections in animals, $2^{\text {nd }}$ ed. Ames, IA, lowa State University Press, pp. 86-96.

Rocke, T.E., Smith, S.R., Nashold, S.W., 1998. Preliminary evaluation of a simple in vitro test for the diagnosis of type $\mathrm{C}$ botulism in wild birds. J Wildl Dis 34: 744-751.

Roman, M.G., Humber, J.Y., Hall, P.A., Reddy, N.K., Solomon, H.M., Triscott, M.X., Beard, G.A., Bottoms, J.D., Cheng, T., Doellgast, G.J., 1994. 
Amplified immunoassay ELISA-ELCA for measuring Clostridium botulinum type E neurotoxin in fish fillets. J Food Protect 57: 985-990.

Rossetto, O., Deloye, F., Poulain, B., Pellizzari, R., Schiavo, G., Montecucco, C., 1995. The metallo-proteinase activity of tetanus and botulism neurotoxins. J Physiol 89: 43-50.

Saeed, E.M.A., 2005. Studies on isolation and identification of Clostridium botulinum investigating field samples specially from equine grass sickness cases. Diss. Sc. Agr. Göttingen, (http://webdoc.sub.gwdg.de/diss/2005/saeed/saeed.pdf, accessed on $30^{\text {th }}$ July, 2005).

Sakaguchi, G., 1988. Honey and botulism. Jpn J Food Microbiol 5: 3-9.

Sandler, R.J., Rocke, T.E., Yuill, T.M., 1998. The inhibition of Closridium botulinum type $\mathrm{C}$ by other bacteria in wetland sediments. J Wildl Dis 34 : 830-833.

Sandler, R.J., Rocke, T.E., Samuel, M.D., Yuill, T.M., 1993. Seasonal prevalence of Clostridium botulinum type $C$ in sediments of a northern California wetland. J Wild Dis 29: 533-539.

Sano, T., Smith, C.L., Cantor, C.R., 1992. Immuno-PCR: very sensitive antigen detection by means of specific antibody-DNA conjugates. Science 258 : 120-122.

Savill, M.G., Hudson, J.A., Ball, A., Klena, J.D., Scholes, P., Whyte, R.J., McCormick, R.E., Jankovic, D., 2001. Enumeration of Campylobacter in New Zealand recreational and drinking waters. J Appl Microbiol 91: 38-46.

Schantz, E., Kautter, D.A., 1978. Standardized assay for Clostridium botulinum toxins. J Assoc Off Anal Chem 61: 96-99.

Schantz, E.J and Johnson, E.A., 1992. Properties and use of botulinum toxin and other microbial neurotoxins in medicine. Microbiol Rev 56: 80-99.

Schiavo, G., Benfenati, F., Poulain, B., Rossetto, O., Polverino de laureto, P., DasGupta, B.R., Montecucco, C., 1992. Tetanus and botulinum-B neurotoxins block neurotransmitter release by proteolytic cleavage of synaptobrevin. Nature 359: 832-835.

Schmidt, C.F., Lechowich, R.V., Folinazzo, J.F., 1961. Growth and toxin production by type E Clostridium botulinum below $40^{\circ} \mathrm{F}$. J Food Sci 26 : 626-630. 
Schmidt, J.J., Bostian, K.A., 1995. Proteolysis of synthetic peptides by type A botulinum neurotoxin. J Protein Chem 14: 703-708.

Schmidt, R.D., Schmidt, T.W., 1992. Infant botulism: a case series and review of the literature. J Emerg Med 10: 713-718.

Schocken-Iturrino, R.P., Carneiro, M.C., Kato, E., Sorbara, J.O., Rossi, O.D., Gerbasi, L.E., 1999. Study of the presence of the spores of $C$. botulinum in honey in Brazil. FEMS Immunol Med Microbiol 24: 379-382.

Scott, V.N., Duncan, C., 1978. Cryptic plasmids in Clostridium botulinum and C. botulinum-like organisms. FEMS Microbiol Lett 4: 55-58.

Segner, W.P., Schmidt, C.F., Boltz, J.K., 1971. Enrichment, isolation and cultural characteristics of marine strains of Clostridium botulinum type C. Appl Microbiol 22: 1017-1024.

Shapiro, R.L., Hatheway, C., Swerdlow, D.L., 1998. Botulism in the United States: a clinical and epidemiologic review. Ann Intern Med 129: 221-228. Sharma, S.K., Eblen, B.S., Bull, R.L., Burr, D.H., Whiting, R.C., 2005. Evaluation of lateral-flow Clostridium botulinum neurotoxin detection kits for food analysis. Appl Environ Microbiol 71: 3935-3941.

Shone, C., Wilton-Smith, P., Appleton, N., Hambleton, P., Modi, N., Gatley, S., Melling, J., 1985. Monoclonal antibody-based immunoassay for type A Clostridium botulinum toxin is comparable to the mouse bioassay. Appl Environ Microbiol 50: 63-67.

Simpson, L.L., 1989. Peripheral actions of the botulinum toxins. In: Simpson, L.L. (eds.) Botulinum neurotoxin and tetanus toxin. Academic Press, Orlando. pp. 153-178.

Simpson, L.L., 1999. Botulinum toxin: potent poison, potent medicine. Hospital Practice. http://www.hosppract.com/issues/1999/04/simpson.htm (accessed on 24.11.2005).

Simpson, L.L., Maksymowych, A.B., Kiyatkin, N., 1999. Botulinum toxin as carrier for oral vaccines. Cell Mol Life Sci 56: 47-61.

Singer J.M., Plotz C.M., 1956. The latex fixation test. I. Application to the serologic diagnosis of rheumatoid arthritis. Am J Med 21: 888-892.

Singh, A.K., Harrison, S.H., Schoeniger, J.S., 2000. Gangliosides as receptors for biological toxins: development of sensitive fluoroimmunoassays using ganglioside-bearing liposomes. Anal Chem 72: 6019-6024. 
Smelt, J.P.P.M., Raatjes, G., Crowther, J., Verrips, C., 1982. Growth and toxin formation by Clostridium botulinum at low pH values. J Appl Bacteriol 52: 75-82.

Smith, J.L., Fratamico, P.M., Novak, J.S., 2004. Quorum sensing: a primer for food microbiologists. J Food Prot 67: 1053-1070.

Smith, L.D., Sugiyama, H., 1988. Botulism. The organism, its toxins, the disease. $2^{\text {nd }}$ ed. Charles C. Thomas, Springfield.

Solomon, H.M., Lilly, T.Jr., 2001. Clostridium botulinum. In: FDA. Bacteriological analytical manual online, Chapter 17, pp. 1-10.

http://www.cfsan.fda.gov/ ebam/bam-17.html (accessed on 24.11.2005).

Song, Y., Liu, C., Finegold, S.M., 2004. Real-time PCR quantitation of Clostridia in feces of autistic children. Appl Environ Microbiol 70: 6459-6465.

Sonnabend, O.A.R., Sonnabend, W., Krech, U., Molz, G., Sigrist, T., 1985. Continuous microbiological and pathological study of 70 sudden and unexpected infant deaths: toxigenic intestinal Clostridium botulinum infection in 9 cases of sudden infant death syndrome. Lancet 1: 237-241.

Sperber, W.H., 1982. Requirements of Clostridium botulinum for growth and toxin production. Food Technol 36: 89-94.

Spika, J.S., Shaffer, N., Hargrett-Bean, N., Collin, S., MacDonald, K.L., Blake, P.A., 1989. Risk factors for infant botulism in the United States. Am J Dis Child 143: 828-832. (Erratum in: Am J Dis Child 1990, 144: 60).

Strom, M.S., Eklund, M.W., Poysky, F.T., 1984. Plasmids in Clostridium botulinum and related Clostridium species. Appl Environ Microbiol 48: 956963.

Suen, J.C., Hatheway, C.L., Steigerwalt, A.G., Brenner, D.J., 1988. Clostridium argentinense sp. Nov.: a genetically homogeneous group composed of all strains of Clostridium botulinum toxin type $G$ and some nontoxigenic strains previously identified as Clostridium subterminale or Clostridium hastiforme. Int J Syst Bacteriol 38: 375-381.

Sugiyama, H., 1988. Botulism. Charles C. Thomas, pp. 23-24.

Sugiyama, H., Mills, D.C., 1978. Intraintestinal toxin in infant mice challenged intragastrically with Clostridium botulinum spores. Infect Immun 21: 59-63.

Sugiyama, H., Mills, D.C., Kuo, L-J.C., 1978. Number of Clostridium botulinum spores in honey. J Food Protect 41: 848-850. 
Swerczek, T.W., 1980. Toxicoinfectious botulism in foals and adult horses. J Am Vet Med Assoc 176: 217-220.

Szabo, E.A., Pemberton, J.M., Desmarchelier, P.M., 1993. Detection of the genes encoding botulinum neurotoxin types $A$ to $E$ by the polymerase chain reaction. Appl Environ Microbiol 59: 3011-3020.

Szabo, E.A., Pemberton, J.M., Gibson, A.M., Eyles, M.J., Desmarchelier, P.M., 1994a. Polymerase chain reaction for detection of Clostridium botulinum types A, B and E in food, soil and infant faeces. J Appl Bacteriol 76: 539545.

Szabo, E.A., Pemberton, J.M., Gibson, A.M., Thomas, R.J., Pascoe, R.R., and Desmarchelier, P.M., 1994b. Application of PCR to a clinical and environmental investigation of a case of equine botulism. J Clin Microbiol 32: 1986-1991.

Szilagyi, M., Rivera, V.R., Neal, D., Merrill, G.A., and Poli, M.A., 2000.

Development of sensitive colorimetric capture ELISAs for Clostridium botulinum neurotoxin serotypes A and B. Toxicon 38: 381-389.

Takeshi, K., Fujinaga, Y., Inoue, K., Nakajima, H., Oguma, K., Ueno, T., Sunagawa, H., and Ohyama, T., 1996. Simple method for detection of Clostridium botulinum type A to $\mathrm{F}$ neurotoxin genes by ploymerase chain reaction. Microbiol Immunol 40: 5-11.

Thilo, E., Townsend, S., 1993. Infant botulism at 1 week of age: report of two cases. Pediatrics 92: 151-153.

Thomas, R.J., 1991. Detection of Clostridium botulinum types C and D toxin by ELISA. Aust Vet J 68: 111-113.

Thompson, D.E., Brehm, J., Oultram, J., Swinfield, T., Shone, C., Atkinson, T., Melling, J., Minton, P., 1990. The complete amino acid sequence of the Clostridium botulinum type A neurotoxin, deduced by nucleotide sequence analysis of the encoding gene. Eur J Biochem 189: 73-81.

Thompson, J.A., Filloux, F.M., Van Orman, C.B., Swoboda, K., Peterson, P., Firth, S.D., Bale, J.F.Jr., 2005. Infant botulism in the age of botulism immune globulin. Neurology 64: 2029-2032.

Tollofsrud, P.A., Kvittingen, E.A., Granum, P.E., Vollo, A., 1998. Botulism in newborn infants. Tidsskr Nor Laegeforen 118: 4355-4356. 
Trueman, K.F., Bock, R.E., Thomas, R.J., Taylor, J.D., Green, P.A., Roeger, H.M., Ketterer, P.J., 1992. Suspected botulism in three intensively managed Australian cattle herds. Vet Rec 130: 398-400.

Tsuji, K., Perkins, W.E., 1962. Sporulation of Clostridium botulinum. I. Selection of an aparticulate sporulation medium. J Bacteriol 84: 81-85.

Turner, H.D., Brett, E.M., Gilbert, R.J., Ghosh, A.C., Liebeschuetz, H.J., 1978. Infant botulism in England. Lancet 1: 1277-1278.

Urquhart, G.E.D., Grist, N.R., 1976. Botulism and sudden infant death. Lancet ii: $1411-1412$.

Weber, J.T., Goodpasture, H.C., Alexander, H., Werner, S.B., Hatheway, C.L., Tauxe, R.V., 1993. Wound botulism in a patient with a tooth abscess: case report and review. Clin Infect Dis 16: 635-639.

Werner, S.B., Passaro, D., McGee, J., Schechter, R., Vugia, D.J., 2000. Wound botulism in California, 1951-1998: recent epidemic in heroin injectors. Clin Infect Dis 31: 1018-1024.

Whelan, S.M., Elmore, M.J., Bodsworth, N.J., Atkinson, T., Minton, N.P., 1992a. The complete amino acid sequence of the Clostridium botulinum type-E neurotoxin, derived by nucleotide-sequence analysis of the encoding gene. Eur J Biochem 204: 657-667.

Whelan, S.M., Elmore, M.J., Bodsworth, N.J., Brehm, J.K., Atkinson, T., Minton, N.P., 1992b. Molecular cloning of the Clostridium botulinum structural gene encoding the type B neurotoxin ad determination of its entire nucleotide sequence. Appl Environ Microbiol 58: 2345-2354.

Wictome, M., Newton, K., Jameson, K., Hallis, B., Dunnigan, P., Mackay, E., Clarke, S., Taylor, R., Gaze, J., Foster, K., Shone, C., 1999. Development of an in vitro bioassay for Clostridium botulinum type $B$ neurotoxin in foods that is more sensitive than the mouse bioassay. Appl Environ Microbiol 65: 3787-3792.

Willems, A., East, A.K., Lawson, P.A., Collins, M.D., 1993. Sequence of the gene coding for the neurotoxin of Clostridium botulinum type $A$ associated with infant botulism: comparison with other clostridial neurotoxins. Res Microbiol 144: 547-556. 
Williamson, J.L., Rocke, T.E., Aiken, J.M., 1999. In situ detection of the Clostridium botulinum type $\mathrm{C}_{1}$ toxin gene in wetland sediments with a nested PCR assay. Appl Environ Microbiol 65: 3240-3243.

Willinger, M., James, L.S., Catz, C., 1991. Defining the sudden infant death syndrome (SIDS): deliberations of an expert panel convened by the National Institute of Child Health and Human Development. Pediatr Pathol 11: 677-684.

Withers, H.L., Nordstrom, K., 1998. Quorum-sensing acts at initiation of chromosomal replication in Escherichia coli. Proc Natl Acad Sci USA 95: 15694-15699.

Woodruff, B.A., Griffin, P., McCroskey, L., Smart, J., Wainwright, R., Bryant, R., Hutwagner, L., Hatheway, C.L., 1992. Clinical and laboratory comparison of botulism from toxin types A, B, and E in the United States, 1975-1988. J Infect Dis 166: 1281-1286.

Wu, H.C., Huang, Y.L., Lai, S.C., Huang, Y.Y., Shaio, M.F., 2001. Detection of Clostridium botulinum neurotoxin type A using immuno-PCR. Lett Appl Microbiol 32: 321-325.

Yang, K.H., Sugiyama, H., 1975. Purification and properties of Clostridium botulinum type $\mathrm{F}$ toxin. Appl Microbiol 29: 598-603.

Yoon, S.Y., Chung, G.T., Kang, D.H., Ryu, C., Yoo, C.K., Seong, W.K., 2005. Application of real-time PCR for quantitative detection of Clostridium botulinum type A toxin gene in food. Microbiol Immunol 49: 505-511.

Zhao, L., Montville, T.J., Schaffner, D.W., 2006. Evidence for quorum sensing in Clostridium botulinum 56A. Lett Appl Microbiol 42: 54-58. 


\section{APPENDIX}

All chemicals are from MERCK (Darmstadt, Germany), otherwise will be stated

\subsection{Media}

Duncan-Strong Medium (M45, FDA) modified

\begin{tabular}{lc} 
& $\mathrm{g} \mathrm{L}^{-1}$ \\
\hline Yeast extract & 4.0 \\
Proteose peptone & 15.0 \\
Soluble starch & 4.0 \\
Sodium thioglycolate & $(1.0)^{\star}$ \\
$\mathrm{Na}_{2} \mathrm{HPO}_{4} 7 \mathrm{H}_{2} \mathrm{O}$ & 10.0 \\
Distilled water & ad $1000 \mathrm{ml}$ \\
\hline
\end{tabular}

$\mathrm{pH} 7.5 \pm 0.2$ at $25^{\circ} \mathrm{C}$

Autoclave at $121^{\circ} \mathrm{C}$ for $15 \mathrm{~min}$.

*, amount of Sodium thioglycolate used only in case it was added to the medium.

Fastidious Anaerobe Agar with Blood (FAAB)

\begin{tabular}{lc} 
& $\mathrm{g} \mathrm{L}^{-1}$ \\
\hline Casein peptone & 10.0 \\
Meat peptone & 10.0 \\
Yeast extract & 3.0 \\
Dextrose (or D-Glucose monohydrate) & 1.0 \\
Soluble starch & 1.0 \\
Sodium chloride & 5.0
\end{tabular}


Sodium pyruvate

Sodium bicarbonate

L-Cysteine hydrochloride

L-Arginine

Trizma base

Haemin

Vitamin K1

Sodium succinate

Agar

Distilled water
1.0

0.4

0.5

1.0

0.25

0.01

0.001

0.5

14.0

ad $1000 \mathrm{ml}$

$\mathrm{pH} 7.2 \pm 0.2$ at $25^{\circ} \mathrm{C}$

After autoclaving at $121{ }^{\circ} \mathrm{C}$ for $15 \mathrm{~min}, 50 \mathrm{~mL}$ of defibrinated horse blood (OXOID, Wesel) were aseptically added.

Haemin, L-Arginine, trizma base, and sodium bicarbonate were obtained from SIGMA (SIGMA-ALDRICH, Germany).

FAA is an enriched non-selective solid medium used for cultivation and isolation of obligate and facultative anaerobes, especially those that present in low numbers. Hemin and vitamin K1 enrichments enhance the growth of Bacteriodes $s p$. The low level of glucose prevents the production of high levels of acids and alcohols which would inhibit colonial development.

\section{Fastidious Anaerobe Agar with Egg Yolk (FAAE)}

\begin{tabular}{lr} 
& $\mathrm{g} \mathrm{L}^{-1}$ \\
\hline Casein peptone & 10.0 \\
Meat peptone & 10.0 \\
Yeast extract & 3.0 \\
Dextrose (or D-Glucose monohydrate) & 1.0 \\
Soluble starch & 1.0
\end{tabular}


Sodium chloride

Sodium pyruvate

Sodium bicarbonate

L-Cysteine hydrochloride

L-Arginine

Trizma base

Haemin

Vitamin K1

Sodium succinate

Agar

Distilled water

$\mathrm{pH} 7.2 \pm 0.2$ at $25{ }^{\circ} \mathrm{C}$

After autoclaving at $121^{\circ} \mathrm{C}$ for $15 \mathrm{~min}, 50 \mathrm{~mL}$ of egg-yolk emulsion (BECTON DICKINSON, Sparks) were added aseptically.

Haemin, L-Arginine, trizma base, and sodium bicarbonate were obtained from SIGMA-ALDRICH, Germany.

\section{Fastidious Anaerobe Broth (FAB)}

\begin{tabular}{lc} 
& $\mathrm{g} \mathrm{L}^{-1}$ \\
\hline Casein peptone & 10.0 \\
Meat peptone & 10.0 \\
Yeast extract & 3.0 \\
Dextrose (or D-Glucose monohydrate) & 1.0 \\
Soluble starch & 1.0 \\
Sodium chloride & 5.0 \\
Sodium pyruvate & 1.0 \\
Sodium bicarbonate & 0.4 \\
L-Cysteine hydrochloride & 0.5
\end{tabular}


L-Arginine

Trizma base

Haemin

Vitamin K1

Sodium succinate

Agar

Distilled water

$\mathrm{pH} 7.2 \pm 0.2$ at $25^{\circ} \mathrm{C}$

Autoclave at $121^{\circ} \mathrm{C}$ for $15 \mathrm{~min}$.

Haemin, L-Arginine, trizma base, and sodium bicarbonate were obtained from SIGMA (SIGMA-ALDRICH, Germany).

\section{Modified Anellis Broth (MAB)}

\begin{tabular}{lc} 
& $\mathrm{g} \mathrm{L}^{-1}$ \\
\hline Casein peptone & 50.0 \\
Meat peptone & 5.0 \\
$\mathrm{MnSO}_{4} .4 \mathrm{H}_{2} \mathrm{O}$ & 0.082 \\
$\mathrm{CaCl}_{2}$ & 0.055 \\
$\mathrm{~K}_{2} \mathrm{HPO}_{4}$ & 1.25 \\
$\left(\mathrm{NH}_{4}\right)_{2} \mathrm{SO}_{4}$ & 20.0 \\
Distilled water & ad $1000 \mathrm{ml}$ \\
\hline
\end{tabular}

$\mathrm{pH} 7.5 \pm 0.2$ at $25^{\circ} \mathrm{C}$

Autoclave at $115^{\circ} \mathrm{C}$ for $30 \mathrm{~min}$.

After autoclaving, $10 \mathrm{~mL}$ of sterile $7.5 \% \mathrm{NaHCO}_{3}$ solution were added to $1 \mathrm{~L}$ MAB. The $\mathrm{MnSO}_{4}$ was obtained by either autolaving at $121^{\circ} \mathrm{C}$ for $15 \mathrm{~min}$ or by filtration with $0.2 \mu \mathrm{L}$ PES (polyethersulfone) membrane filter (SARTORIUS, Germany). 
Reinforced Clostridial Medium (RCM)

\begin{tabular}{lc} 
& $\mathrm{g} \mathrm{L}^{-1}$ \\
\hline Yeast extract & 3.0 \\
Peptone from meat & 10.0 \\
Meat extract & 10.0 \\
D-Glucose monohydrate & 5.5 \\
Soluble starch & 1.0 \\
Sodium chloride & 5.0 \\
Sodium acetate & 4.93 \\
L-Cysteine HCl & 0.55 \\
Agar & 0.5 \\
Distilled water & ad $1000 \mathrm{~mL}$ \\
\hline
\end{tabular}

$\mathrm{pH} 6.8 \pm 0.2$ at $25^{\circ} \mathrm{C}$

Blood Agar (BA) has the basis of RCM with addition of $15 \mathrm{~g} \mathrm{~L}^{-1}$ agar. After autoclaving at $121^{\circ} \mathrm{C}$ for $15 \mathrm{~min}, 50 \mathrm{~mL}$ of defibrinated horse blood (OXOID, Wesel) were added aseptically.

If hay was added to this medium, $50 \mathrm{~g}$ of dried hay were soaked in $1000 \mathrm{~mL}$ distilled water overnight. This hay-water would be used to prepare RCM-hay (Reinforced Clostridial Medium with hay). 
Segner Medium (SeM) modified

\begin{tabular}{lc} 
& $\mathrm{g} \mathrm{L}^{-1}$ \\
\hline Yeast extract & 10.0 \\
$\left(\mathrm{NH}_{4}\right)_{2} \mathrm{SO}_{4}$ & 10.0 \\
Glucose & 10.0 \\
Egg meat medium (Difco) & 80.0 \\
Distilled water & ad $1000 \mathrm{~mL}$ \\
\hline
\end{tabular}

$\mathrm{pH} 7.0-7.2$

Autoclave at $121^{\circ} \mathrm{C}$ for $15 \mathrm{~min}$.

Sporulation medium (SM)

\begin{tabular}{ll} 
& $\mathrm{g} \mathrm{L}^{-1}$ \\
\hline Nutrient broth (Difco) & 6.0 \\
Yeast extract & 1.0 \\
Meat peptone & 2.0 \\
$\mathrm{MnSO}_{4} . \mathrm{H}_{2} \mathrm{O}$ & 0.0005 \\
Marine broth (Difco) & 0.5 \\
Inosin (5mM) & $1 \mathrm{~mL}$ \\
Distilled water & $\mathrm{ad} 1000 \mathrm{~mL}$ \\
\hline
\end{tabular}

$\mathrm{pH} 7.8 \pm 1$

Autoclave at $121^{\circ} \mathrm{C}$ for $15 \mathrm{~min}$.

If hay was added to this medium, $50 \mathrm{~g}$ of dried hay were soaked in $1000 \mathrm{~mL}$ distilled water overnight. This hay-water would be used to prepare SM-hay (Sporulation Medium with hay). 
Trypticase Peptone Broth (TPB)

\begin{tabular}{lc} 
& $\mathrm{g} \mathrm{L}^{-1}$ \\
\hline Casein peptone & 50.0 \\
Meat peptone & 5.0 \\
Distilled water & $\mathrm{ad} 1000 \mathrm{~mL}$ \\
\hline
\end{tabular}

Autoclave at $121^{\circ} \mathrm{C}$ for $15 \mathrm{~min}$.

10.2 Solutions and buffers

Gelatine phosphate buffer

Solution A

Gelatine $\quad 4 \%$

$\mathrm{Na}_{2} \mathrm{HPO}_{4} .2 \mathrm{H}_{2} \mathrm{O} \quad 50 \mathrm{mM}$

Distilled water $\quad$ ad $1000 \mathrm{~mL}$

Solution B

$\mathrm{NaH}_{2} \mathrm{PO}_{4} . \mathrm{H}_{2} \mathrm{O}$

$50 \mathrm{mM}$

Distilled water

ad $1000 \mathrm{~mL}$

Solution $A$ and $B$ were mixed together and heated at $60^{\circ} \mathrm{C}$ in a water bath to dissolve gelatine. $\mathrm{pH}$ value was adjusted to 6.2 and the buffer was sterilized at $121^{\circ} \mathrm{C}$ for $15 \mathrm{~min}$.

Phosphate buffered saline

\begin{tabular}{lr}
\hline $\mathrm{NaCl}$ & $120 \mathrm{mM}$ \\
$\mathrm{Na}_{2} \mathrm{HPO}_{4} \cdot 2 \mathrm{H}_{2} \mathrm{O}$ & $20 \mathrm{mM}$ \\
$\mathrm{NaH}_{2} \mathrm{PO}_{4} . \mathrm{H}_{2} \mathrm{O}$ & $6 \mathrm{mM}$ \\
\hline
\end{tabular}

$\mathrm{pH} 7.4$ at $25^{\circ} \mathrm{C}$ 
Autoclave at $121{ }^{\circ} \mathrm{C}$ for $15 \mathrm{~min}$.

Salt solution for sporulation (SSS)

\begin{tabular}{lc} 
& $\mathrm{mg} \mathrm{L}^{-1}$ \\
\hline $\mathrm{CaCl}_{2} \cdot 2 \mathrm{H}_{2} \mathrm{O}$ & 2.65 \\
$\mathrm{MgSO}_{4} \cdot 7 \mathrm{H}_{2} \mathrm{O}$ & 8.2 \\
$\mathrm{MnSO}_{4} \cdot \mathrm{H}_{2} \mathrm{O}$ & 8.8 \\
Distilled water & $\mathrm{ad} 1000 \mathrm{~mL}$ \\
\hline
\end{tabular}

\section{$1 \times$ TBE}

Tris borate

$90 \mathrm{mM}$

EDTA

$2 \mathrm{mM}$

$\mathrm{pH} 8.3$

\section{DNA-polyacrylamide gel (6\%)}

Set clean electrophoresis glass plates with sealer. Mix DNA-PAGE buffer and acrylamide solution. Warm the mixture at $37{ }^{\circ} \mathrm{C}$ for $3 \mathrm{~min}$. Evacuate the mixture briefly to remove small bubbles.

1. Add ammonium persulfate (APS) and TEMED into the acrylamide mixture. Immediately, pour the mixture into the glass plates and stick a comb into the gel solution. Avoid bubbles under the comb teeth. Remove the excess gel solution. Allow to stand at least $30 \mathrm{~min}$ after the gel gets solidified at room temperature.

2. Remove the comb from the gel.

3. Set the gel plates on to an electrophoresis chamber. Pour running buffer (1XTBE buffer) into the chamber. 
4. Apply PCR products (10-16 $\mu \mathrm{L})$ that were mixed with PCR staining solution $(2 \mu \mathrm{L})$ and load electricity at constant $100 \mathrm{~V}$ for mini-gels.

5. The running time is $60-80 \mathrm{~min}$.

DNA-PAGE buffer

\begin{tabular}{lc} 
& $\mathrm{mL}$ \\
\hline $50 \%$ glycerol & 9.8 \\
2xTBE buffer & 48.0 \\
Distilled water & 24.0 \\
\hline
\end{tabular}

\section{Gel composition}

DNA-PAGE buffer $(\mathrm{mL})$

$30 \%$ acrylamide-bis $(\mathrm{mL})$

$10 \%$ APS $(\mu \mathrm{L})$

100

TEMED $(\mu \mathrm{L})$

Total volume $(\mathrm{mL})$

10 


\subsection{DNA sequencing analyses}

Table 19a: Sequence identity rate of PCR products of type B samples

\begin{tabular}{|c|c|c|c|c|}
\hline Name & Samples & Ref. No. GenBank & Position & $\begin{array}{l}\text { Identical } \\
\text { rate }\end{array}$ \\
\hline \multirow[t]{4}{*}{ G 28} & B1f & gi|144734|gb|M81186.1|CLOBOTB & $596-689$ & $98 \%$ \\
\hline & B1r & gi|144734|gb|M81186.1|CLOBOTB & $513-610$ & $97 \%$ \\
\hline & B2f & gi|144734|gb|M81186.1|CLOBOTB & $546-694$ & $99 \%$ \\
\hline & $\mathrm{B} 2 \mathrm{r}$ & Bad sequence & & \\
\hline \multirow[t]{2}{*}{ G 30} & B3f & gi|144734|gb|M81186.1|CLOBOTB & $537-694$ & $99 \%$ \\
\hline & $\mathrm{B} 3 \mathrm{r}$ & gi|144734|gb|M81186.1|CLOBOTB & $488-653$ & $100 \%$ \\
\hline \multirow[t]{2}{*}{ G 31} & B4f & gi|144734|gb|M81186.1|CLOBOTB & $535-694$ & $100 \%$ \\
\hline & B4r & gi|144734|gb|M81186.1|CLOBOTB & $490-632$ & $100 \%$ \\
\hline \multirow[t]{2}{*}{ G 33} & B5f & gi|144734|gb|M81186.1|CLOBOTB & 535-694 & $100 \%$ \\
\hline & B5r & gi|144734|gb|M81186.1|CLOBOTB & $513-639$ & $100 \%$ \\
\hline \multirow[t]{2}{*}{ G 35} & B6f & gi|144734|gb|M81186.1|CLOBOTB & 517-694 & $100 \%$ \\
\hline & B6r & gi|144734|gb|M81186.1|CLOBOTB & $513-654$ & $100 \%$ \\
\hline \multirow[t]{4}{*}{ G 36} & $B 7 f$ & gi|144734|gb|M81186.1|CLOBOTB & $526-694$ & $100 \%$ \\
\hline & B7r & gi|144734|gb|M81186.1|CLOBOTB & $490-654$ & $100 \%$ \\
\hline & B8f & Bad sequence & & \\
\hline & B8r & gi|144734|gb|M81186.1|CLOBOTB & $490-622$ & $100 \%$ \\
\hline \multirow[t]{4}{*}{ VR 34} & B9f & gi|144734|gb|M81186.1|CLOBOTB & $538-694$ & $100 \%$ \\
\hline & B9r & gi|144734|gb|M81186.1|CLOBOTB & $490-589$ & $100 \%$ \\
\hline & B10f & gi|144734|gb|M81186.1|CLOBOTB & $535-694$ & $100 \%$ \\
\hline & B10r & gi|144734|gb|M81186.1|CLOBOTB & $513-609$ & $100 \%$ \\
\hline \multirow[t]{4}{*}{ VR 35} & B11f & Bad sequence & & \\
\hline & B11r & Bad sequence & & \\
\hline & B12f & gi|144734|gb|M81186.1|CLOBOTB & 535-694 & $100 \%$ \\
\hline & B12r & gi|144734|gb|M81186.1|CLOBOTB & 513-631 & $97 \%$ \\
\hline \multirow[t]{2}{*}{ VR 37} & B13f & gi|144734|gb|M81186.1|CLOBOTB & $535-694$ & $100 \%$ \\
\hline & B13r & gi|144734|gb|M81186.1|CLOBOTB & $490-592$ & $100 \%$ \\
\hline \multirow[t]{2}{*}{ VR 38} & B14f & gi|144734|gb|M81186.1|CLOBOTB & $537-694$ & $100 \%$ \\
\hline & B14r & gi|144734|gb|M81186.1|CLOBOTB & $513-633$ & $100 \%$ \\
\hline \multirow[t]{4}{*}{ VR 40} & B15f & gi|144734|gb|M81186.1|CLOBOTB & $525-694$ & $100 \%$ \\
\hline & B15r & gi|144734|gb|M81186.1|CLOBOTB & $490-657$ & $100 \%$ \\
\hline & B16f & gil144734|gb|M81186.1|CLOBOTB & 517-694 & $100 \%$ \\
\hline & B16r & gi|144734|gb|M81186.1|CLOBOTB & $513-654$ & $100 \%$ \\
\hline \multirow[t]{2}{*}{ N 13} & $B 17 f$ & Bad sequence & & \\
\hline & B17r & gi|144734|gb|M81186.1|CLOBOTB & $513-561$ & $100 \%$ \\
\hline \multirow[t]{2}{*}{ MO 7} & B18f & gi|144734|gb|M81186.1|CLOBOTB & $535-694$ & $100 \%$ \\
\hline & B18r & gi|144734|gb|M81186.1|CLOBOTB & $490-603$ & $100 \%$ \\
\hline \multirow[t]{4}{*}{ G 25} & B19f & gi|144734|gb|M81186.1|CLOBOTB & 534-695 & $100 \%$ \\
\hline & B19r & gi|144734|gb|M81186.1|CLOBOTB & $490-639$ & $100 \%$ \\
\hline & B20f & gi|144734|gb|M81186.1|CLOBOTB & 534-694 & $100 \%$ \\
\hline & B2Or & Bad sequence & & \\
\hline \multirow[t]{2}{*}{ G 27} & B21f & gil144734|gb|M81186.1|CLOBOTB & $595-692$ & $98 \%$ \\
\hline & B21r & gi|144734|gb|M81186.1|CLOBOTB & $513-621$ & $99 \%$ \\
\hline
\end{tabular}


Table 19b: Sequence identity rate of PCR products of type B samples (cont.)

\begin{tabular}{|c|c|c|c|c|}
\hline Name & Samples & Ref. No. GenBank & Position & $\begin{array}{l}\text { Identical } \\
\text { rate }\end{array}$ \\
\hline & B22f & gi|144734|gb|M81186.1|CLOBOTB & $525-694$ & $100 \%$ \\
\hline & B22r & gi|144734|gb|M81186.1|CLOBOTB & $513-653$ & $99 \%$ \\
\hline \multirow[t]{4}{*}{ NF 14} & B23f & gi|144734|gb|M81186.1|CLOBOTB & $541-694$ & $100 \%$ \\
\hline & B23r & gi|144734|gb|M81186.1|CLOBOTB & $490-653$ & $100 \%$ \\
\hline & $B 24 f$ & gi|144734|gb|M81186.1|CLOBOTB & $535-694$ & $100 \%$ \\
\hline & $B 24 r$ & gi|144734|gb|M81186.1|CLOBOTB & $490-638$ & $100 \%$ \\
\hline \multirow[t]{4}{*}{ NF 16} & B25f & gi|144734|gb|M81186.1|CLOBOTB & $566-694$ & $98 \%$ \\
\hline & B25r & gi|144734|gb|M81186.1|CLOBOTB & $488-654$ & $99 \%$ \\
\hline & B26f & gi|144734|gb|M81186.1|CLOBOTB & $531-694$ & $100 \%$ \\
\hline & B26r & gi|144734|gb|M81186.1|CLOBOTB & $488-654$ & $100 \%$ \\
\hline \multirow[t]{4}{*}{ NF 19} & B27f & gi|144734|gb|M81186.1|CLOBOTB & $531-694$ & $100 \%$ \\
\hline & B27r & gi|144734|gb|M81186.1|CLOBOTB & $513-654$ & $100 \%$ \\
\hline & B28f & gi|144734|gb|M81186.1|CLOBOTB & $526-694$ & $99 \%$ \\
\hline & B28r & gi|144734|gb|M81186.1|CLOBOTB & $513-633$ & $99 \%$ \\
\hline \multirow[t]{4}{*}{ NF 23} & B29f & gi|144734|gb|M81186.1|CLOBOTB & $535-694$ & $100 \%$ \\
\hline & B29r & gi|144734|gb|M81186.1|CLOBOTB & $490-654$ & $99 \%$ \\
\hline & B30f & gi|144734|gb|M81186.1|CLOBOTB & $531-694$ & $100 \%$ \\
\hline & B30r & gi|144734|gb|M81186.1|CLOBOTB & $513-654$ & $99 \%$ \\
\hline \multirow[t]{4}{*}{ NF 25} & B31f & gi|144734|gb|M81186.1|CLOBOTB & $525-694$ & $99 \%$ \\
\hline & B31r & gi|144734|gb|M81186.1|CLOBOTB & $513-646$ & $99 \%$ \\
\hline & B32f & gi|144734|gb|M81186.1|CLOBOTB & $540-694$ & $100 \%$ \\
\hline & B32r & $.1 \mathrm{CLOBOTB}$ & $490-654$ & $99 \%$ \\
\hline
\end{tabular}


Table 20: Sequence identity rate of PCR products of type C samples

\begin{tabular}{|c|c|c|c|c|}
\hline Name & Samples & Ref. No. GenBank & Position & Identical rate \\
\hline \multirow[t]{2}{*}{ NF 14} & C1f & gi|60360958|dbj|AB200364.1] & $156-549$ & $100 \%$ \\
\hline & C1r & gi $|60360958| \mathrm{dbj} \mid \mathrm{AB} 200364.1$ & $98-508$ & $100 \%$ \\
\hline \multirow[t]{2}{*}{ NF 15} & $C 2 f$ & gi|60360958|dbj|AB200364.1| & $139-539$ & $100 \%$ \\
\hline & $\mathrm{C} 2 \mathrm{r}$ & gi $|60360958| \mathrm{dbj}|\mathrm{AB} 200364.1|$ & $111-507$ & $100 \%$ \\
\hline \multirow[t]{2}{*}{ NF 16} & C3f & gi $|60360958| \mathrm{dbj}|\mathrm{AB} 200364.1|$ & $138-544$ & $100 \%$ \\
\hline & $\mathrm{C} 3 \mathrm{r}$ & gi $|60360958| \mathrm{dbj} \mid \mathrm{AB} 200364.1$ & $98-508$ & $100 \%$ \\
\hline \multirow[t]{4}{*}{ NF 18} & $C 4 f$ & gi $60360958|\mathrm{dbj}| \mathrm{AB} 200364.1$ & $139-339$ & $100 \%$ \\
\hline & $\mathrm{C} 4 \mathrm{r}$ & gi $|60360958| \mathrm{dbj} \mid \mathrm{AB} 200364.1$ & $98-507$ & $99 \%$ \\
\hline & C5f & gi $|60360958| \mathrm{dbj} \mid \mathrm{AB} 200364.1$ & $139-539$ & $100 \%$ \\
\hline & C5r & gi $|60360958| \mathrm{dbj} \mid \mathrm{AB} 200364.1$ & $98-508$ & $100 \%$ \\
\hline \multirow[t]{2}{*}{ NF 19} & C6f & gi $60360958|\mathrm{dbj}| \mathrm{AB} 200364.1$ & $139-549$ & $100 \%$ \\
\hline & C6r & gi $60360958|\mathrm{db}| \mid \mathrm{AB} 200364.1$ & $98-508$ & $100 \%$ \\
\hline \multirow[t]{4}{*}{ NF 20} & $C 7 f$ & gi $|60360958| \mathrm{dbj}|\mathrm{AB} 200364.1|$ & $138-549$ & $100 \%$ \\
\hline & C7r & gi $|60360958| \mathrm{dbj}|\mathrm{AB} 200364.1|$ & $101-508$ & $100 \%$ \\
\hline & C8f & gi $|60360958| \mathrm{dbj}|\mathrm{AB} 200364.1|$ & $139-549$ & $100 \%$ \\
\hline & $\mathrm{C} 8 \mathrm{r}$ & gi $|60360958| \mathrm{dbj}|\mathrm{AB} 200364.1|$ & $98-508$ & $100 \%$ \\
\hline \multirow[t]{2}{*}{ NF 21} & C9f & gi $|60360958| \mathrm{dbj}|\mathrm{AB} 200364.1|$ & $139-549$ & $100 \%$ \\
\hline & C9r & gi $|60360958| \mathrm{dbj}|\mathrm{AB} 200364.1|$ & $98-490$ & $100 \%$ \\
\hline \multirow{2}{*}{ NF 22} & C10f & gi $60360958|\mathrm{dbj}| \mathrm{AB} 200364.1$ & $139-539$ & $100 \%$ \\
\hline & C10r & gi|60360958|dbj|AB200364.1] & $98-508$ & $100 \%$ \\
\hline \multirow[t]{2}{*}{ NF 23} & C11f & Bad sequence & & \\
\hline & C11r & gi $|60360958| d b j \mid A B 200364.1$ & $98-441$ & $99 \%$ \\
\hline \multirow{2}{*}{ NF 24} & C12f & gi $60360958|\mathrm{dbj}| \mathrm{AB} 200364.1$ & $139-549$ & $100 \%$ \\
\hline & C12r & gi|60360958|dbj|AB200364.1 & $107-517$ & $100 \%$ \\
\hline \multirow[t]{2}{*}{ NF 25} & C13f & gi $|60360958| \mathrm{dbj}|\mathrm{AB} 200364.1|$ & $139-539$ & $100 \%$ \\
\hline & C13r & gi $|60360958| \mathrm{dbj}|\mathrm{AB} 200364.1|$ & $98-508$ & $100 \%$ \\
\hline \multirow[t]{2}{*}{ NF 26} & C14f & gi $|60360958| \mathrm{dbj}|\mathrm{AB} 200364.1|$ & $139-539$ & $100 \%$ \\
\hline & C14r & gi|60360958|dbj|AB200364.1 & $98-508$ & $100 \%$ \\
\hline \multirow[t]{4}{*}{ NF 27} & C15f & gi $60360958|\mathrm{dbj}| \mathrm{AB} 200364.1$ & $155-549$ & $100 \%$ \\
\hline & C15r & gi $60360958|\mathrm{dbj}| \mathrm{AB} 200364.1$ & $98-474$ & $100 \%$ \\
\hline & C16f & gi $|60360958| \mathrm{dbj} \mid \mathrm{AB} 200364.1$ & $146-540$ & $100 \%$ \\
\hline & C16r & gi $|60360958| \mathrm{dbj} \mid \mathrm{AB} 200364.1$ & $98-493$ & $100 \%$ \\
\hline \multirow[t]{2}{*}{ NF 28} & C17f & gi $|60360958| \mathrm{dbj} \mid \mathrm{AB} 200364.1$ & $139-459$ & $100 \%$ \\
\hline & C17r & gi $|60360958| \mathrm{dbj} \mid \mathrm{AB} 200364.1$ & $98-517$ & $100 \%$ \\
\hline \multirow[t]{2}{*}{ MO 93} & C18f & gi $60360958|\mathrm{dbj}| \mathrm{AB} 200364.1$ & $139-539$ & $100 \%$ \\
\hline & C18r & gi $|60360958| \mathrm{dbj}|\mathrm{AB} 200364.1|$ & $111-517$ & $100 \%$ \\
\hline \multirow[t]{2}{*}{ MO 94} & C19f & Not identical & & \\
\hline & C19r & Not identical & & \\
\hline \multirow[t]{4}{*}{ MO 96} & C2Of & gi|60360958|dbj|AB200364.1] & $139-538$ & $100 \%$ \\
\hline & C2Or & gi $|60360958| \mathrm{dbj}|\mathrm{AB} 200364.1|$ & $98-484$ & $100 \%$ \\
\hline & C21f & gi $60360958|\mathrm{dbj}| \mathrm{AB} 200364.1$ & $172-242$ & $100 \%$ \\
\hline & C21r & gi $|60360958| \mathrm{dbj} \mid \mathrm{AB} 200364.1$ & $98-517$ & $100 \%$ \\
\hline
\end{tabular}


Table 21: Sequence identity rate of PCR products of type D samples

\begin{tabular}{|c|c|c|c|c|}
\hline Name & Samples & Ref. No. GenBank & Position & Identical rate \\
\hline \multirow[t]{4}{*}{ MO 90} & D1f & gil260238|gb|S49407.1 & $254-696$ & $100 \%$ \\
\hline & D1r & gi|260238|gb|S49407.1 & $224-677$ & $100 \%$ \\
\hline & D2f & gi|260238|gb|S49407.1 & 254-709 & $100 \%$ \\
\hline & $\mathrm{D} 2 \mathrm{r}$ & gi|260238|gb|S49407.1 & $225-677$ & $100 \%$ \\
\hline \multirow[t]{2}{*}{ MO 91} & D3f & gi|260238|gb|S49407.1 & $254-696$ & $100 \%$ \\
\hline & D3r & gi|260238|gb|S49407.1 & $225-677$ & $100 \%$ \\
\hline \multirow[t]{4}{*}{ MO 92} & D4f & gi|260238|gb|S49407.1 & $270-709$ & $100 \%$ \\
\hline & D4r & gi|260238|gb|S49407.1 & $213-674$ & $99 \%$ \\
\hline & D5f & gi|260238|gb|S49407.1 & $259-696$ & $100 \%$ \\
\hline & D5r & gi|260238|gb|S49407.1 & $227-677$ & $100 \%$ \\
\hline \multirow[t]{4}{*}{ MO 93} & D6f & gi|260238|gb|S49407.1 & 281-709 & $100 \%$ \\
\hline & D6r & gi|260238|gb|S49407.1 & $213-639$ & $100 \%$ \\
\hline & D7f & gi|260238|gb|S49407.1 & $259-696$ & $100 \%$ \\
\hline & D7r & gi|260238|gb|S49407.1 & $225-677$ & $100 \%$ \\
\hline \multirow[t]{4}{*}{ MO 94} & D8f & gi|260238|gb|S49407.1 & $259-703$ & $100 \%$ \\
\hline & D8r & gi|260238|gb|S49407.1 & $227-682$ & $100 \%$ \\
\hline & D9f & gi|260238|gb|S49407.1 & $270-696$ & $100 \%$ \\
\hline & D9r & gi|260238|gb|S49407.1 & $227-677$ & $100 \%$ \\
\hline \multirow[t]{4}{*}{ MO 95} & D10f & gil260238|gb|S49407.1 & $270-709$ & $100 \%$ \\
\hline & D10r & Bad sequence & & \\
\hline & D11f & gi|260238|gb|S49407.1] & $282-702$ & $100 \%$ \\
\hline & D11r & gi|260238|gb|S49407.1 & $225-682$ & $100 \%$ \\
\hline \multirow[t]{4}{*}{ MO 96} & $\mathrm{D} 12 \mathrm{f}$ & gi|260238|gb|S49407.1 & $400-699$ & $100 \%$ \\
\hline & $\mathrm{D} 12 \mathrm{r}$ & Bad sequence & & \\
\hline & D13f & gi|260238|gb|S49407.1] & $254-696$ & $100 \%$ \\
\hline & $\mathrm{D} 13 \mathrm{r}$ & gi|260238|gb|S49407.1 & $227-677$ & $100 \%$ \\
\hline
\end{tabular}


Table 22a: Sequence identity rate of PCR products of type E samples

\begin{tabular}{|c|c|c|c|c|}
\hline Name & Samples & Ref. No. GenBank & Position & $\begin{array}{l}\text { Identical } \\
\text { rate }\end{array}$ \\
\hline \multirow[t]{4}{*}{ VR 34} & E1f & gi|40393|emb|X62089.1|CBNEUTOXE & $430-773$ & $100 \%$ \\
\hline & E1r & gi|40393|emb|X62089.1|CBNEUTOXE & $384-727$ & $100 \%$ \\
\hline & E2f & gi|40393|emb|X62089.1|CBNEUTOXE & nd & \\
\hline & $E 2 r$ & gi|40393|emb|X62089.1|CBNEUTOXE & nd & \\
\hline \multirow[t]{4}{*}{ VR 35} & E3f & gi|40393|emb|X62089.1|CBNEUTOXE & 414-773 & $100 \%$ \\
\hline & E3r & gi|40393|emb|X62089.1|CBNEUTOXE & $390-749$ & $100 \%$ \\
\hline & E4f & gi|40393|emb|X62089.1|CBNEUTOXE & $417-773$ & $100 \%$ \\
\hline & E4r & gi|40393|emb|X62089.1|CBNEUTOXE & $384-673$ & $100 \%$ \\
\hline \multirow[t]{2}{*}{ VR 37} & E5f & gi|40393|emb|X62089.1|CBNEUTOXE & $438-773$ & $99 \%$ \\
\hline & E5r & gi|40393|emb|X62089.1|CBNEUTOXE & $384-742$ & $99 \%$ \\
\hline \multirow[t]{2}{*}{ VR 38} & E6f & gi|40393|emb|X62089.1|CBNEUTOXE & 413-771 & $99 \%$ \\
\hline & E6r & gi|40393|emb|X62089.1|CBNEUTOXE & $390-732$ & $100 \%$ \\
\hline \multirow[t]{4}{*}{ VR 40} & E7f & gi|40393|emb|X62089.1|CBNEUTOXE & 413-773 & $100 \%$ \\
\hline & E7r & gi|40393|emb|X62089.1|CBNEUTOXE & 384-751 & $99 \%$ \\
\hline & E8f & gi|40393|emb|X62089.1|CBNEUTOXE & 413-773 & $100 \%$ \\
\hline & E8r & gi|40393|emb|X62089.1|CBNEUTOXE & $390-738$ & $100 \%$ \\
\hline \multirow[t]{4}{*}{ G 25} & E9f & emb|X62089.1|CBNEUTOXE & nd & \\
\hline & E9r & gi|40393|emb|X62089.1|CBNEUTOXE & nd & \\
\hline & E10f & gi|40393|emb|X62089.1|CBNEUTOXE & $467-773$ & $100 \%$ \\
\hline & E10r & gi|40393|emb|X62089.1|CBNEUTOXE & $384-701$ & $99 \%$ \\
\hline \multirow[t]{4}{*}{ G 27} & E11f & Bad sequence & & \\
\hline & E11r & Bad sec & & \\
\hline & E12f & emb|X62089.1|CBNEUTOXE & $513-773$ & $99 \%$ \\
\hline & E12r & gi|40393|emb|X6208 & $387-691$ & $99 \%$ \\
\hline \multirow[t]{4}{*}{ NF 14} & E13f & gi|40393|emb|X62089.1|CBNEUTOXE & $452-773$ & $100 \%$ \\
\hline & E13r & gi|40393|emb|X62089.1|CBNEUTOXE & $386-701$ & $100 \%$ \\
\hline & E14f & gi|40393|emb|X62089.1|CBNEUTOXE & 497-773 & $100 \%$ \\
\hline & E14r & gi|40393|emb|X62089.1|CBNEUTOXE & 384-718 & $99 \%$ \\
\hline \multirow[t]{4}{*}{ NF 15} & E15f & gi|40393|emb|X62089.1|CBNEUTOXE & $447-773$ & $99 \%$ \\
\hline & E15r & gi|40393|emb|X62089.1|CBNEUTOXE & 418-691 & $99 \%$ \\
\hline & E16f & gi|40393|emb|X62089.1|CBNEUTOXE & $427-773$ & $100 \%$ \\
\hline & E16r & gi|40393|emb|X62089.1|CBNEUTOXE & $384-720$ & $100 \%$ \\
\hline \multirow[t]{4}{*}{ NF 16} & E17f & gi|40393|emb|X62089.1|CBNEUTOXE & $447-773$ & $100 \%$ \\
\hline & E17r & gi|40393|emb|X62089.1|CBNEUTOXE & 384-719 & $100 \%$ \\
\hline & E18f & gi|40393|emb|X62089.1|CBNEUTOXE & $448-773$ & $99 \%$ \\
\hline & E18r & gi|40393|emb|X62089.1|CBNEUTOXE & 384-654 & $100 \%$ \\
\hline \multirow[t]{4}{*}{ NF 19} & E19f & Bad sequence & & \\
\hline & E19r & gi|40393|emb|X62089.1|CBNEU & 702 & $100 \%$ \\
\hline & E20f & gi|40393|emb|X62089.1|CBNEUTOXE & $449-773$ & $100 \%$ \\
\hline & E20r & gi|40393|emb|X62089.1|CBNEUTOXE & 384-719 & $100 \%$ \\
\hline \multirow[t]{4}{*}{ NF 23} & E21f & gi|40393|emb|X62089.1|CBNEUTOXE & $449-773$ & $99 \%$ \\
\hline & E21r & gi|40393|emb|X62089.1|CBNEUTOXE & $384-695$ & $99 \%$ \\
\hline & E22f & gi|40393|emb|X62089.1|CBNEUTOXE & $438-773$ & $100 \%$ \\
\hline & $E 22 r$ & gi|40393|emb|X62089.1|CBNEUTOXE & $384-711$ & $100 \%$ \\
\hline
\end{tabular}


Table 22b: Sequence identity rate of PCR products of type E samples (cont.)

\begin{tabular}{lcccc}
\hline Name & Samples & Ref. No. GenBank & Position & $\begin{array}{c}\text { Identical } \\
\text { rate }\end{array}$ \\
\hline NF 25 & E23f & gi|40393|emb|X62089.1|CBNEUTOXE & $427-773$ & $99 \%$ \\
& E23r & gi|40393|emb|X62089.1|CBNEUTOXE & $384-731$ & $100 \%$ \\
& E24f & gi|40393|emb|X62089.1|CBNEUTOXE & $446-773$ & $100 \%$ \\
& E24r & gi|40393|emb|X62089.1|CBNEUTOXE & $387-717$ & $100 \%$ \\
\hline
\end{tabular}

Table 23: Sequence identity rate of PCR products of type F samples

\begin{tabular}{lccrr}
\hline Name & Samples & Ref. No. GenBank & Position & $\begin{array}{c}\text { Identical } \\
\text { rate }\end{array}$ \\
\hline VR 34 & F1f & gi|529982|gb|L35496.1|CLOBONT & $390-908$ & $100 \%$ \\
& F1r & gi|529982|gb|L35496.1|CLOBONT & $366-884$ & $100 \%$ \\
VR 35 & F2f & gi|529982|gb|L35496.1|CLOBONT & $390-908$ & $100 \%$ \\
& F2r & gi|529982|gb|L35496.1|CLOBONT & $366-861$ & $99 \%$ \\
VR 40 & F3f & gi|529982|gb|L35496.1|CLOBONT & $390-908$ & $99 \%$ \\
& F3r & gi|529982|gb|L35496.1|CLOBONT & $686-839$ & $90 \%$ \\
& F4f & gi|529982|gb|L35496.1|CLOBONT & $394-908$ & $98 \%$ \\
& F4r & gi|529982|gb|L35496.1|CLOBONT & $378-837$ & $99 \%$ \\
\hline
\end{tabular}

\subsection{Staining solutions and procedures}

Modified Gram stain (Hucker's modification)

Solution 1 consists of a) $20.0 \mathrm{~g}$ crystal violet $200 \mathrm{~mL}$ ethanol (96-99\%)

b) $8 \mathrm{~g}$ ammonium oxalate

$800 \mathrm{~mL}$ demineralised water

Solution 2: $5 \mathrm{~g}$ iodine

$10 \mathrm{~g} \mathrm{KI}$

$1 \mathrm{~L}$ demineralised water

Solution 3: $200 \mathrm{ml}$ acetone

$250 \mathrm{~mL}$ ethanol

Solution 4: $20 \mathrm{~mL}$ Ziel-Neelsen carbol fuchsin

$180 \mathrm{~mL}$ demineralised water 


\section{Method}

First, an inoculum is taken from a culture using an inoculation loop and put on a clean microscope slide, and then allowed to air dry to produce a sparse single layer of bacteria. If the culture is solid, it is diluted and well mixed with a drop of sterile water on the slide. The air-dried smears are heat-fixed by passing the slide, inoculum side up, through a bunsen flame 1-2 times, without allowing the slide to become hot to the touch, stained by solution 1 (primary stain) for $30-90 \mathrm{~s}$, and then rinsed off with water for a maximum of five seconds. Lugol's iodine (solution 2) is added as a mordant for 60-120 s and then rinsed with water. Solution 3 is added as a decolourising agent, and the smear is rinsed with water immediately to prevent over-decolourisation. Then solution 4 is added as a counter stain. The smear is washed, air-dried, and examined under a microscope with an oil immersion lens. Gram positive bacteria are black-blue or purple, and the Gram negative bacteria are pinkish-red.

\section{Spore stain (Schaeffer-Fulton stain) Staining procedure}

A smear is prepared following the steps described in the Gram staining. The airdried, heat-fixed smear is flooded with $0.5 \%(\mathrm{w} / \mathrm{v})$ malachite green and heated on a flame to near-boiling for $5 \mathrm{~min}$. The smear is then rinsed in running water, counterstained with safranin ( $0.5 \%$ aqueous) for $30 \mathrm{~s}$, and air-dried. Being inspected under a microscope, endospores stain green, while vegetative cells pinkish-red. 


\section{ACKNOWLEDGEMENTS}

I would like to acknowledge my greatest debt to Professor Dr. Dr. Helge Böhnel, the director of the Institute of Tropical Animal Health and Institute of Applied Biotechnology, University of Göttingen, for accepting me as a Ph.D student. I have received inspiring supervision, encouragement, understanding, patience, and unfailing kindness throughout this study.

I would like to thank Prof. Dr. Dr. Udo ter Meulen for accepting to be my coreferee and his recommendation letters for my scholarship applications. I am particularly grateful to Dr. Frank Gessler for his ongoing immensely helpful comments, criticisms, discussions, and suggestions. This was especially for the practical and theoretical aspects during the study and for his critical reading of the thesis.

We would also like to thank Prof. Dr. Dr. Bertram Brenig, the director of the Institute of Veterinary Medicine, Georg-August-University Göttingen, for his approval for the DNA sequencing analyses at the institute. Thanks are extended to PD Dr. sc. agr. Christoph Knorr and Viola Raupach for their useful guidance and support in DNA sequencing and analyses.

We are grateful to Christian Wagner, Michaela Schmidt, Katrin Hampe and Deborah Fischer, the staff members of the Institute of Tropical Animal Health and Institute of Applied Biotechnology, University of Göttingen, for their co-operation and technical assistance.

Thanks are also due to Dr. Anke Grosse-Herrenthey, Dagmar Nölkes, Dr. Sibylle Pagel-Wieder, Kamal Eldin Hassan Ali Eltom, Dr. Elhassan Mohammed Ali Saeed, Aung Aung, Sibylle Reinmuth, Dr. Abdulkhalig Babiker, and Heinz Hunfeld for help, co-operation, critical suggestions, and the pleasant working atmosphere.

I am grateful to Antje Clarke, the former institute's secretary, for her 
encouragement and help in all aspects. I also thank Ursula Otto for her assistance and sympathy.

I am deeply indebted to Dr. Keith Wing Shing who unconditionally and enthusiastically took time from his busy schedule to proof read the manuscripts of this thesis and to give me valuable advice and encouragement.

Particular acknowledgments go to MSc. Tang Thi Kim Hong, Nguyen Minh Hien, and Le Huu Ngoc for helping me collect and sub-sample the honey and infant foods. I would like to take this opportunity to thank all my friends for helping me, for sharing enjoyable times, and for encouraging me throughout the study, especially during the hardest time after my father's death.

I wish to express my deepest appreciation to my family including my father, my mother and my sister for love, unfailing support and encouragement. Sadly, my father could not see the completion of my Ph.D. work.

I would like to gratefully acknowledge financial support for my Ph.D. study from Friedrich-Ebert-Stiftung and the Institute of Applied Biotechnology, GeorgAugust-University of Göttingen. The completion of this study would not have been possible without this invaluable support. I gratefully acknowledge the International Ph.D. Programme of Agricultural Sciences (IPAG) for accepting me to attend this programme. 


\section{CURRICULUM VITAE}

Name Thi Lam An, VU

Date of birth 23.09.1970

Place of birth Hanoi, Vietnam

Nationality Vietnamese

Marital status Single

\section{School education}

1976-1981 Primary school (Hanoi, Vietnam)

1981-1985 Intermediate school (Ho Chi Minh City, Vietnam)

1985-1988 High school (Ho Chi Minh City, Vietnam)

\section{University education}

1988-1992

University of Agriculture and Forestry, Ho Chi Minh City,

Vietnam

Diploma of University Degree (Veterinarian)

1999 -2002 Georg-August-University Göttingen, Germany

Master degree in agricultural sciences

2003-2006 Ph.D. student at the Institute of Agronomy and Animal

Production in the Tropics and Subtropics,

Georg-August-University Göttingen, Germany

\section{Employment}

1994 -1996 Assistant lecturer, Department of Microbiology, Parasitology, and Infectious Diseases, Faculty of Animal Science and Veterinary Medicine, University of Agriculture and Forestry, Ho Chi Minh City, Vietnam

1997-1999 Assistant lecturer in General Microbiology and Food Microbiology, Department of Food Microbiology, Faculty of Food Technology, University of Agriculture and Forestry, Ho Chi Minh City, Vietnam 